DANUZA SGOBBI SAES

\title{
ADOLESCENTES INFRATORES:
}

\section{UM ESTUDO COMPREENSIVO}

São Paulo

2003 
DANUZA SGOBBI SAES

ADOLESCENTES INFRATORES:

UM ESTUDO COMPREENSIVO

Dissertação apresentada ao Instituto de Psicologia da Universidade de São Paulo como parte dos requisitos para obtenção do título de Mestre.

Área de concentração: Psicologia Clínica.

Orientador: Prof ${ }^{\circ}$ Dra Leila S. Cury Tardivo.

São Paulo

2003 
Ficha Catalográfica preparada pelo Serviço de Biblioteca

e Documentação do Instituto de Psicologia da USP

Saes, D. S.

Adolescentes infratores: um estudo compreensivo./ Danuza Sgobbi Saes. - São Paulo: s.n., 2003. - 191p.

Dissertação (mestrado) - Instituto de Psicologia da Universidade de São Paulo. Departamento de Psicologia Clínica.

Orientadora: Leila S. Cury Tardivo.

1. Psicodiagnóstico 2. Adolescentes 3. Delinqüência juvenil 4. Desiderativo 5. Procedimento de desenhos-estórias I.Título 


\title{
ADOLESCENTES INFRATORES:
}

\section{UM ESTUDO COMPREENSIVO}

\author{
Danuza Sgobbi Saes
}

\section{BANCA EXAMINADORA:}

Yvette Piha Lehmann

José Tolentino Rosa

Leila S. Cury Tardivo

Dissertação defendida e aprovada em: xx/xx/xxxx. 


\section{AGRADECIMENTOS}

Aos meus pais pelo que são, por tudo que me deram e fizeram por mim. Eles são os maiores responsáveis pela concretização deste trabalho e pelo que realizei até hoje.

À minha Orientadora Prof ${ }^{a}$ Leila S. C. Tardivo, pela oportunidade, aprendizado e compreensão.

Aos Professores: José Tolentino Rosa e Yvette Piha, pelas valiosas contribuições.

À equipe L.A. - UNAS, que recebeu minha presença e pesquisa com carinho e respeito: Tamara, Antônia, Shirlei, Gedalva, Genário, Paula e Lise.

Às pessoas muito especiais que contribuíram para a realização deste trabalho de várias formas: Dayse Alessandra Canteiro Saes, Karina Kill, Mauro Cavaliere Ribeiro Sodré, Alexandro Sgobb Saes e Vagner Ferreira Vicente, Gabriel Braidatto.

A todos os adolescentes que fizeram parte deste estudo, contribuindo com a melhor parte dele. 
Não vou me adaptar

Eu não caibo mais nas roupas que eu cabia,

Eu não encho mais a casa de alegria.

Os anos se passaram enquanto eu dormia,

E quem eu queria bem me esquecia.

Será que eu falei o que ninguém ouvia?

Será que eu escutei o que ninguém dizia?

Eu não vou me adaptar.

Eu não tenho mais a cara que eu tinha,

No espelho essa cara não é minha.

Mas é que quando eu me toquei achei estranho,

A minha barba estava deste tamanho.

Será que eu falei o que ninguém dizia?

Será que eu escutei o que ninguém ouvia?

Eu não vou me adaptar.

Arnaldo Antunes 


\section{SUMÁRIO}

Apresentação

Resumo $\quad$ iii

Abstract $\quad$ v

1 - INTRODUÇÃO

1.1 Considerações acerca do Psicodiagnóstico 2

1.22 Teorias Psicanalíticas do Desenvolvimento Psíquico $\quad 8$

1.3 Aportes da Psicanálise para o Entendimento da Delinqüência 18

1.4 A Adolescência $\quad 29$

1.5 Adolescência e Delinqüência 38

1.6 O Atendimento ao Adolescente Infrator no Brasil 52

2- JUSTIFICATIVAS E OBJETIVOS

3-MÉTODO

3.1 Método Qualitativo e a Utilização do Estudo de Caso 64

3.2 Descrição dos Sujeitos $\quad 65$

$\begin{array}{ll}3.3 \text { Procedimentos } & 66\end{array}$

3.4 Aspectos Éticos $\quad 67$

3.5 Instrumentos Utilizados na Pesquisa 68

3.6 A Entrevista Clínica 68

3.7 O Questionário Desiderativo 70

$\begin{array}{ll}3.8 \text { Procedimentos de Desenhos-Estórias } & 71\end{array}$ 
7.3 - Autorização da Instituição 177

8- REFERÊNCIAS BIBLIOGRÁFICAS $\quad 180$ 


\section{LISTA DE FIGURAS}

$\begin{array}{ll}\text { Desenho } 1 \text { (Paulo) } & 78\end{array}$

$\begin{array}{ll}\text { Desenho } 2 \text { (Paulo) } & 79\end{array}$

$\begin{array}{ll}\text { Desenho } 3 \text { (Paulo) } & 80\end{array}$

$\begin{array}{ll}\text { Desenho } 4 \text { (Paulo) } & 81\end{array}$

$\begin{array}{ll}\text { Desenho } 5 \text { (Paulo) } & 82\end{array}$

$\begin{array}{ll}\text { Desenho } 1 \text { (Tiago) } & 90\end{array}$

$\begin{array}{ll}\text { Desenho } 2 \text { (Tiago) } & 91\end{array}$

$\begin{array}{ll}\text { Desenho } 3 \text { (Tiago) } & 92\end{array}$

$\begin{array}{ll}\text { Desenho } 4 \text { (Tiago) } & 93\end{array}$

$\begin{array}{ll}\text { Desenho } 5 \text { (Tiago) } & 94\end{array}$

$\begin{array}{ll}\text { Desenho } 1 \text { (João) } & 103\end{array}$

$\begin{array}{ll}\text { Desenho 1(Mateus) } & 110\end{array}$

$\begin{array}{ll}\text { Desenho } 2 \text { (Mateus) } & 111\end{array}$

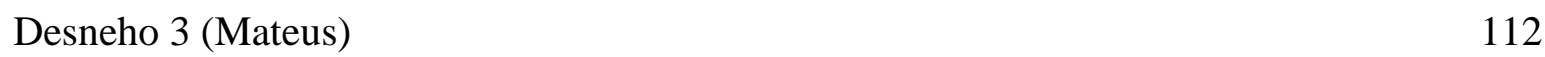

$\begin{array}{ll}\text { Desenho } 1 \text { (Lucas) } & 120\end{array}$

$\begin{array}{ll}\text { Desenho } 2 \text { (Lucas) } & 121\end{array}$

Desenho 3 (Lucas) 122

Desenho 4 (Lucas) 123

$\begin{array}{ll}\text { Desenho } 5 \text { (Lucas) } & 124\end{array}$

$\begin{array}{ll}\text { Desenho } 1 \text { (Marcos) } & 132\end{array}$ 
$\begin{array}{ll}\text { Desenho } 2 \text { (Marcos) } & 133\end{array}$

$\begin{array}{ll}\text { Desenho } 3 \text { (Marcos) } & 134\end{array}$

$\begin{array}{ll}\text { Desenho } 4 \text { (Marcos) } & 136\end{array}$

$\begin{array}{ll}\text { Desenho } 5 \text { (Marcos) } & 137\end{array}$

$\begin{array}{ll}\text { Desenho } 1 \text { (Pedro) } & 145\end{array}$

$\begin{array}{ll}\text { Desenho } 2 \text { (Pedro) } & 146\end{array}$

$\begin{array}{ll}\text { Desenho } 1 \text { (André) } & 154\end{array}$

Desenho 2 (André) 156

Desenho 3 (André) 158 


\section{Lista de Tabelas}

1 - Tabela do Perfil de Adolescentes atendidos pelo Ministério Público de São Paulo, no período de Julho de 1998 a Junho de 2001.

2 - Tabela de infrações cometidas pelos adolescentes atendidos no ministério público de são Paulo, no período de Julho de 1998 a Junho de 2001. 



\section{APRESENTAÇÃo}

Diariamente somos assolados por notícias as mais diversas, sobre violência e criminalidade urbana, sendo que grande parte destas envolve, de alguma forma, jovens.

Constatamos, através de diversas fontes de pesquisa, uma diminuição da idade dos jovens que cometem atos infracionais e um aumento da gravidade destes.

A criminalidade juvenil toma proporções assustadoras, parecendo muitas vezes uma questão sem solução.

O jovem, usado pela mídia como agente de consumo, passou a ser tratado por esta como um problema para a sociedade e assunto de segurança nacional.

Devemos considerar que ocorreram muitos avanços no Brasil com relação ao adolescente infrator e a seu atendimento, mas, na verdade, há muito caminho a se trilhar na compreensão desse problema e na intervenção sobre ele.

Os jovens são vítimas e agentes do crime, conseqüentemente, da violência, dor e sofrimento.

A violência e criminalidade são fenômenos relacionados a diversos fatores, tais como: educação, oportunidades, sistema legal, desigualdade social, valores culturais, valores ideológicos, ambientes sócio familiares e características psíquicas. 
Trata - se, portanto, de questões que exigem em seu enfrentamento esforços combinados por diversas áreas de conhecimento e atuação, buscando-se uma visão integrada, globalizada e uma responsabilidade individual, coletiva, científica e social.

Enquanto profissionais de Psicologia, interessados no sofrimento psíquico e na natureza humana, é incontestável a relevância de nossa participação, buscando uma compreensão mais profunda do psiquismo desses jovens.

Abandonando posturas estigmatizantes e moralizantes e enfatizando-se que o melhor instrumental de que dispomos é o conhecimento teórico e técnico.

A vertente clínica da Psicologia e um Psicodiagnóstico bem instrumentalizado, resgatando a subjetividade de cada ser envolvido e retomando o foco para questões de natureza psíquica, podem propor formas de enfrentamento em nível preventivo ou interventor, individual ou coletivo.

Consideramos que, além disso, o Psicodiagnóstico nos traz um novo olhar sobre aquele que cometeu o ato infracional, resgatando seus aspectos sadios, potencialidade e, por outro lado, nos aproxima deles, pois nos lembra de que temos também em nós muito do que neles se apresenta. 


\section{RESUMO}

SAES, S. D. Adolescentes Infratorel: Um Estudo compreensivo. São Paulo, 2003. 193 p. Dissertação de Mestrado. Instituto de Psicologia. Universidade de São Paulo.

Acreditamos na necessária contribuição da presente pesquisa, tendo como objetivos a compreensão sobre o psiquismo do adolescente em conflito com a lei através da utilização de um modelo compreensivo de psicodiagnóstico.

Iniciamos nossa reflexão com questões referentes ao psicodiagnóstico, remontando a sua construção histórica que lançou as bases para o referencial do Psicodiagnóstico Compreensivo.

Fizemos um esboço de teorias Psicanalíticas relevantes utilizando autores que são referenciais nesse tipo de psicodiagnóstico, a saber: Freud, Melanie Klein e Winnicott e através destes autores buscamos uma elucidação psicanalítica sobre o comportamento delinqüente.

Buscamos a compreensão sobre o fenômeno da adolescência abordando aspectos de ordem biológica, cultural, social e psicológica e relacionamos estas com a delinqüência através de pesquisas mais recentes de âmbito nacional que são contribuições importantes frente à nossa realidade.

Trouxemos um histórico do atendimento ao adolescente infrator no Brasil, no sentido de nos situarmos historicamente e entender o lócus em que se dará o estudo. 
A pesquisa realizada envolveu oito adolescentes, com idade de 14 a 16 anos, que se encontravam em cumprimento de medida de Liberdade Assistida por Roubo, no período de janeiro a agosto do ano de 2003.

A realização do psicodiagnóstico se deu através da inserção desses adolescentes em acompanhamento psicoterapêutico realizado pela autora, enquanto psicóloga pesquisadora em uma entidade não governamental conveniada à Fundação Estadual para o Bem Estar do Menor (FEBEM - SP).

Realizamos entrevistas com os adolescentes e, quando possível, com seus responsáveis e utilizamos as seguintes técnicas projetivas: O Questionário Desiderativo e o Procedimento de Desenhos - Estórias.

Utilizando o material recolhido durante o processo psicodiagnóstico, percebemos a importância deste na compreensão da infração dentro da constituição histórica de cada sujeito, bem como, no estabelecimento de medidas adequadas na condução de cada caso e na compreensão do fenômeno.da delinqüência juvenil.

Palavras-chave: Psicodiagnóstico, Adolescente, Infrator, Delinqüência, Desiderativo. 


\begin{abstract}
We do believe in the very necessary contribution of the present study, which aims at adolescents' psyche understanding that is in conflict with Law bay means of an understanding model of Psychodiagnosis.

In order to try to understand the emotional experience of each person concerning his uniqueness and to evaluate the importance of this study in establishing interventional and preventing strategies our reflection has been started with questions related to Psychodiagnosis that have remodeled its historical construction, which started the basis to Understanding Psychodiagnosis.

We have made a research of psychoanalytic theories referring to authors that are references in this kind of psychological, such as Freud, Melanie Klein and Winnicott and through those authors we have searched a psychoanalytic clarification about delinquent behavior.

We have tried to understand the phenomenon of adolescence by approaching biological, cultural, social and psychological aspects and crossed these ones to delinquency by means of the latest nationwide researches, which are important contributions to our reality.

We have brought the history of young delinquent assistance in Brazil in order to place us historically and understand the locus in which the study will occur.

The research has analyzed eight adolescents whose ages ranged from 14 to 16 years old, who had been accomplishing Assisted Freedom for Robbery from January to August of 2003.
\end{abstract}


The accomplishment of Psychodiagnosis happened due to their insertion into psychotherapeutical follow-up performed by author _ a research psychologist working in a non-governmental entity united to FEBEM-SP.

We have interviewed adolescents and, as possible, his responsible people and also used projection techniques: Desiderative Questionnaire and Drawing-Story Procedure.

Psychodiagnosis has been accomplished through and understanding point, in which we have searched an overview of data that have been obtained and interpreted based on Psychoanalytic Theory.

Making use of only our collected material during the psychodiagnosis process we could realize its importance by understanding the infraction inside the historical constitution of each person as well as the search of its uniqueness and establishment of suitable measures to conduct each case.

Key words: Psychodiagnosis, adolescent, delinquent, delinquency, Psychoanalysis. 


\section{1 - INTRODUÇÃO}

O principal objetivo desta unidade é trazer o corpo teórico em que o trabalho irá se desenvolver; para tanto, trazemos um resumo das pesquisas bibliográficas realizadas a respeito do tema principal.

Assim, lançamos as bases teóricas do Psicodiagnóstico Compreensivo e apontamos as características dos instrumentos que podem compor este processo fazendo uma análise e conclusão sobre sua importância para a avaliação global da personalidade.

Buscamos uma breve elucidação de três das correntes de pensamento da Psicanálise que tiveram fundamental importância na constituição das bases teóricas desse tipo de processo psicodiagnóstico e também na contribuição para um melhor entendimento sobre o desenvolvimento psíquico.

Passamos então a analisar fontes teóricas a respeito do fenômeno adolescente em seus aspectos biológicos, sociais e principalmente psíquicos.

Em relação à delinqüência, buscamos contribuições psicanalíticas utilizando as mesmas teorias anteriormente estudadas.

Relacionamos a adolescência e a delinqüência, citando pesquisas mais recentes realizadas em âmbito nacional. 
Finalizando esta unidade, buscamos situar o histórico do atendimento ao adolescente infrator no Brasil a fim de compreender a atual situação.

\section{1 - Considerações acerca do Psicodiagnóstico}

A avaliação psicológica é função privativa do psicólogo, definida pela lei 4119 de 27/08/1962, conforme o código de ética da profissão. Encontramos, porém, diferentes modos de fazê-la.

Estas diferenças se dão porque as ciências constróem um modo específico de apreender os fatos que se propõem a explicar através de suas formulações conceituais.

Assim, cada escola de pensamento construiu seu método de acordo com as idéias que desenvolvia acerca de seu objeto, do processo de conhecimento e de sua concepção sobre ciência. (Jupiassu, 1989; Rappaport, 1982)

No decorrer do desenvolvimento das ciências da mente, percebemos a construção de diversos paradigmas a esse respeito.

O desenvolvimento da Psicologia enquanto ciência não foi linear, desenvolveu-se com uma profusão de diferentes interpretações a que ela se propunha. (Fiqueiredo, 1996)

A avaliação psicológica pode ser considerada de diversas formas conforme a escola de pensamento em que assenta sua realização.

Ela pode estar inserida em um processo psicodiagnóstico, isto é, em um contexto de conhecimento dos fenômenos psíquicos.

Podemos considerar que o Psicodiagnóstico implica a compreensão de um fenômeno, utilizando-se para tanto estratégias específicas de avaliação de caráter 
qualitativo ou quantitativo, com objetivos baseados na compreensão dos fenômenos relacionados a aspectos mentais, emocionais e comportamentais humanos (Cunha, 2000).

Neste processo deparamo-nos não apenas com as diferenças relativas às escolas teóricas, como também com questões do problema a ser estudado e do contexto em que estão inseridos. Esses dados acabam por determinar sua estruturação do processo.

Com o nascimento da Psicanálise, estabelece-se um novo paradigma sobre o homem, sobre a ciência, sobre o método de pesquisa, sobre os fenômenos humanos e, consequentemente, sobre a realização do Psicodiagnóstico (Capitão, 1999).

Freud, estudando empiricamente os processos inconscientes através dos pacientes que atendia, desenvolveu vários pressupostos teóricos em relação ao funcionamento normal ou patológico da mente, ao introduzir conceitos que dizem respeito a uma nova compreensão dos fenômenos psíquicos (Uchôa, 1984).

O fundamental, no que tange ao método, é que ele se preocupou em dar um estatuto de ciência à psicanálise através de uma constante reflexão metodológica e epistemológica.

Tanto no seu trabalho clínico como na compreensão do que se passava com o paciente e na tentativa de formular conceitos gerais sobre a mente (Capitão, 1999).

A Psicanálise solidificou-se e influenciou outras ciências através da proposta de um novo paradigma sobre ciência e comportamento, denunciando a relatividade do saber, a reciprocidade de influência entre observador e observado e o questionamento sobre a neutralidade e objetividade científica (Silva, 1993).

Assim, o processo diagnóstico em Psicologia não tem um caráter classificatório ou visa a trazer um aglomerado de dados e informes. Traz uma compreensão global da pessoa, sendo o mais importante neste processo a investigação de fenômenos intrapsíquicos, da estrutura e dinâmica da personalidade, incluindo aspectos psicodiagnósticos e prognósticos. 
Através de um referencial clínico, voltado para a elucidação do significado das perturbações, com ênfase na dinâmica emocional inconsciente (Tardivo, 2000; Trinca, 1984).

Dentro da escola psicodinâmica busca-se a identificação e compreensão de conflitos, mecanismos de defesa, estados emocionais, fantasias, traços de caráter, aspectos sadios e patológicos da personalidade (Arzeno, 1995).

Para tornar esse processo o mais fecundo e completo possível, muitos instrumentos foram sendo desenvolvidos, tais como entrevistas, testes e procedimentos.

Cada um desses instrumentos deve ser usado de forma complementar, estudando-se o paciente através de diversas vias de comunicação, adequando seu uso às características deste paciente e do problema a ser estudado (Cunha, 2000; Arzeno, 1995).

A entrevista é entendida como uma relação especial entre entrevistador e entrevistado, onde a relevância recai sobre as variáveis determinadas por este último. Tratase de uma forma de observação ampla que se apoia em uma concepção psicodinâmica da personalidade.

O conceito de teste projetivo, por sua vez, foi introduzido por Franck em 1939 para explicar a relação entre técnicas como o Rorschach, o teste de apercepção de palavras e o Tematic Aperception Test (TAT), que se caracterizam por uma ambigüidade do material e liberdade de resposta.

Na obra de Freud, encontramos a introdução deste conceito, em 1894, na explicação do mecanismo da neurose de angústia e, em 1896, analisando um caso de paranóia, onde ele afirma que a projeção consiste em atribuir impulsos e afetos indesejáveis ao mundo exterior como mecanismo de defesa. 
Em 1913, ele complementa que a projeção também ocorre quando não há conflito, sendo um mecanismo de defesa frente à ansiedade e também um mecanismo normal quando a percepção atual é influenciada por percepções anteriores.

No teste projetivo, o indivíduo fica livre para responder ou realizar a atividade, vale aquilo que lhe vem espontaneamente, com liberdade de tempo e de respostas.

Acontece uma estruturação inconsciente do material, uma síntese pessoal que expressa o modo como o paciente estabelece contato com a realidade interna e externa (Ocampo, 1981; Grassano, 1997).

Ocorre uma regressão a serviço do Ego, com a redução do controle há um movimento regressivo do processo secundário, princípio de realidade, para o processo primário, princípio de prazer, e a utilização de mecanismos comumente utilizados na elaboração onírica (Cunha, 2000).

Os estímulos representam objetos incompletos e as respostas são tentativas de dar forma, organização e sentido emocional. Assim, surgem impulsos reparadores, criativos ou hostis que possibilitam diferentes qualidades de produção.

Este processo permite ao psicólogo observar a capacidade para dar forma, organização e sentido emocional ao estímulo projetivo, avivando conflitos psíquicos, desencadeando angústia e regressão e a utilização de mecanismos de defesa.

Permitindo assim inferir como a personalidade está organizada em termos de ansiedades predominantes, mecanismos de defesa e relações de objeto e, portanto, um menor ou maior grau de patologia.

Trinca (1989, 1997), desenvolve uma concepção de psicodiagnóstico que tenta dar coerência à união entre o uso de entrevistas clínicas, técnicas projetivas e um conceito psicodinâmico da personalidade. 
Ele denomina compreensivo o psicodiagnóstico que possui um referencial clínico e é caracterizado por alguns fatores estruturantes, a saber:

- O objetivo de elucidar o significado das perturbações, ênfase na dinâmica emocional inconsciente, considerações de conjunto para o material clínico, busca de compreensão psicológica globalizada do paciente, seleção de aspectos centrais e nodais, predomínio do julgamento clínico, subordinação do processo diagnóstico ao pensamento clínico, prevalência do uso de métodos e técnicas fundamentados na associação livre.

O diagnóstico psicológico compreensivo tem se mostrado um recurso útil para:

- Avaliação global da personalidade, determinação da natureza, intensidade e relevância dos distúrbios, orientação psicológica ao paciente, pais, responsáveis, escola, fornecimento de subsídios aos demais profissionais, indicações ou encaminhamentos terapêuticos, definição do tipo de intervenção psicoterapêutica, determinação dos objetivos, áreas relevantes e intensidade da intervenção psicoterapêutica (planejamento psicoterapêutico), o prognóstico do caso e sua evolução terapêutica e pesquisa psicológica.

Os testes projetivos têm sido cada vez mais amplamente utilizados. Sá (1987), apresenta estudos sobre a reincidência criminal e características de personalidade a partir do Desenho da figura humana e do teste das pirâmides coloridas.

Carmo (1989) apresenta um estudo que busca organizar modelos reduzidos de exame psicológico que forneçam os elementos indispensáveis para o estabelecimento do Psicodiagnóstico do tipo Compreensivo.

A pesquisa, de natureza qualitativa, analisou o conteúdo das anamneses e das interpretações de cada técnica e teste, comparando o conteúdo, a síntese final e o relato das interpretações de relatórios de exames psicológicos de crianças de seis a sete anos e onze meses de idade atendidas em uma clínica - escola. 
Este estudo concluiu que é possível organizar modelos reduzidos de psicodiagnósticos deste tipo sem a perda de validade.

Um exemplo de pesquisa realizada com o Psicodiagnóstico Compreensivo na área de adolescentes infratores é o estudo de Alves (2001), em que a autora utilizou esse recurso para estudar alterações na psicodinâmica de adolescentes privados de liberdade, verificando aspectos afetivo-emocionais destes, no início e após seis meses de internação na FEBEMSP.

Essa autora utilizou o Procedimento de Desenhos - Estórias e a entrevista Psicodiagnóstica com os adolescentes e com os pais.

Concluindo que a internação acarreta conseqüências como a utilização de mecanismos de defesa mais regredidos, um predomínio da pulsão de morte e um agravamento no estado emocional dos mesmos, bem como um empobrecimento das relações afetivas e sociais.

Consideramos, então, a viabilidade de utilização do referencial do Psicodiagnóstico Compreensivo não apenas com adolescentes, mas também com aqueles que cometeram atos infracionais, na investigação de processos intrapsíquicos, estabelecendo estratégias de ação. 


\section{2 - Teorias psicanalíticas do desenvolvimento psíquico}

É unânime, entre os teóricos psicodinâmicos, que cada etapa evolutiva do ciclo vital humano depende de aquisições de etapas anteriores. A tentativa de entendimento sobre o fenômeno da adolescência requer uma compreensão sobre as bases do desenvolvimento psíquico.

Em todas as obras dedicadas ao tema da adolescência, fica claro que, quando o indivíduo atinge esta fase, já vivenciou múltiplas e variadas experiências que caracterizarão o aparato psíquico que terá a seu dispor no enfrentamento das vicissitudes dessa fase e, consequentemente, o sucesso deste no alcance de uma identidade adulta mais saudável.

É necessário, portanto, que façamos um breve resumo sobre as teorias psicanalíticas de relevância, na compreensão do desenvolvimento do psiquismo humano, utilizando as obras de Freud, Melanie Klein e Winnicott.

Freud $(1900,1901,1910)$ lançou as bases para a compreensão do desenvolvimento do psiquismo humano, não necessariamente no atendimento à criança, apesar de o ter feito, como é o caso do 'Pequeno Hans' (1909), mas, no atendimento a pacientes adultos, onde através do trabalho psicanalítico foi percebendo a importância das experiências dos primeiros anos de vida na formação da personalidade do indivíduo.

A partir dos estudos de Freud e Breuer sobre a histeria, inicialmente tratada pelo método hipnótico, descobriu-se que a lembrança de um fato na infância, juntamente com todo o afeto correspondente, causava o desaparecimento dos sintomas. Assim, desde seus primeiros estudos, Freud volta a sua atenção para a história primitiva e o papel da sexualidade nos quadros patológicos e normais do indivíduo. 
Posteriormente, Freud detectou a inadequação do método hipnótico e propôs como alternativa o método da associação livre, em que o paciente era estimulado a falar livremente o que lhe vinha à mente. ()

A partir desse método, surgiram novos conceitos a serem acrescentados: recalque, quando fatos tornavam - se não acessíveis à consciência em razão de entrarem em conflito com a personalidade e resistência, a força que impede o acesso do fato à consciência. (Freud, 1900,1901,1910,1913,1920)

Foi compelido a compreender a significação da vida onírica dele e de seus pacientes e a relação dos sonhos trazidos por seus pacientes, conteúdo manifesto, e as forças inconscientes atuantes, conteúdo latente.

Em essência, o sonho seria a tentativa de realização de desejos reprimidos, já que a censura se afrouxa quando são cortadas as relações com a realidade. (Freud, 1900,1901,1910,1913,1920).

Este caminho permite a Freud estabelecer vários pressupostos teóricos, não só em relação ao funcionamento patológico, como também em relação à vida normal visando a compreensão dos fenômenos e funcionamento do aparelho psíquico.

Estabelece a divisão desse aparelho em instâncias, a saber: Id, Ego e Superego. Sendo o Id o reservatório de impulsos, o Ego nascido do contato deste com o meio, um regulador das funções adaptativas e o Superego, que surge da introjeção das figuras parentais, tendo função na formação da moral. (Laplanche; Pontalis, 1999).

Freud nos mostra a presença da sexualidade, desde o nascimento, como uma poderosa força instintiva em busca do prazer que chama de libido

Estabelece, a partir daí, as fases de desenvolvimento psicossexual, onde a libido desloca-se do objeto, isto é, da fonte de prazer, no decorrer do desenvolvimento psíquico e o Complexo de Édipo, onde a criança vivência desejos e fantasias de ordem sexual em relação a seus pais, sendo que o desfecho deste tem grande envolvimento no curso da vida psíquica. (Freud; 1900,1901,1910,1913,1920) 
Freud também propõe os conceitos de Narcisismo, em que a libido volta-se para o próprio Ego e das pulsões que inicialmente chamou de "pulsões de autoconservação e conservação da espécie” e, posteriormente, de “pulsões de vida e morte”. (Brenner, 1975; Uchôa, 1984; Nasio, 1995).

Na teoria dos instintos de vida e morte, a agressividade foi concebida como a deflexão dos instintos de morte para o exterior como algo essencial à natureza humana, ou então voltada para o próprio ego com o prazer do sofrimento (masoquismo).

O instinto foi concebido como algo dinâmico, como força biológica que busca objetos necessários à evolução e ao desenvolvimento da personalidade, radicando-se no biológico, mas não está preso ao objeto, desloca-se com a evolução.

A compreensão sobre o desenvolvimento psíquico obteve grande desenvolvimento com a contribuição posterior de Melanie Klein, pois esta introduziu o atendimento psicanalítico a crianças de forma muito específica:

Através de seu trabalho clínico desenvolveu uma teoria que se baseava, fundamentalmente, nas fantasias intrapsíquicas inconscientes, condensando o cronograma evolutivo da teoria clássica no primeiro ano de vida.

Gabbard (1998 p.45).

Embora, muito próxima da teoria clássica da psicanálise, Klein introduziu novos conceitos, modificou outros e, principalmente, introduzindo o que se pode chamar técnica lúdica, com crianças pequenas, isto é, utilização do jogo como forma diagnóstica e terapêutica na clínica destes, incorporando à clínica as teorias de Freud sobre “pulsões de vida e morte”.(Simon, 1986)

Concebendo a mente como um universo de objetos internos relacionados, trouxe portanto, grandes contribuições para a compreensão do relacionamento objetal. (Gabbard, 1998; Baranger, 1994). 
Simon (1986) ajuda a compreender a fundamental importância dada por ela à pulsão de morte. Klein propõe que esta causa um terror de aniquilamento no bebê e, para defender-se deste, o Ego sofre uma cisão.

Então, utilizando mecanismos de projeção e introjeção, separa os aspectos bons e maus dos objetos.

Assim, os conteúdos negativos percebidos nos objetos são projetados na mãe e, em conseqüência disto, surge uma ansiedade persecutória, já que a criança teme ataques desta. É a chamada posição esquizoparanóide.

Os ciclos de projeção e introjeção oscilam, até que a criança possa integrar os aspectos bons e maus dos objetos e entendê-los, como fazendo parte de um único objeto.

Após essa integração, preocupa-se com danos em que ela acredita ter causado ao objeto, surgindo a ansiedade característica da posição depressiva.

A criança tenta resolver a culpa por estes danos, através de um processo de reparação, em que ela tenta recompensar o objeto, através de atos de amor e criatividade (Klein; Riviére, 1970).

O conflito inconsciente, portanto, passa a ser compreendido não apenas como uma batalha entre um impulso e uma defesa, mas também, como um choque entre pares opostos de relações objetais internalizadas.

Posteriormente, Winnicott (2001) deu novas e importantes contribuições à teoria do desenvolvimento psíquico, estabelecendo um novo paradigma sobre a natureza humana.

Postula que faz parte da natureza humana uma tendência inata à integração e esta tendência só se torna um fato a partir de um ambiente facilitador. (Winnicott, 2000).

O processo de amadurecimento começa na gestação, o bebê tende a se integrar, isto é, chegar à manutenção de um estado de unidade, onde há a distinção entre eu e não - eu.

A integração significa responsabilidade, ao mesmo tempo em que consciência, um conjunto de memórias, e junção de passado, presente e futuro dentro de um relacionamento. 
(Winnicott, 2000. p.140).

Antes disso o bebê não tem um centro, não sabe da existência de um eu e um não-eu, do tempo e do espaço e tem experiências esparsas.

Neste estágio de não integração, o bebê apresenta também um impulso amoroso primitivo de qualidade destrutiva, ligado aos impulsos do Id, onde o amor é expresso fisicamente.

No entanto, esse estado não pode ser chamado de crueldade, pois está mais relacionado à motilidade, à voracidade e não há no bebê ainda, a percepção de destrutividade (Winnicott, 1975 p.122):

No princípio, o bebê é arrebatado por impulsos e só muito gradativamente chega à compreensão de que a coisa atacada numa excitada experiência de alimentação constitui uma parte vulnerável da mãe, o outro ser humano que é tão estimado como pessoa nos intervalos tranqüilos entre excitações e orgias.

Ao nascimento do bebê, a mãe mergulha em um estado de regressão partindo das suas experiências enquanto bebê. Esse estado proporciona tal fusão entre eles, que torna-se possível a ela compreender as necessidades de seu bebê.

Tal estado é chamado por Winnicott de preocupação materna primária. (Winnicott, 1990, 1999 e 2000). No processo de integração, o bebê passa por fases: dependência absoluta para com a mãe, até aproximadamente três meses, e dependência relativa, que ocorre aproximadamente até um ano. E, posteriormente a fase rumo à independência, esta indo até a morte, pois, o processo de integração é constante.

A passagem de uma fase à outra, coincidindo com o período em que a mãe vai gradualmente voltando-se novamente para si mesma, não causa danos ao desenvolvimento emocional da criança e ela vai se tornando habilitada a suportar as possíveis falhas do ambiente. 
Mas, se essas falhas acontecerem de forma a serem sentidas como invasões do ambiente ao seu Self, podem causar um estancamento em seu desenvolvimento emocional ou o surgimento de uma psicopatologia, sendo que, quanto mais precoces essas falhas, mais danosas podem ser.

Nas fases de dependência absoluta e relativa, o bebê tem tarefas a realizar, para que aconteça o seu amadurecimento. A mãe suficientemente boa é aquela que dá condições para que as tarefas se realizem.

Tudo que virá depois se assentará no modo como essas conquistas foram sendo realizadas, sendo elas: integração no espaço e tempo, o bebê torna-se apto para vivenciar subjetivamente o tempo e o espaço. Isso acontece através do contato com a mãe, os ritmos do seu corpo, a rotina confiável dos cuidados diários, a sustentação física do bebê, que Winnicott (xxxx), chama de holding, alojamento da psique no corpo. O corpo é essencial para a psique, já que esta surge da elaboração imaginativa das funções corpóreas, tornando-se assim possível a integração das experiências motoras e sensoriais.

A integração da psique ao soma tem a ver com o relacionamento da pessoa com o próprio corpo, é uma sensação de habitá-lo, é chamada personalização.

Início das relações objetais é o contato com a realidade, em que a mãe apresenta, constantemente e com regularidade, os objetos ao bebê, sempre de acordo com sua necessidade que é observada em seu gesto espontâneo.

Essa apresentação é feita de forma a lhe dar a ilusão de que criou o objeto que encontrou, dando origem à ilusão de onipotência.

Quando o bebê amadurece, descobre que não foi ele quem criou o objeto, mas o sentimento de que é possível criar permanece, dando origem à criatividade.

A ‘mãe suficientemente boa’ de Winnicott é uma mãe natural, uma pessoa comum que, através daquilo que ele denominou como preocupação materna primária, pode se adaptar às necessidades do bebê, oferecendo-lhe condições para cumprir as tarefas acima citadas:

O ‘segurar' pode ser feito, com sucesso, por alguém que não tenha o menor conhecimento intelectual daquilo que está ocorrendo com o indivíduo; o que se 
exige é a capacidade de se identificar de se perceber como o bebê está se sentindo.

(Winnicott, 1999. p 10).

A mãe suficientemente boa também não existe sem os outros. Ela não existe sem um corpo sociocultural, que lhe dê possibilidade de exercer suas funções. A boa maternagem, assim como suas falhas, tem origem na mãe, no pai, nos ancestrais, na situação social em que a mãe se encontra, nas características da sua cultura e de sua época. Trata-se de um fenômeno de grande complexidade.

(Safra, 1999. p.139).

Na fase da dependência relativa, surge o uso do objeto transicional, que é algo que substitui a mãe nos momentos de ansiedade, causados pela inserção no mundo real.

Seu surgimento está situado em um espaço intermediário entre o subjetivo e o real: o espaço potencial, onde há um descanso da eterna tarefa de diferenciar o real da fantasia.

É nesse mesmo espaço intermediário que se constitui o brincar e posteriormente as artes, a religião e os fenômenos culturais (Winnicott, 1975).

Chega, então, o momento em que a criança pode assumir a responsabilidade por seus instintos, pois, aprendeu a ter responsabilidade, originando - se assim, segundo Winnicott, o conceito de envolvimento.

O pai entra então como figura total, estabelecendo-se a relação triangular, que dará origem ao Complexo de Édipo, havendo uma diferenciação entre o eu e o não eu, isto é, o self está constituído:

Está na maneira como o homem organiza a sonoridade, o tempo, o espaço, o gesto, dentro da relação com outro significativo (...) Não se deve pensar no Self como uma organização mental, ou como uma representação de si mesmo, mas como o indivíduo organiza-se no tempo, no espaço, no gesto, a partir daí da sua corporeidade. O self se dá no corpo, o self é o corpo. 
(Safra, 1999. P.135).

O distúrbio psíquico é avaliado segundo o momento do desenvolvimento em que o ambiente falhou.

Falhas ambientais ocorridas na fase de dependência absoluta podem levar o indivíduo à construção de um falso Self e a uma psicose, que é o estancamento do processo de desenvolvimento (Dias, 1998).

Na fase de dependência relativa as falhas podem levar às depressões e paranóias, pois nesta fase o bebê tem de lidar com as tendências construtivas e destrutivas da própria natureza humana.

A falta de vínculos entre a psique e o soma, na fase de dependência absoluta, causa à despersonalização encontrada nas psicoses, já a dissociação ocorrida entre as fases de dependência absoluta e relativa leva a distúrbios psicossomáticos e o desenvolvimento da doença torna-se uma tentativa de cura dessa dissociação.

Após a integração, na fase rumo à independência, as falhas não são no âmbito das relações interpessoais e podem levar às neuroses.

Falhas no ambiente também podem levar à tendência anti-social que origina a delinqüência, podendo acontecer em neuróticos ou psicóticos tendo suas origens na privação ou deprivação, isto é, quando a criança é privada de um ambiente suficientemente bom ou o perde posteriormente:

Um distúrbio psicológico significa imaturidade do crescimento emocional do indivíduo, e esse crescimento inclui a evolução da capacidade do indivíduo de se relacionar com pessoas e com o ambiente de modo geral.

(Winnicott, 1999. p. 96). 
Winnicott (1990) enfatiza que o indivíduo saudável não é aquele apenas que possui ausência de doença psíquica, mas, sim, o indivíduo que tem um viver criativo, uma existência psicossomática.

O indivíduo que sente que a vida vale a pena ser vivida, pois, vive com autenticidade, de acordo com suas tendências inatas ou com potencialidades do seu Self, não deixando nunca de se desenvolver emocionalmente; o indivíduo que tem como prazeroso o uso do corpo e suas funções e que também é capaz de se sentir deprimido:

A vida de um indivíduo saudável é caracterizada por medos, sentimentos conflitivos, dúvidas, frustrações, tanto quanto por características positivas. O principal é que o homem ou a mulher sinta que estão vivendo sua própria vida, assumindo responsabilidade pela ação ou pela inatividade, e sejam capazes de assumir os aplausos pelo sucesso ou censura pelas falhas.

(Winnicott, 1999. p.10).

Com o estudo da teoria destes importantes autores, percebemos que a construção teórica de cada um deles vai diferenciando-se em aspectos importantes da metapsicologia.

Não cabe a este estudo um maior aprofundamento nestas comparações teóricas, mas, vale ressaltar que estas alterações se refletem, também, em aspectos como a compreensão sobre a adolescência e, principalmente, sobre o comportamento criminoso. 


\section{3 - Aportes da Psicanálise para o Entendimento da Delinqüência}

Diversos autores da Psicanálise fizeram importantes reflexões sobre o comportamento criminoso e sobre temas relacionados com a psicopatia e a agressividade.

Mesmo com diferentes denominações e concepções, é possível extrair importantes contribuições da Psicanálise.

Neste trabalho ressaltamos os estudos dos autores que usamos como referência: Freud, Melanie Klein e Winnicott.

Para Freud (1930), a agressividade está diretamente relacionada à pulsão de morte. Os dois tipos de pulsões nunca aparecem isolados, incidem nas relações de objeto consigo mesmo e entre as instâncias psíquicas.

Parte da pulsão de morte é voltada para o mundo externo e vem à tona como destrutividade, pois, assim, deixa de se voltar para o próprio Self aumentando a auto destrutividade. Quando a pulsão de morte é voltada para o exterior, Freud a denomina de pulsão de destruição (Freud, 1930).

Assim, a inclinação para a agressão é uma disposição instintiva, original e auto subsistente; não foi criada pela propriedade. Freud (1930) diz que os homens não são criaturas gentis que desejam apenas serem amadas e defendem-se quando atacados.

São criaturas que possuem grande parcela de agressividade, sendo assim capazes de atos cruéis contra seus semelhantes, que muitas vezes, são utilizados para satisfazer esta, a não ser que mecanismos contrários surjam e sejam acionados.

Essa inclinação se deve ao fato de que o sentimento de felicidade derivado da satisfação de um selvagem impulso instintivo é mais intenso do que aquele proporcionado por um impulso controlado. 
A agressão mútua, porém, leva a grande dispersão de energia no sentido de nos livrar da ameaça de desintegração da sociedade. Assim, o homem civilizado trocou uma parcela destas satisfações que geram felicidade pela segurança.

Desta forma, criou regras que servem para economizar energia quando decisões têm que ser tomadas; a ordem é uma exigência da civilização, isto é, sua primeira exigência é a justiça, a garantia de uma lei que não pode ser violada em favor de um indivíduo.

A necessidade de tornar a agressão inofensiva depende de um complexo mecanismo.

A agressividade é introjetada e assumida por uma parte do ego e o superego, sobre a forma de "consciência", volta-se contra o restante do ego e dá origem ao sentimento de culpa.

Assim, a consciência surge através da repressão de um impulso agressivo e é reforçada por novas repressões do mesmo tipo.

O sentimento de culpa surge com a definição de bom e mau. Essa definição, por sua vez, está atrelada à perda de amor e medo de punição, que fazem com que criaturas dependentes, como crianças, sintam-se ameaçadas.

Quando a autoridade é internalizada, a consciência atinge um estado mais elevado e passa a ser uma continuação da severidade externa, com componentes individuais.

Freud (1930) fez tentativas de compreensão do comportamento criminoso afirmando que há indivíduos que possuem um sentimento de culpa inconsciente, outros que não desenvolveram inibições morais e aqueles que acreditam ser justificada sua luta contra a sociedade. 
Ele ainda distingue os tipos libidinais, caracterizando o tipo narcisista como transgressivo às normas, não tendo tensão entre o ego e superego, com predominância das necessidades eróticas e orientação para a auto conservação.

Em relação aos destinos possíveis do narcisismo, o criminoso se aproxima de um quadro psicopático.

Klein também considera a agressão como manifestação da pulsão de morte e afirma que, se a agressão é pulsional, ela obedece à mutabilidade das pulsões e fundida com a pulsão de vida se volta para os objetos internos, externos ou o próprio Self. (Klein, 1927, 1933, 1934).

Quando a agressão se volta para objetos, há uma fantasia de ataque a estes, que levam a uma preocupação com as conseqüências negativas que fazem o indivíduo entrar em um estado paranóide, auto perpetuante.

A agressão, para Klein, é um fator decisivo no desenvolvimento mental, pois, na saúde, as pulsões de vida devem estar em ascendência; quando acontece o contrário, podem manifestar-se patologias ligadas à agressão e estas não seriam um resultado direto na frustração que a realidade impõe, pois dependem da subjetividade do sujeito. (Hinshelwood, 1992; Bleichmar,1992, Shine, 2001).

Klein traz importantes contribuições à compreensão do pensamento criminoso, principalmente através do trabalho clínico com crianças pequenas.

Ela afirma que é possível encontrar tendências criminais em ação com crianças normais e a que luta contra tendências anti-sociais inicia-se muito precocemente (Klein, 1927, 1933,1934). 
Toda a formação e dificuldades de caráter provêm do desenvolvimento edípico. Quando ele se instaura, no fim do primeiro e começo do segundo ano de vida, acham-se em plena ação os impulsos sádico orais e sádicos anais.

Esses impulsos, inicialmente, se voltam para os objetos dos quais se desenvolve o complexo: os pais. E depois, voltam-se para os irmãos maiores e menores.

As imagos são formadas concomitante ao momento em que a criança começa a realizar a primeira introjeção oral dos objetos, por isso, são dotadas de atributos sádicos.

A excessiva violência desta primeira etapa do superego se explica pelo fato de que ele é produto de instintos destrutivos que tem sua origem no instinto de morte, sofrendo uma fusão parcial com o instinto de vida.

Assim, os impulsos libidinais carregam consigo grandes quantidades de impulsos agressivos.

Quanto mais forte suas tendências agressivas, mais suas imagos parentais estarão revestidas de um caráter 'terrorífeco' causando-lhe terror em ser atacado por estes (Klein, 1927,1933,1934).

Os objetos internos passam a ser perigosos quando são revestidos destes impulsos sádicos e causam temor.

O temor leva a criança a fantasiar ataque dos objetos, contudo, estes objetos para os quais voltam seu ódio, também são objetos amados, o que leva ao desenvolvimento de conflitos e sentimentos de culpa.

Os impulsos agressivos são voltados contra os pais, são projetados sobre eles desenvolvendo imagens deformadas. As crianças se protegem dos ataques que imaginam que recebem, voltando ataques ainda mais violentos contra estes, proporcionando um incremento da angústia. 
Klein ainda afirma que nos casos em que não apenas na fantasia, como também na realidade, sofrem certo grau de perseguição por partes dos pais e crescem em um ambiente miserável, há um reforço das fantasias. (Klein, 1927, 1933,1934).

Se este ciclo não se rompe, o indivíduo continua sobre tensão destas angústias e retém os mecanismos de defesa deste estágio.

As crianças que mostram tendências associais ou criminais temem uma cruel retaliação de seus pais, como castigo de suas fantasias agressivas contra eles.

Os recalques mais profundos são dirigidos pelo superego contra as tendências antisociais que levam esta situação conflitante ao inconsciente, sendo o conflito o cerne das tendências criminais.

O superego dos criminosos é caraterizado por excessiva crueldade e severidade e, se o medo do superego ultrapassa certos limites, ele se sentirá compelido a destruir pessoas.

A tendência para o crime deriva de um superego que ocasiona a ansiedade e sentimento de culpa, pois há uma fixação em um estágio muito precoce.

Os atos dos criminosos buscam uma punição em razão desse sentimento de culpa recalcado muito forte e, ao mesmo tempo, precoce, impedindo a criança de elaborar suas fixações e sublimá-las.

Klein $(1927,1933,1934)$ justifica esta cadeia dizendo que as fantasias ligadas ao ato sexual, das quais a criança tem conhecimento filogenético, está nela relacionada a atos sádicos que são levados a cabo pelos criminosos e conclui então, que há uma analogia entre as fantasias de crianças pequenas com crimes horrendos.

O criminoso sente-se perseguido e vai destruindo o outro não só na fantasia como também na realidade. O mundo passa a ser formado por inimigos, seu ódio se vê justificado e há um alívio do seu sentimento de culpa. 
O amor não está ausente, mas está escondido e enterrado, pois, se o objeto odiado e perseguido é também amado, há uma situação intolerável que só se resolve com a supressão das recordações e dos sentimentos de amor e, então, o criminoso passa a odiar e perseguir seu objeto amado.

Segundo Sá (1987), o ato delinqüente não é necessariamente a expressão de um desajuste psicológico ou perturbação mental, mas, um comprometimento da eficácia de adaptação da conduta.

Esse comprometimento é resultado do interjogo de fatores internos e externos, que começam a atuar desde as primitivas relações da criança com o ambiente e cujo efeito é cumulativo e gradual.

O autor justifica esta hipótese através das teorias de Freud e Melanie Klein. Lembra que o ego desenvolve seus limites a partir das primeiras relações com o objeto.

Graças às frustrações, desenvolve-se o princípio de realidade que juntamente com a capacidade de sublimar as pulsões, determinarão a eficácia de adaptação do indivíduo.

Em todo indivíduo existe um potencial agressivo, decorrente do instinto de morte. Parte dele é dirigido contra objetos externos em favor do organismo e outra parte, é incorporada pelo superego e dirigido contra o ego.

Assim, o superego, que nasce da introjeção das figuras parentais, vai ter suas características determinadas por estas figuras reais somadas à intensidade dos impulsos destrutivos .

O superego condiciona o desenvolvimento do sentimento de culpa, quanto mais severo o primeiro, mais intenso será o segundo, características estas que podem levar o indivíduo a um ciclo de práticas de atos destrutivos e auto punição, possuindo sua raiz nos sentimentos destrutivos recalcados voltados, na verdade, às figuras parentais. Tal ciclo caracterizaria o comportamento delinqüente. 
Sá (1987) afirma que as teorias de Freud e Klein não subestimam a influência de fatores ambientais, que será tanto mais forte, quanto mais precocemente acontecer.

Cita, como exemplo de interferências ambientais, pais severos, não amorosos, punitivos, brigas em família, vivências de violência, separação da família ou estado de carência material, pois estas situações podem ser sentidas como castigos.

Na obra de Winnicott, a tendência anti-social é um dos temas básicos. Suas idéias trazem importantes contribuições à compreensão do tema e são exploradas, posteriormente, por outros autores.

Com uma compreensão metapsicólogica singular, ele recorre ao fracasso ambiental para explicar características específicas, que levariam ao surgimento da tendência antisocial (Winnicott, 1999).

A singularidade de seu pensamento se faz notar na concepção de que a agressividade é intrínseca à natureza humana, algo inato, porém, igualada a motilidade, ao movimento corporal e ao estabelecimento do eu e não - eu e ao começo da relação com o mundo externo.

A agressividade da criança surge na relação com o mundo desde a mais tenra idade, na relação com a mãe, como uma voracidade que leva ao uso implacável do objeto.

Assim, a agressão é uma reação direta ou indireta à frustração e ao mesmo tempo, uma das fontes de energia do indivíduo.

Nos estágios iniciais do desenvolvimento emocional, porém, há conflitos e desintegração potenciais e a relação com a realidade externa não está firmemente estabelecida, a personalidade ainda não está bem integrada e o amor primitivo ainda tem um propósito destrutivo, pois a criança pequena ainda não aprendeu a enfrentar seus instintos. 
Quando vai se estabelecendo a noção de eu e não - eu, a criança se dá conta de que o objeto que ela ataca vorazmente em momentos de excitação, é o mesmo que ela deseja em momentos mais tranqüilos.

Esta percepção leva a um sentimento de culpa que só é aliviado pela contribuição que o bebê pode dar a sua mãe e essa oportunidade só surge através da sua presença confiável.

A agressividade, então, é coexistente com o amor, pois a elaboração do impulso destrutivo se converte no desejo de reparar, de construir e de assumir responsabilidade.

Toda a agressão que não é negada e pela qual se aceita a responsabilidade pessoal dá forças ao trabalho de reparação e restituição. Havendo a capacidade de reconhecer a própria crueldade, é possível sublimá-la.

O desenvolvimento da capacidade de envolver-se depende, então, de um ambiente suficientemente bom e exige uma complexa organização do ego que existirá através de cuidados adequados com o bebê e a criança e torna-se uma questão de saúde.

A não estabilidade da presença da mãe, leva à perda da capacidade de envolvimento e ao surgimento de angústias e defesas como a clivagem e a desintegração assim como, o não desenvolvimento de um ambiente interno bom.

O ódio ou a frustração ambiental desperta reações de acordo com o montante de tensão já existente em sua fantasia inconsciente.

A criança pode se tornar agressiva por auto defesa contra ataques imaginários, e a agressividade existente dentro dela passa a inibir o impulso criativo.

A destrutividade passa a ser excessiva ou incontrolável, passa a ser negada ou dramatizada, então as forças cruéis ameaçam dominar as forças do amor e o indivíduo pode provocar seu controle por uma autoridade externa. 
Na tendência anti-social há uma falha, omissão ou privação da vida familiar ocorrendo em um momento da evolução da vida psíquica, momento no qual o ego já alcançou certo grau de maturidade e em que está ocorrendo a fusão entre as raízes libidinais e agressivas da personalidade.

Nesse momento, ainda não houve tempo hábil para a incorporação de um sentimento de segurança ambiental e criação de um ambiente interno bom, porém já há a capacidade de perceber esta falha ambiental.

A sua percepção leva a criança a buscar uma estabilidade que suporte a tensão resultante de seu comportamento impulsivo.

Quando ela comete um ato anti-social, está buscando a mãe e a autoridade paterna, para que ela possa recuperar seus instintos primitivos de amor, sentimento de culpa e desejo de reparação.

Através de suas pulsões inconscientes, busca o objeto, algo perdido em algum lugar e, não encontrando, busca em outro.

Se em nenhum momento desta busca for oferecida a estabilidade ambiental, os atos anti-sociais se repetirão, até que o indivíduo se torne um criminoso, cada vez mais deprimido, despersonalizado e incapaz de sentir a realidade

Assim, quando não é possível encontrar as figuras materna e paterna, ela busca o controle na comunidade e na sociedade, compelindo o meio a retroceder com ela ao ponto em que houve a falha ambiental, a fim de repará-la.

Por essa razão, Winnicott (1999) considera a tendência anti-social como um sinal de esperança, um pedido de socorro.

Winnicott vê duas direções para a tendência anti-social: uma para o Roubo, onde há uma busca pelo objeto perdido, expressando a privação do objeto primeiro, outra direção é 
da destrutividade, onde há uma busca pelos limites que é a expressão de uma privação do oferecimento de controle.

No primeiro caso, estaríamos tratando da privação propriamente dita relacionada à figura materna e, no segundo caso, seria a deprivação relacionada à figura paterna.

Os delinqüentes procuram o controle externo para não se sentirem ameaçados pela loucura, possuem motivos inconscientes e devem, sob sua proposta, serem tratados como pessoas doentes que não conseguiram desenvolver um sentimento de segurança. Eles só podem se sentir livres quando estão sob controle, na liberdade sofrem ameaça de loucura.

O autor condena a tomada de uma atitude sentimentalista, pois por trás desta existe ódio recalcado, ainda que seja perigoso adotar - se um objetivo puramente terapêutico nas decisões judiciais, que seu tratamento adequado não seja a psicanálise e sim o provimento de cuidados com a criança onde ela possa experimentar e testar seus impulsos, com o apoio ambiental.

Para Winnicott (1999) o meio desempenha um papel fundamental. Outros autores, de algum modo, parecem concordar com esta premissa.

Sá (2001) esclarece que estas privações emocionais são conseqüência de relações insuficientes, distorcidas, descontínuas ou distorcidas entre o bebê e as figuras parentais

Zimermann (1999) explicita que a violência manifesta na adolescência nada mais é do que uma resultante da desestruturação do psiquismo que data desde o desenvolvimento emocional primitivo. Como decorrência das falhas de maternagem, os abandonos prematuros, são excessos de estímulos que o ego não pode ainda suportar.

Para Jurandir Costa, (1984), um fato da cultura que só existe em relação a uma lei e sua causalidade está relacionado a um elemento genérico: a infração, e a individual: o tipo de infração. O autor explica que a violência não está ligada apenas a uma questão de busca por gratificação imediata ou provocações 
masoquistas produto de culpa inconsciente. Estes sujeitos considerados anti-sociais exigem da realidade o que lhes foi extorquido pelo ambiente materno. Assim, a delinqüência torna-se uma trincheira contra a perda do sentido de realidade.

A retomada dessas teorias nos faz perceber que os estudos que se fizeram no sentido de buscar a gênese da alma criminosa, utilizando a metapsicologia psicanalítica, tiveram embates em razão da relação com a realidade e as instâncias psíquicas, com a questão da busca por um ponto de fixação na escala evolutiva psicossexual, da formação e estrutura do superego ou na tentativa de estabelecer a relação instinto de morte e ambiente ou da agressão inata e frustração.

\section{4 - A adolescência}

As questões da juventude parecem ter sempre interessado ao homem e encontramos

referências sobre os fenômenos específicos desse período nas obras de pensadores, como: Platão, Aristóteles, Sócrates, Shakespeare e Rosseau.

Dias (2001), realiza um estudo retrospectivo em relação ao histórico do entendimento sobre o adolescente e afirma que ocorreram importantes alterações.

Contudo, as concepções que remontam ao Egito antigo, Grécia, Idade Média, Renascimento e Era Moderna guardam semelhanças com as atuais no que tange ao destaque deste período.

Aristóteles já apresenta uma descrição de características que ele acredita serem típicas da juventude que se assemelham àquelas encontradas na Idade Média, pois, possuem um caráter valorativo e visão julgadora. 
No mundo ocidental, ainda segundo a autora acima citada, paulatinamente, há uma alteração da representação social e, por volta do século XVIII, iniciam - se as recomendações educativas em relação à adolescência.

Ela ressalta que, em todos os períodos históricos, há uma inconformidade com o desvio da norma e uma não aceitação deste período, afirmando que houve uma estigmatização deste.

A partir da segunda metade do século XIX e século XX, estas questões passam a receber um maior trato científico. Na psicologia, encontramos estudos a partir do começo do século (Campos, 1990).

Hoje se torna assunto em voga, não apenas em razão do desenvolvimento científico a respeito e do reconhecimento de sua importância na história do indivíduo, mas também - e principalmente - em razão de questões de ordem social, econômica e política que influenciam e são influenciadas pelas questões da juventude.

Dias (2001) ainda afirma que a Era Moderna tornou a adolescência o centro das atenções, criando uma cultura adolescente, com um caráter e interesse mercadológico.

Assim, várias linhas de pensamento e diversos posicionamentos científicos tentaram lançar luz ao fenômeno. É unânime, porém, a assunção da multicausalidade do fenômeno adolescente.

É necessário que façamos uma distinção entre dois termos comumente confundidos, mas que, apesar de intrincados, são específicos: Puberdade e Adolescência.

O termo puberdade se refere a modificações biológicas que ocorrem a partir de uma determinada faixa etária, sendo a época em que estas transformações ocorrem, variada de indivíduo para indivíduo, pois são motivadas por fatores como: clima de região de residência, doenças, condições de nutrição e aparato genético. 
Trata-se de um fenômeno universal onde o corpo inicia sua preparação para a procriação, acontecendo devido à maturação das células do hipotálamo que enviam sinais para que a glândula pituitária libere hormônios estimulando as glândulas endócrinas, determinando importantes alterações corporais, tais como:

- surgimento de caracteres sexuais secundários, aumento de peso, altura e proporções corporais, fenômenos como menstruação, ejaculação e crescimento de pêlos.

A puberdade, portanto, é um marco importante na escala maturacional e ciclo vital do indivíduo; porém, falar em adolescência vai além, pois, esta engloba aspectos biológicos, psicológicos, sociais e culturais, adquirindo, assim, características peculiares em razão destes fatores ( Becker, 1991; Campos, 1990).

Segundo Levisky (1998) é uma revolução biopsicossocial, pois, é a culminação de um processo que se iniciou no nascimento, caracterizando-se pela estruturação final da personalidade e aquisição da imagem corporal, levando a mudanças definitivas no modo como a pessoa se relaciona com o os pais, com o mundo e com ela mesma.

Para Winnicott (1999 e 2000) é essencialmente um período de descoberta, uma experiência existencial que leva ao estabelecimento de uma identidade.

Knobel e Aberastury (1981. p.26) afirmam ser uma:

Etapa da vida durante a qual o indivíduo procura estabelecer sua identidade adulta, apoiando-se nas primeiras relações objeto parentais internalizadas e verificando a realidade que o meio social Ihe oferece mediante o uso de elementos biofísicos em desenvolvimento à sua disposição e que só é possível quando se consegue o luto pela identidade infantil. 
As aquisições que ocorrem nesse período se dão nos mais diversos níveis e concomitantemente. A diferenciação é de âmbito didático.

As mudanças cognitivas, por exemplo, são de importância cabal e caracterizam o novo modo como o adolescente passa a lidar com o mundo.

Elas o capacitam a entender as questões do mundo adulto e o reconhecimento da realidade externa, possibilitando uma visão critica sobre a família, a sociedade e sua condição social.

Para Piaget (1979) este período representa a transição de operações concretas para operações formais. Desenvolvendo-se, assim, a capacidade para operações de ordem superior, passando-se a usar estratégias sofisticadas, empregando seletivamente as informações, elaborando hipóteses ou proposições teóricas, desenvolvendo o raciocínio abstrato, capacidade de análise, crítica e generalizações.

O adolescente tem, portanto, tarefas a serem cumpridas na ascensão rumo à identidade adulta.

Osório (1989) afirma que estas atividades são: reafirmação da imagem corporal, substituição dos vínculos simbióticos por relações objetais de autonomia plena, elaboração de lutos referentes à perda da condição infantil, estabelecimento de valores próprios e assunção de papéis sexuais.

Knobel e Aberastury (1981) referiram-se ao que eles denominaram Síndrome Normal da Adolescência, conjunto de características dessa fase da vida, definição ainda atual , que encontra convergências com estudos de outros autores e é assim , caracterizada:

1 Busca de si mesmo e da identidade: 
A identidade é a consciência que o indivíduo tem de si mesmo, de sua condição como uma unidade pessoal e distinta sendo intrinsecamente ligada à imagem corporal e identidade sexual.

As mudanças do corpo e das expectativas do mundo externo podem ser sentidas como uma invasão, há um conflito interno entre a tentativa de reter as conquistas infantis e alcançar um novo status, surgindo a angústia e a despersonificação, como defesas utilizadas para lidar com as mudanças que estão acontecendo em seu corpo.

Winnicott $(1999,2000)$ afirma que o adolescente está empenhado em descobrir seu próprio eu para que lhe possa ser fiel, eles lutam por sentirem-se verdadeiros e só podem fazer isto na medida em que não aceitem soluções falsas, mesmo que sob a condição de desconsiderar muito da sua história passada.

\section{Tendência Grupal:}

Os pais deixam de ser figuras de identificação e há uma busca por novos modelos. Há a necessidade de intercâmbio e aceitação levando à busca de similares e à formação de grupos.

Para Winnicott (1989), porém, o adolescente é um ser isolado e a constituição de grupos caracteriza-se mais como uma medida defensiva aos ataques externos.

3 Necessidade de intelectualizar e fantasiar;

4 A intelectualização é utilizada como defesa contra as ansiedades causadas pelos conflitos desse processo, ocorrendo um cerceamento da ação que leva a um refúgio da fantasia.

\section{Crises Religiosas;}

A busca por segurança faz com que se apegue a valores e ideologias que lhe forneçam condutas rígidas a seguir.

\section{Deslocalização temporal;}

Ocorre em decorrência da irrupção de partes não elaboradas da personalidade e de um estado mental caótico, característico desta fase.

7 Evolução Sexual;

Acontece a evolução de uma sexualidade auto-erótica para a sexualidade genital adulta. Há a reedição do conflito edipiano, com a diferença de que a possibilidade real de atuação dos desejos incestuosos torna-o mais angustiante. 
A masturbação e a fantasia contribuem na elaboração desse processo, agindo como forma de aliviar a tensão causada pela urgência fisiológica, afastando, muitas vezes, a possibilidade de acontecimento real do intercurso sexual, pois o adolescente não tem condições de viver uma relação de real intimidade, já que não vive relações objetais plenas e, sim, na grande maioria, relações de caráter narcísico.

8 Atitude social reinvidicatória:

Em decorrência da intelectualização, busca-se alterar o mundo externo na tentativa de dar ordem ao mundo interno, que se apresenta de forma caótica. Winnicott (1989) afirma como estando entre as necessidades do adolescente a de desafiar e de enfrentar a sociedade.

Levando-se em consideração a necessidade destes de serem autênticos, eles podem rejeitar, tudo que é anterior a seu tempo, bem como, os adultos que de alguma forma se identificaram com a sociedade atual.

9 Contradição nas manifestações de conduta;

A pouca estabilidade da identidade e a diversidade de identificações não possibilitam uma linha rígida de conduta e estabelecem-se contradições sucessivas.

10 Separação progressiva dos pais;

Ocorre um processo de agressão e desvalorização dos pais no sentido de se diferenciar, afirmar-se e estabelecer uma identidade pessoal, oscilando entre o desejo de autonomia e a necessidade de proteção. No mundo interno, os pais são mantidos separados e onipotentemente controlados em razão da reedição do conflito edipiano.

11 Flutuações do estado de humor e ânimo:

Dominado por sentimentos de ansiedade e depressão que são determinados por mecanismos de introjeção e projeção no processo de elaboração de lutos, passa por micro crises maníaco-depressivas que, levam a alterações do estado de humor.

A adolescência, portanto, apresenta padrões psíquicos peculiares devido às tarefas concernentes a esta fase.

Neste período há um desequilíbrio das forças do Id, Ego e Superego e só gradualmente, o ego vai estabelecendo uma síntese do passado, presente e futuro.

Há um incremento das defesas obsessivas e do recalque, o Ego pode sofrer uma regressão defensiva diante da intensa angústia e da emergência das pulsões, ocorre uma perturbação das relações entre Ego e o Superego, um afastamento dos objetos libidinosos amorosos e incremento da erotização. 
Assim, os adolescentes agem por descarga sem usar adequadamente sua criatividade, pois, o desenvolvimento cognitivo fica debilitado quando os mecanismos de defesa falham.

O adolescente revive as situações do passado e as dificuldades das experiências infantis e é de fundamental importância que haja um equilíbrio entre as necessidades instintivas e do meio ambiente.

Trata-se, portanto, de uma crise necessária para o desenvolvimento do indivíduo onde as ansiedades, conflitos e incertezas se magnificam.

A estabilidade não ocorre sem se passar por um certo grau de conduta patológica e um certo período de depressão; sendo assim, muito do que se mostra no adolescente, está presente em pessoas doentes.

A estreita relação entre as características do adolescente normal, da pessoa com tendência anti-social e com quadros psicopáticos são afirmadas por diversos autores, como: Aberastury e Knobel (1981), Osório (1989), Levisky (2000,2001) e Winnicott $(1999,2000)$.

Nos adolescentes normais, contudo, a patologia seria transitória e o modo como o adolescente será capaz de superar estes conflitos e elaborá-los depende, principalmente, de sua história prévia.

O padrão de enfrentamento baseia-se, nas condições estabelecidas nos primeiros anos de vida e os conflitos serão tão mais intensos quanto maiores os pontos de fixação.

Entrando em jogo a biografia do indivíduo, características dos primeiros vínculos afetivos, além da organização estrutural, dinâmica e econômica do aparelho mental. (Winnicott, 2000; Levisky, 1998)

Só há uma cura para os ‘males’ do adolescente, segundo a concepção de Winnicott, que é o transcorrer do tempo. 
As características biopsicossociais do adolescente levam-no a uma sintomatologia que se faz notar, principalmente, na área comportamental e devido a sua fragilidade egóica e à situação de caos psíquico, há a predominância de mecanismos psíquicos primitivos.

A pressão das pulsões dos instintos e exigências do meio diminuem sua capacidade de sublimar, reprimir e postergar. Assim, eles tendem a passar ao ato com maior freqüência, com descargas de impulsos agressivos e sexuais.

Ele protesta contra o mundo, na impossibilidade de compreendê-lo ou integrar-se nele. Além disso, os vários lutos que devem ser elaborados durante esse período levam os adolescentes a viverem uma constante depressão.

Na tentativa de iludir os sentimentos de dor e perda, ele se utiliza de mecanismos de defesa que o levam a desvalorização dos objetos.

Partindo dessas proposições, Aberastury e Knobel (1981), Osório (1989), Levisky $(2000,2001)$ e Winnicott $(1999,2000)$ comparam o comportamento adolescente com condutas psicopáticas ou de tendência anti-social, pois, no psicopata também encontramos uma desvalorização do objeto com a negação do afeto, dos sentimentos de dor ou perda, da culpa e da depressão.

A incapacidade de tolerar frustrações e o fracasso na simbolização são as expressões do fracasso no uso de defesas adequadas.

Pelo DSM-IV, porém, o diagnóstico de psicopatia só é fornecido após os 18 anos e até lá seria caracterizado um transtorno de conduta .

Dias (2001), critica uma visão estigmatizante e patologizante da adolescência e acredita, que esta é resultante de uma determinação sócio cultural, pois, em povos primitivos, encontramos a preservação da transicionalidade do jovem e um 'treino' na inserção do mundo adulto, tendo a adolescência nessas culturas características distintas. 
Podemos concluir, então, que o psicodiagnóstico realizado com adolescentes deve, indiscutivelmente, levar em consideração as peculiaridades desta fase.

Tomando-se o cuidado em discriminar o que lhe é próprio e o que representa um quadro psíquico com maior comprometimento.

Fica-nos claro que este é o momento da revivescência e magnificação de conflitos anteriores.

\section{5 - Adolescência e Delinqüência}

São crescentes os números de jovens infratores inseridos cada vez mais precocemente no crime. Há, também, um aumento dos crimes de natureza mais grave cometido pelos adolescentes, com diminuição dos casos de furto e aumento dos casos de roubo e lesão corporal, estatísticas estas referentes ao período de 1993 a 1996. (Adorno, 1999).

Os menores de 18 anos são inimputáveis, isto é, não lhes é atribuída responsabilidade por atos delituosos considerando que, estes não teriam condições de compreender o caráter criminoso de seu ato, assim, quando trata-se de menores , não se fala em crime e , sim, em Ato Infracional.

Segundo o Estatuto da Criança e do Adolescente (ECA), o ato infracional é uma conduta comparável a um crime ou contravenção penal. Como é elucidado, crime é toda a ação ou omissão com intenção de fazer mal que é contrária à lei e legalmente punida, possuindo a Contravenção Penal as mesmas características, porém, com menor gravidade. (Mello, 1997).

A autora afirma que este posicionamento não tem contribuído para a redução da prática criminosa e questiona o quanto o jovem realmente não tem condições de compreender esses atos. 
Na literatura há uma distinção entre infrator como aquele que transgrediu uma lei e delinqüente como aquele que possui uma situação de vida estigmatizante vivendo à margem da criminalidade. (Brandão, 2000).

Ele ressalta a importância de fatores relacionados ao meio, que servem como potencializadores ou redutores dos riscos proveniente de questões individuais ou familiares.

As pesquisas que definem a delinqüência passam por questões psicológicas ou sócio legais. Na Psicologia, em geral, fala-se de diversos padrões de comportamento anti-sociais praticados que têm a tendência de aparecer no início da vida e se intensificar com o transcorrer do tempo (Conte, 1996).

Conte (1996) esclarece como fatores precipitadores da delinqüência juvenil: a interação entre pais e filhos com ênfase na rejeição, comportamentos aversivos em relação à criança, brigas na família e a repetição geracional destes padrões. Ainda cita as relações da criança com a escola, com o grupo de pares desviantes, aspectos pessoais, tais como: baixa auto-estima, perda de valores e apego, alienação, sentimentos de desamparo, isolamento, impotência, falta de perspectivas, minimização de emoções, além de questões ambientais e sociais.

Afirma ainda que eventos estressores externos atuam mais profundamente sobre aqueles indivíduos que já possuem padrões comportamentais negativos ou recursos pessoais ineficientes e que a delinqüência é resultado da ocorrência combinada de uma série de fatores.

Feijó (2001) esclarece os fatores de risco para a infração como sendo primeiramente associados a altos níveis de estresse biopsicossocial e certo grau de vulnerabilidade individual. A autora lembra que os modelos explicativos da delinqüência juvenil incluem-se em três níveis de abrangências sendo: estrutural, individual e sócio psicológico. 
O nível estrutural, segundo ela, abrange as condições de âmbito social e/ou econômico, o nível individual considera os mecanismos internos do indivíduo como fatores precipitantes, tais como:

- características de personalidade, níveis de inteligência, padrões desenvolvimentais, distúrbios de comportamento, manifestação de conflitos subjacentes, distinções neurofisiológicas e hereditárias, traços de personalidade, como: impulsividade, inabilidade nas inter-relações, ausência de culpa e insensibilidade à dor e às transgressões.

O nível sócio psicológico, por sua vez, abrange questões como a quebra de vínculos com instituições como o Estado, a igreja, a escola e a família, sendo estes vínculos a base para o controle do adolescente.

Grunspum (2002) traz a questão da introdução do termo 'resiliente', para descrever indivíduos que possuem algumas condições satisfatórias em seu desenvolvimento que lhe dão a capacidade de lidar com as adversidades da vida de forma positiva.

No sentido de enriquecer a compreensão sobre o perfil do adolescente Infrator recolhemos dados com a Promotoria de Justiça de Infância e Juventude da Capital, constantes em seu banco de dados a respeito dos adolescentes atendidos no período de julho de 1998 a junho de 2001, que são mais bem visualizadas nas tabelas e gráficos em anexo.

Assim, constatamos que no período analisado, os adolescentes atendidos no Ministério Público são em sua grande maioria do sexo masculino - média de 90.19\% no período e quantitativamente de maioria branca - média de $59.41 \%$ no período.

Contudo, se compararmos com o contingente da população total de negros e brancos, são apreendidos mais negros. Com idade de 17 anos- média de 37.75\%. Provenientes do Estado de São Paulo - média de 88.34\% no período, residindo em 
habitação do tipo própria - média de 76.49\% . Provenientes de famílias com renda entre 0 e 3 salários mínimos - média de 44.32 \% no período.

Estudando no momento da apreensão - média de 54.77\% no período, com escolaridade entre $5^{\circ}$ a $8^{\circ}$ série do ensino fundamental - média de $59.88 \%$ no período. Sem trabalho média de $65.45 \%$ no período.

Sendo que 32.19\% deles não estudam nem trabalham. Não são usuários de drogas média de 71.28\% no período. É a primeira apreensão destes - média de 79.63 no período.

Em relação às infrações cometidas, verificamos que em sua maioria trata-se de Roubo, seguido por Furto e depois Porte ou Tráfico de Drogas, conforme tabela.

Brandão (2000) realizou pesquisa traçando o perfil sócio-demográfico dos infratores e características dos atos infracionais no município de São Paulo, através da estatística e geoprocessamento do banco de dados do Ministério Público. Constatou que em relação ao contingente de São Paulo, há um maior número de infratores negros, maioria natural de São Paulo, do sexo masculino, originários de famílias com renda abaixo da média, há um expressivo abandono escolar e sabendo - se que não há correlação entre o local de residência e a exclusão social.

No trabalho de Assis e Souza com 30 adolescentes infratores do Rio de Janeiro, também encontramos dados importantes. Na população por elas estudada, metade dos entrevistados tinha até a $4^{\circ}$ série do primeiro grau, sendo que mais de $70 \%$ já haviam abandonado os estudos, pelos seguintes motivos: necessidade de trabalhar, desentendimento no ambiente escolar e pouca supervisão familiar. A idade média era de 16 anos. Só 21\% viviam em lares em que conviviam com pai e mãe. Era freqüente a ausência da mãe nos cuidados iniciais, distanciamento da figura paterna, agressões na família, histórico familiar de envolvimento infracional e mortes violentas. Apenas 14\% deles não possuíam nenhum caso de envolvimento infracional na família. A maioria morava em comunidades de baixo poder aquisitivo, onde aconteciam situações de violência, possuíam 
o grupo de amigos também fazendo parte do crime, maioria era usuário de drogas, 90\% deles já havia executado algum trabalho, 20\% iniciou a vida laboral na faixa dos sete anos.

As autoras levantam que os infratores demonstraram fortes necessidades de consumo. Possuem, em grande parte, planos futuros relacionados ao trabalho. Em geral, possuem uma visão positiva de si mesmos. Mas, também se vêem com características agressivas e impulsivas. (Assis; Souza, 1999).

Pesquisa realizada com 31 adolescentes infratores e 31 irmãos ou primos destes não infratores, das cidades do Rio de Janeiro e Recife, todos do sexo masculino, aponta que a maioria dos jovens infratores procede de lares desorganizados. Sendo que $46 \%$ dos pais e 13 \% das mães tinham falecido ou abandonado o lar, 46 \% moravam só com a mãe. As famílias com mais de 3 filhos somavam 61\% . Em 19\% dos casos os pais tinham constituído novo lar e em 29 \% dos casos as mães. Os não infratores distinguiam-se pela maior convivência com os genitores. Apenas 26 \% dos casos tiveram os primeiros cuidados em tempo integral, é comum a falta de cuidado durante suas vidas, não recebendo os cuidados adequadas em relação à higiene, alimentação ou ao acompanhamento escolar e, ainda assim, há uma idealização da figura materna que sempre é vista de forma positiva. São provenientes de famílias de baixa renda, com os genitores inseridos em trabalho não especializado e com pouca escolaridade, e relatos de diversas privações durante a infância. Nessas famílias, são comuns os agravos de saúde física e mental, alcoolismo, violência, suicídio e envolvimento infracional.

Entre os primos infratores os casos de envolvimento infracional ou violência na família são menores, as relações familiares estão repletas de desentendimentos e desafetos e, mesmo assim, há um certo conformismo com esta situação. 
O infratores atribuem a fatores, externos a sua entrada no crime e acreditam que o sucesso de uma pessoa é determinado por uma habilidade inata e não de um compromisso pessoal; porém, admitem a sua responsabilidade pelo ato infracional.

O sentimento de valorização da vida é algo pouco cultivado entre eles e a ociosidade é comum. Há um código moral específico da criminalidade, a maioria possui consciência de existir o certo e errado, porém, sentem-se compelidos de forma incontrolável a um caminho incorreto.

Eles escolhem caminhos mais fáceis, possuem menos prudência e capacidade em medir as conseqüências, menos controle de suas ações e paciência, menos capacidade de refletir sobre suas vidas e fazer planos futuros. (Feijó, 2001).

Foi realizada uma pesquisa de cunho exploratório - descritivo com 17 adolescentes autores de atos infracionais inseridos em um programa de Liberdade Assistida desenvolvido pelo juizado da Infância e Juventude de Belém - Pará que utiliza o formulário como instrumento de coleta de dados procura verificar as condições psicossociais destes adolescentes. (Duarte, 1995).

Constantino (2001) utilizando como método qualitativo as entrevistas e como método quantitativo as escalas psicométricas, busca entender como a vivência familiar pode influenciar o jovem em direção ao ato infracional.

A amostra estudada tem as seguintes características: é em sua grande maioria do sexo masculino, 94.12\% da região urbana 82.34\%, na faixa etária entre 16 e 17 anos. Encontram - se no primeiro grau de escolarização 82.35\%, em sua maioria residem em casa de madeira com em média três cômodos e cerca de cinco a sete habitantes. Vivem com a mãe e possuem algum tipo de conflito com algum membro da família. Mais da metade possui pais separados, $58.83 \%$ ou eram órfãos, $11,76 \%$, sendo que $29.41 \%$ possuem pais casados. 
Grande maioria não possui atividades remuneradas, possui amigos, 94.12\% e atividade sexual na mesma proporção. Maioria é usuário de drogas, 64.71\%, possui os jogos e brincadeiras de rua como lazer e a televisão como acesso à cultura. O Furto é, de modo geral, a infração mais cometida. A partir desses dados, a autora realiza as seguintes reflexões: a família destes passa por alterações em sua dinâmica, com relações conflituosas ou ausências. Essa situação associa - se a uma condição social, econômica e cultural marginal, com poucas possibilidades de crescimento, desligamento do âmbito escolar que leva a uma dificuldade de inserção no mercado de trabalho. Ainda assim, também demonstram que apresentam expectativas para o futuro, como condição social, de trabalho e processual.

Pesquisa com adolescentes infratoras da cidade do Rio de Janeiro afirma que a vulnerabilidade destas jovens fica explícita nas situações de exclusão social, negligência, abandono da família, da escola, da comunidade e sociedade em geral, dificuldade de estabelecimento de limites e vivências de violência de todos os níveis As autoras afirmam a importância de se perceber como cada uma dessas jovens vivenciaram essas situações de forma única. Concluem que as instituições socializadoras na formação da criança são fundamentais, o fracasso da família e da escola e, ainda, que há uma forte necessidade de consumo que é suprida pela inserção no tráfico de drogas que se apresenta como um mercado de trabalho atraente. (Assis e Constantino, 2001).

Foi realizada uma análise compreensiva dos discursos de quatorze adolescentes infratores atendidos no Centro Educacional Monsenhor Messias, em Sete Lagoas - MG. (Madureira, 1996). Neste estudo ela pede que se responda a pergunta: O que é ser adolescente infrator? 
Os adolescentes inclusos na pesquisa tinham entre 12 a 18 anos, eram do sexo masculino, e estavam inseridos nos regimes de privação de liberdade, semi-aberto e aberto.

A autora verifica que os discursos são permeados por ambivalência, ambigüidade e sofrimento. Deixam transparecer uma posição de impessoalidade frente à vida, carência de todos os tipos de recursos, falta de segurança, de afeto e de auto-estima.

O ser adolescente infrator é definido como quem pratica o ato infracional, dos quais se tem a noção de serem ilícitos. Há o conhecimento sobre as regras, mas uma impossibilidade de opção, como se a esta situação não houvesse escolha. A culpa permeia grande parte dos discursos, associada ao ato em si ou as relações familiares. Existe um conformismo, no qual ele não se reconhece como sujeito ou agente. Ainda assim, surge a perspectiva de um futuro diferente e é só neste momento em que ele abandona a impessoalidade.

Um estudo com adolescentes infratores e seus irmãos não infratores, realizado na cidade do Rio de Janeiro e Recife, objetivando conhecer os motivos que levam jovens a trilhar caminhos distintos e visando à prevenção da delinqüência juvenil, identificando os fatores com predisposição à infração (Assis; Souza, 1999).

Utilizando entrevistas semi-estruturadas e uma abordagem quantitativa dos dados, as autoras adotam um modelo conceitual explicativo da delinqüência juvenil que incorpora três níveis:

- nível estrutural, isto é, as condições sociais; o nível sócio-psicológico, isto é, incorpora o controle social da família, escola, instituições e a auto - estima; o nível individual que incorpora aspectos biológicos e psicológicos.

Para as autoras desse trabalho, a delinqüência juvenil mostra-se não como fruto de uma patologia individual, mas sim de estruturas e conjunturas sócio - culturais. 
Demonstram que os principais fatores de risco associados aos infratores são: consumo de drogas, círculo de amigos, tipos de lazer, auto - estima, posição entre irmãos, princípios éticos, presença de vínculo afetivo em relação à escola, sofrer violência dos pais. A família representa, muitas vezes, para o jovem uma influência negativa. Os mecanismos sociais de miséria, narcotráfico, a lógica da cultura do consumismo, influência perversa da comunidade e banalização da violência são outros fatores de risco.

Pesquisa realizada sobre as Representações Sociais de Justiça em Adolescentes Infratores utilizou entrevistas com 20 jovens com idade entre 12 e 17 anos, atendidos na FEBEM da cidade de Presidente Prudente - SP. (Menim, 2000).

Foi percebido que estes possuíam uma visão predominantemente repressiva sobre justiça, com diferentes concepções acerca do tema, pouca reflexão e até mesmo uma dificuldade em conceituar abstratamente.

Mazzaro (2001) faz uma investigação clínica da personalidade de adolescentes homicidas através da utilização do Desenho-Estória, e com uma interpretação Kleiniana, chega às seguintes conclusões: imagens paternas negativas, pelo fato dos genitores serem ausentes, violentos ou não amorosos. Incapacidade da figura materna de satisfazer anseios afetivos, em grande parte primitivos, como a satisfação de necessidades lúdicas e orais. Relação mãe - filho quantitativa ou qualitativamente empobrecidas, figuras maternas introjetadas com características negativas. Temor pela destruição dos objetos internos e externos, objetos internos dotados de destrutividade e caráter persecutório, pouca ação reparadora. Estado interno de conflito entre as forças do bem e do mal, isto é, entre as tendências reparadoras e desagregadoras, recursos egóicos débeis, presença de superego implacável (Mazzaro, 2001). 
Sá (1987) realizou pesquisa com sentenciados cumprindo pena na detenção de São Paulo entre janeiro de 1980 e fevereiro de 1981 que voltaram ao convívio social, em um total de 50 casos, buscando entender a questão da reincidência criminal. Entre outras conclusões, afirma que a relação entre a reincidência na maioridade e a prática de delitos na menoridade é contraditória, pois é menor com os que não praticaram delitos na menoridade, mas aumenta quando a questão é sobre passagem em instituição para menores e ele justifica esta relação contraditória questionando a veracidade das informações transmitidas pelos detentos.

Pignot (1993) utiliza-se de uma abordagem clínica e escuta terapêutica para tentar compreender dois casos de práticas de furtos na adolescência. A população utilizada nessa pesquisa é diferenciada, pois, além de encontrarem-se em um contexto clínico, fazem parte de uma classe e perfil e a autora chega a conclusões positivas em relação a responsividade dos adolescentes ao trabalho psicoterapêutico.

Celener (1999) realiza uma pesquisa de caráter clínico , realizando avaliação Psicodiagnóstica e social com 32 adolescentes infratores internados e 32 adolescentes não infratores inseridos no ensino público, todos do sexo masculino, relacionando a questão do Desamparo nos dois grupos. A autora utiliza o Questionário Desiderativo, o T.A.T. ( Teste de Apercepção Temática) e o MISS (Mannheim Interview on Social Suport) , sendo este último um inventário que avalia a rede de relações sociais. Através dessas técnicas, ela pôde perceber que os adolescentes infratores outorgam menor relevância à relação com familiares , há uma menor presença de vínculos de cuidados , bem como a capacidade de oferecê-los, eles possuem uma rede de relações menor e não apresentam satisfação com relação a estas , evidenciando que , muitas vezes, negam a importância do que carecem, pois surge maior necessidade de dependência, neste grupo, nas técnicas projetivas. Desta forma , conclui que há uma correlação entre as vivências objetivas de desamparo e as conseqüências psíquicas desta , que se evidencia na comparação entre os grupos.

Em pesquisa de caráter qualitativo, Constantino (2001) utilizou entrevistas com 12 adolescentes cumprindo medidas de internação e semiliberdade na cidade do Rio de Janeiro, buscando revelar a percepção do risco que elas possuíam. Ela afirma que o jovem 
infrator é vítima e ré, pois a delinqüência é conseqüência de uma socialização e autoimagem assinalada pela marginalização, exclusão e estigma.

Um estudo sobre jovens infratores e seus irmãos não infratores de Assis (1999) demonstrou que a realidade e as várias situações de violência eram vivenciadas de modos muito distintos e, assim, como a forma de lidar com estes. Para esta autora, as conseqüências de vivências deste nível variam de acordo com diversos fatores, como o tipo de violência que se sofre, o tempo de submissão a esta, o acúmulo de situações de risco, atributos pessoais, suporte ambiental. Assim, não é possível estabelecer uma relação causal direta e linear. A autora ressalta, contudo, que a delinqüência juvenil é um processo de escolha, pois, apesar das restrições das opções de escolha, nem todos que vivem nas mesmas características desenvolvem os mesmos comportamentos.

Conte (1996) baseou-se em uma abordagem cognitivista com 47 crianças e adolescentes com idade entre 8 e 16 anos, de ambos os sexos, de uma comunidade pobre. Eles passavam por uma avaliação inicial e eram separados em subgrupos terapêuticos, com o objetivo de desenvolverem habilidades pró-sociais e de autoconhecimento, com o objetivo de prevenção. A autora constata que os participantes dos grupos terapêuticos tiveram ganhos significativos.

A autora afirma que a relação entre pobreza e agressão não é direta, pois, tem a ver com a falta de recursos, vulnerabilidade orgânica, dificuldades de aprendizagem e adaptação escolar, convivência com situações de violência, exclusão social na comunidade e outras situações relacionadas.

As pesquisas citadas apontam para um multicausalidade da delinqüência juvenil, que incluem questões relativas ao ambiente social, cultural, político e familiar, bem como, as relacionadas à subjetividade que caracterizaria certa vulnerabilidade do jovem. 
Na compreensão globalizada do problema, é preciso considerar fatores individuais e, por outro lado, em uma compreensão individualizada, é necessário considerar fatores gerais.

Os problemas sociais, econômicos e políticos abrangendo as desestruturações familiares, a violência de toda a espécie, desenham um cenário pouco acolhedor para o desenvolvimento psíquico de nossas crianças e jovens.

A nação não tem sido uma 'mãe suficientemente boa ' e seus filhos privados das necessidades psicoafetivas e sociais mais básicas protestam.

Não sofre apenas o coletivo, mas cada ser envolvido como vítima ou agente da criminalidade e violência.

Vale nos questionarmos se a sociedade atual oferece esta possibilidade com tantas complexidades que coloca à inclusão do adolescente no mundo adulto.

Para as classes sociais mais baixas impõem-se dificuldades no âmbito da própria sobrevivência em um país onde 10\% dos mais ricos absorvem 47\% da renda monetária ( Levisky, 2001).

Dados do Instituto Brasileiro de Geografia e Estatística (IBGE) revelam que hoje a população de crianças, adolescentes e jovens estaria em torno de 80 milhões, o que corresponde a $50 \%$ do total dos habitantes, mais de sete milhões estão inseridos no mercado de trabalho, mas metade deles sem remuneração fixa.

A cada década, eleva-se significativamente o número de mortes por causas violentas entre os adolescentes. Os jovens hoje, em todo o cenário mundial, são vítimas e agentes das mais diferentes guerras, expostos a todo tipo de violência. São usados pela mídia tornandose escravos do consumismo, gerando inúmeras frustrações àqueles que não podem adquirir os bens oferecidos pelo mercado (Gotlieb, 2002). 
As frustrações tornam-se demasiadamente intensas, há um incremento da angústia e a debilidade do ego e os mecanismos prévios de solução de conflitos não possibilitam a plena realização da adolescência

As mais diversas questões levam as crianças a conviverem e inserirem-se na criminalidade desde muito cedo, muitas vezes, sendo usadas e, posteriormente, tornando-se agentes atuantes no crime. Esta inserção acaba sendo apoiada por famílias miseráveis e justificada pelo status que a sociedade urbana ocidental oferece à violência. ( Gall, 2001; Spitscovisky, 2001)

Vivemos em um sistema de psicotização da sociedade e a nação, que deveria exercer um papel continente às necessidades de seus filhos, os deixa em situação de miséria em diversos sentidos e lhes nega o acesso a seus direitos mais básicos.

As elites utilizam a seu favor as características da globalização e da democracia e, ao invés de possibilitar a todos o acesso a essas conquistas, as desigualdades sociais se acentuam na mesma velocidade das transformações tecnológicas.

Os jovens são expostos ao que podem ter sem ter possibilidades de realmente usufruir de qualquer benefício ou facilidade destes processos.

A sociedade está cada vez mais injusta e cruel, predominam as relações humanas de má qualidade, deturpando os modelos identificatórios.

Comportamentos violentos tornam -se meios de auto afirmação e trazem o status de poder, na sociedade, na mídia e nas próprias famílias que se tornam incapazes de lidar com seus próprios conflitos de outra forma e consequentemente geram filhos desajustados.

A violência em todos os níveis cresce em escalada e as grandes vítimas acabam se tornando as crianças e os adolescentes que privados de oportunidades, com futuro pouco 
promissor e carentes psicoafetivamente e socialmente, passam a ter nos atos anti-sociais as únicas alternativas para sair do anonimato ou até mesmo para sobreviver.

Enquanto as pessoas se virem obrigadas a permanecer em um estado semi - humano, haverá agressão e violência. Ela se torna a única via com a qual contam para liberar uma tensão insuportável e alcançar a sensação de significação

Santos (2002. p.190):

A experiência da violência generalizou-se de tal forma, principalmente, nas comunidades carentes que se desenvolveu, entre os jovens, um sentimento de que as condutas de risco são uma modalidade eficaz de resposta ao risco. (Constantino, 2001).

A violência de qualquer nível vivenciada por crianças provoca modificações em seu potencial relacional e ontológico e elas correm sério risco de apresentar psicopatologias de algum tipo no decorrer de suas vidas e um desenvlvimento moral truncado (Grunspum, 2002; Assis 2002).

Os jovens são vulneráveis e susceptíveis às influências do meio, assim, os valores culturais e ideológicos preconizados em nossa sociedade que são transmitidos através das relações familiares incidem diretamente em seus comportamentos (Levisky, 2000).

O adolescente responde à violência com uma entrada prematura na vida adulta e na interrupção da formação da identidade que levam a comportamentos autodestrutivos, como: uso de drogas, delinqüência, promiscuidade e agressividade.

Vale refletir e justificar como este ambiente social está influenciando a formação de distúrbios desta ordem. 
Através das suas inúmeras características injustas e cruéis, a sociedade está impossibilitando as famílias de gerir seus conflitos e oferecer modelos identificatórios adequados aos nossos jovens.

Se o ambiente é fundamental para a formação de uma psique sadia, então pode se questionar que tipo de estrutura psíquica está sendo possibilitada em meio ao caos social e familiar em que se desenvolvem nossos jovens e crianças.

Vale questionar a posição de se pensar em um diagnóstico da delinqüência juvenil que se utilize, apenas, do prisma da personalidade psicopática em detrimento de uma tentativa de compreensão da questão da violência (Guagliardi, 1990).

Acrescentamos, ainda, que esta compreensão deve estar baseada, também, em todos os fatores relacionados ao ambiente social, cultural e político atual.

\section{6 - Atendimento ao adolescente infrator no Brasil}

A história do atendimento ao menor infrator no Brasil se confunde com a história do atendimento às crianças abandonadas, carenciadas e socialmente excluídas. (Violante, 1985; Brandão, 2000; Marcilio, 2001).

Os primeiros registros neste sentido datam já da colonização, quando os jesuítas chegaram ao Brasil, voltaram sua atenção para as crianças indígenas e órfãos que eram fruto de relacionamento entre índios e brancos. No sentido de incutir-lhes a sua cultura e utilizá-los como sua mão de obra. Estas crianças eram afastadas do convívio sócio familiar e recolhidas em “Casas”.

Quando chegavam à adolescência, porém, eram obrigadas a abandonar essas casas e grande parte delas passava a perambular pelas ruas e viver na miséria. 
No período colonial, então, surgiram as primeiras Casas de Misericórdia no sentido de dar apoio, principalmente médico, às crianças abandonadas, além das colônias agrícolas e orfanatos. Estas casas de caráter religioso subsistiam de donativos e espalharam - se pelo país.

Surgem neste período as Casas da Roda, onde as crianças abandonadas eram colocadas em um dispositivo giratório que preservava a identidade dos que a abandonavam, o que desta forma acabou por estimular o abandono das que cresceram.

Nestas instituições, as crianças viviam em péssimas condições e havia alto índice de mortalidade. Aquelas que sobreviviam eram encaminhadas precocemente ao trabalho, abandonadas ou dependiam da "caridade cristã".

Com o Brasil independente, o aumento do aglomerado urbano e a péssima qualidade de vida da população levou ao aumento da criminalidade, o corpo policial acabou por levar grande número de pessoas, inclusive crianças e jovens, para as "Casas de Correção".

Em 1861 é decretada a criação do Instituto de Menores e a Casa de Correção da Corte, para dar abrigo às crianças e aos jovens em situação de criminalidade, porém, elas irão surgir apenas no final do Século XIX.

Nestas casas, o maior objetivo era a educação moral e religiosa e o instrumento utilizado para tanto eram os castigos corporais, o período de internação era longo: ia desde oito anos até a idade de maioridade.

Ao término desta internação, os jovens eram transferidos para escolas de guerra. Em 1891 a maioridade penal é estabelecida aos nove anos.

Com o Brasil República, a situação social e econômica e a abolição da escravatura aumentaram o número de pessoas, vivendo em condições precárias e, consequentemente, o aumento do número de infrações cometidas por crianças e adolescentes. 
Neste período, médicos, juristas e outros homens da ciência começaram a propagar idéias higienistas que preconizavam a pobreza e a hereditariedade como fatores determinantes do comportamento delitivo, assim, seria necessário o afastamento das crianças de seu ambiente sócio familiar a fim de que recebesse educação e hábitos adequados.

Lutavam, também, pela criação de um juízo específico para menores que é criado em 1923 e em 1927 entra em vigor o código de menores.

Este código estabelece a maioridade penal em 18 anos e transforma o 'menor' em uma categoria jurídica

Em 1941, no governo Getúlio Vargas, é criado o SAM - Serviço de Assistência ao Menor, na tentativa de congregar o aparato público e instituições particulares, criando normas para seu funcionamento e atendimento, tendo caráter centralizador no Ministério da Justiça.

Estes órgão, porém, continuaram a atender precariamente as crianças e houve um inchaço nas instituições, ocorrendo grande número de fugas, rebeliões e denúncias de abusos e maus tratos, até que uma comissão de inquérito extingue o SAM.

Em 1964 com o golpe Militar é criada a FUNABEM - Fundação Nacional de Bem Estar do Menor -, que passa a tratar o menor como assunto de Segurança Nacional, herdando do SAM as locações, funcionários, internos e as práticas repressivas, sendo financeira e administrativamente subordinada à Presidência da República.

A FUNABEM não concretizou a sua propostas originais de prevenção e descentralização até que em 1990 se extingue com a criação da FEBEM-(Fundação Estadual para o Bem Estar do Menor). 
Em 1990 é promulgado o Estatuto da Criança e do Adolescente (ECA), que se trata de uma doutrina de proteção integral à criança, respeitando sua condição de pessoa em desenvolvimento, acolhendo os quatro princípios adotados na Convenção dos Direitos Humanos, inspirado na Declaração de Genebra (1924), Declaração Universal dos Direitos Humanos das Nações Unidas (1948), Convenção americana dos Direitos Humanos (1969).

Assegura a não discriminação, superior interesse da criança, direito à vida e ao desenvolvimento, respeito à opinião, diferencia as crianças que estão em risco pessoal e social daqueles que estão em conflito com a lei.

Após o ECA, os termos 'menor' e 'delinqüência' perderam a propriedade, por serem carregados de um caráter depreciativo. (Feijó, 2001).

Assim, fala-se hoje de criança ou adolescente que cometeram ato infracional ou usase o termo jovem em conflito com a lei.

Pontua-se uma série de direitos a eles, como: saber quem o está apreendendo, ser informado de seus direitos, ter a família avisada, ter conhecimento total e formal do ato infracional, ter todas as condições de defesa, ser ouvido pessoalmente pela autoridade judicial, solicitar a presença dos pais e ter sigilo quanto ao fato. (Mello, 1997).

Os jovens que cometeram atos infracionais na faixa entre 12 e 18 anos serão julgados por juízo especial, aplicadas medidas sócio educativas que visam à ressocialização do adolescente, corrigindo-lhe a conduta infracional, sendo que a privação de liberdade e afastamento do núcleo familiar deve acontecer, apenas, em último caso.

Todas as medidas, segundo a autora supracitada, devem levar em consideração a capacidade do adolescente para cumpri-las, bem como as circunstâncias e gravidade da infração, só podendo ser aplicadas se houver indícios suficientes da autoria e ocorrência do fato. 
O ECA, então, estabelece seis tipos de medidas sócio educativas que podem ser aplicadas ao jovem em conflito com a lei. Elas são assim caracterizadas, segundo os artigos 112 a $121:$

- Advertência:

“(...) admoestação verbal, que será reduzida a termo e assinada” ·

- Obrigação de Reparar o Dano:

Trata-se de restituição, ressarcimento ou compensação do prejuízo da vítima, quando se tratar de danos a patrimônio.

- Prestação de Serviços à Comunidade:

Realização de tarefas gratuitas de interesse geral.

- Liberdade Assistida:

Medida que visa a acompanhar, auxiliar e orientar o adolescente, estando ele em liberdade.

- Semiliberdade:

Forma de transição ao meio aberto, onde apesar de estar inserido em unidade específica da FEBEM, o adolescente tem a possibilidade de realizar atividades externas.

- Internação:

Trata-se de medida privativa de liberdade, sujeita aos princípios de brevidade, excepcionalidade e respeito à condição de pessoa em desenvolvimento.

As medidas de Semiliberdade e Internação têm o período estabelecido em no mínimo seis meses e no máximo três anos, com o limite de idade até os 21 anos.

Sendo que o juiz estabelece a periodicidade em que devem ser realizados relatórios pelos técnicos da unidade, relatando sobre o desenvolvimento do adolescente no cumprimento da medida. 
A Instituição FEBEM atende a grande parte da tramitação processual do adolescente em conflito com a lei, bem como ao atendimento das medidas sócio educativas, sendo responsável pelo atendimento das medidas de Liberdade Assistida (LA), Semiliberdade e Internação.

Sua estrutura é constituída por uma Unidade de Atendimento Inicial (UAI), por onde todos os adolescentes passam, a fim de se realizar uma primeira triagem antes de serem atendidos pela Promotoria do Ministério Público, situado no Fórum Especial das Varas da Infância e Juventude.

Se o promotor decidir pela internação provisória do adolescente, até que seu processo seja avaliado por um dos juizes das varas especiais, ele retornará à UAI e lá será distribuído para uma Unidade de Internação Provisória, (UIP).

Cada unidade destas é caracterizada por um perfil de adolescente que pode receber, pois, segundo o ECA, qualquer tipo de internação deve respeitar características do adolescente, como: sexo, idade, compleição física e grau infracional.

Nestas unidades o adolescente aguardará, sobre tutela do Estado, a sua audiência com o juiz onde será determinada a medida sócio educativa que se aplicará a seu caso.

Nesta decisão o juiz deve levar em consideração a gravidade da infração cometida, como também a situação psicológica, social e familiar do adolescente.

Se lhe for concedida remissão, arquivamento do processo ou aplicadas medidas de advertência ou Prestação de Serviços à comunidade, é encerrado seu processo atual com a FEBEM, se lhe for aplicada medida de Liberdade Assistida (LA), ele será encaminhado para um posto de L.A., onde será acompanhado por técnicos da FEBEM ou de organizações conveniadas do estado. 
Na medida de Semiliberdade, ele será transferido para uma Unidade Específica, o mesmo ocorrendo no caso de internação.

A internação possui, na verdade, um tríplice aspecto: punir, intimidar e recuperar o infrator, contudo, esses três aspectos não se coadunam e um impede a realização do outro. (Jessé, 1998).

O autor afirma que os sistemas fechados não dão possibilidades de êxito aos profissionais responsáveis pelo tratamento, já os agentes não podem conciliar uma tarefa custodial com uma missão terapêutica. Segundo ele, as medidas em meio aberto vêm sendo amplamente utilizadas no mundo inteiro. Enquanto no Brasil elas representam 2\%, na Alemanha chegam a 85 \%. Nos países com esta estrutura, a reincidência é de em média 25\%, enquanto no Brasil chega a $85 \%$.

Alves (2001), em pesquisa realizada buscando investigar as alterações na psicodinâmica de adolescentes privados de liberdade, realiza o diagnóstico psicológico de tipo compreensivo no início da internação e após seis meses desta.

A autora afirma que os dados do estudo sugerem que ocorre um empobrecimento do diálogo e trocas afetivas, distanciamento entre pais e filhos, uma acentuação da presença de mecanismos de defesa mais regredidos na relação com o meio, com um predomínio da pulsão de morte. Assim, conclui que a internação teria originado conseqüências desfavoráveis à adaptação social e um agravamento no estado emocional dos adolescentes (Alves, 2001).

Encontramos outros estudos realizados na FEBEM-SP, como a de Miraglia (2001) que realiza estudos onde buscou reconstruir o percurso dos jovens internados, ressaltando as relações sociais, as representações sociais e a construção simbólica desta. Guirado (1985), por sua vez, busca pensar as questões da relação sujeito-instituição, analisando as 
representações nos discursos de internos e profissionais. Procura mostrar espaços e momentos distintos onde são construídas representações sociais acerca dos jovens infratores, reflete sobre o espaço simbólico da constituição da FEBEM, das audiências ocorridas nas Varas Especiais Infantil e da Juventude (VEIJS), e na descrição da FEBEM Tatuapé

Brito(2002) através de entrevistas não diretivas colhe material para produzir um conjunto de histórias de vida com os funcionários da FEBEM-SP, no sentido de elucidar a vivência destes com a história da Fundação .

No Brasil ocorreram muitos avanços, nos últimos anos, em relação ao atendimento ao adolescente que pratica atos infracionais.

A lei, hoje, assegura, um tratamento adequado a sua condição de pessoa em desenvolvimento, com a possibilidade de lhe ser proporcionado recursos adequados a esta condição.

Na prática, porém, sabemos que há muito caminho a se trilhar, principalmente, se levarmos em consideração a efetividade das ações a este respeito e as condições de vida e perspectivas de nossa população jovem. 


\section{2 - JUSTIFICATIVAS E OBJETIVOS}

A partir das pesquisas recentes e literatura consultada, relacionadas à delinqüência juvenil, percebemos dados alarmantes acerca do tema.

Há um expressivo aumento da ocorrência de delitos cometidos por crianças e jovens, sendo que estes acontecem cada vez mais em tenra idade e com caráter mais violento.

Os jovens e adolescentes passam a ser vítimas e agentes da violência e do crime e este fenômeno toma tal amplitude que passa a ser de interesse geral, em nível social, político e científico.

Percebemos, contudo, que o ritmo de pesquisas realizadas, principalmente em âmbito nacional, não acompanha o crescimento da relevância e da necessidade de compreensão e enfrentamento do problema.

Há um consenso quanto à necessidade de se buscar novos métodos de abordagem desta questão, a fim de se estabelecer estratégias eficazes de intervenção.

Estas, contudo, só podem ser alcançadas através de um esforço conjunto, marcado pela realização de pesquisas em várias disciplinas e correntes teóricas, já que se trata de uma questão que possui sua origem marcada pela multicausalidade. 
A psicologia tem buscado contribuir com o tema da delinqüência, da criminalidade e da adolescência desde os seus primórdios com seus autores clássicos.

O levantamento bibliográfico realizado, em termos de pesquisas contextualizadas à nossa realidade mais recente, revelou que as mesmas buscam, em geral, traçar perfis ou baseiam - se em teorias acerca de representações sociais ou vertentes sociais.

Há certa escassez no que tange a contribuições da psicologia clínica e do psicodiagnóstico, utilizando - se a metodologia que lhe são peculiares.

A preocupação com essa contribuição pode ser justificável, pois, a Psicologia clínica pode contribuir com o resgate acerca da compreensão sobre a subjetividade de cada ser envolvido que não pode ser desconsiderada, incorrendo-se no risco de reduzir o adolescente à infração ou tratá-lo de forma moralizante ou estigmatizante que em nada contribui com uma solução adequada.

O psicodiagnóstico pode oferecer uma série de dados para a compreensão ampla, profunda, permitindo a visualização de possibilidades e o estabelecimento de estratégias interventoras e preventivas, tanto em nível individual quanto coletivo.

Devemos considerar, contudo, que sua realização com esta população requer uma série de cuidados. Primeiramente, porque crianças e adolescentes são seres em desenvolvimento e as características específicas da etapa de desenvolvimento em que se encontram estão relacionadas com aspectos culturais, sociais, psicológicos e biológicos e estes devem ser considerados.

No caso de adolescentes, como foi visto, pode se tornar difícil a determinação do que é próprio desta fase e, portanto, transitório, e o que é característico de um quadro mais mórbido, pois, acredita-se no meio científico que neste período o adolescente está sujeito a uma série de desequilíbrios, principalmente em nível comportamental. 
Outra questão a ser examinada é que um psicodiagnóstico realizado com adolescentes infratores pode trazer dados que levam a conseqüências jurídicas e de ordem prática, como o auxílio na determinação de medida sócio-educativa mais adequada a cada caso.

Assim, não basta fornecer um diagnóstico de Transtorno de Conduta com conseqüências estigmatizantes. Sendo necessária uma compreensão profunda e globalizada para subsidiar a intervenção que leve em consideração as necessidade específicas.

O psicodiagnóstico compreensivo, por exemplo, tem se demonstrado um recurso útil em várias situações e contextos, inclusive, na utilização com crianças e adolescentes.

Este trabalho pretende trazer uma compreensão sobre o tema que nos propusemos a estudar. Tem como objetivo geral verificar a utilidade do Psicodiagnóstico Clínico de natureza compreensiva no estudo de aspectos do funcionamento psíquico e da personalidade de adolescentes infratores, bem como a relevância dessa compreensão no estabelecimento de medidas preventivas e interventivas de natureza individual ou coletiva , embasando , assim, um trabalho tanto psicoterapêutico como psicossocial. 


\section{3 - MÉTODO}

Nesta unidade procuramos discutir os aspectos metodológicos da pesquisa . Descrevemos as características do Método Qualitativo e do Estudo de Caso. Podemos notar que este se configura como o mais adequado em trabalhos com enfoque clínico.

Descrevemos, ainda, os parâmetros utilizados para a escolha dos sujeitos, das técnicas e dos instrumentos empregados.

\subsection{O Método Qualitativo - A Utilização do Estudo de Caso}

Toda pesquisa pressupõe uma postura que torna possível a investigação a partir de uma determinada perspectiva. Esta pesquisa possui um caráter qualitativo, o qual segundo Martins e Bicudo (1975) busca a compreensão particular do fenômeno que se estuda, isto é, não do objeto em si, mas da maneira humana de vivenciá-lo.

Para Triviños (1995), a pesquisa de caráter qualitativo tem como base a flexibilidade na ação investigativa, pois ela se caracteriza pela ausência de hipóteses rígidas definidas a priori permitindo formular e reformular hipóteses à medida em que se realiza a pesquisa. 
Há a escolha de um assunto ou problema, coleta e análise de informações, porém essas etapas não possuem divisões estanques e no processo de desenvolvimento da pesquisa, novos estudos podem ser necessários. Seu teor dependerá do referencial do pesquisador que tem como função principal descrever os fenômenos.

Alguns instrumentos são mais indicados a estudos desta natureza, são eles: as entrevistas, questionários abertos, a observação livre.

Esta pesquisa baseou-se no método de estudo de caso, com o emprego de entrevistas e de instrumentos projetivos.

O estudo de caso nasce de uma tradição médica e se refere a uma análise detalhada de um ou mais casos individuais, supondo-se que, a partir daí, pode-se obter conhecimento de um determinado fenômeno. Tendo como propósito o conhecimento sobre o grupo estudado, tenta desenvolver proposições teóricas acerca deste. Não priorizando as generalizações e sim as inter-relações que podem ser feitas dos fenômenos específicos que se observa. (Becker,1999)

O trabalho baseou-se no Conceito de Psicodiagnóstico Compreensivo proposto por Trinca (1984), conforme exposto anteriormente.

\section{2 - Descrição dos Sujeitos}

Foram realizados oito estudos de caso, sendo que os adolescentes que participaram da pesquisa encontravam-se em cumprimento de medida sócio- educativa de Liberdade Assistida, explicitada anteriormente, em um Posto de atendimento conveniado à FEBEM. 
Buscamos desta forma, evitar interferências de fatores como a institucionalização e a ruptura social e familiar , uma vez que os adolescentes vivem com suas famílias.

Escolhemos casos em cumprimento de medida por envolvimento em ato infracional compatível a Roubo, viabilizando, desta forma, de comparação relacionada ao ato.

Delimitamos a faixa etária abrangida entre 14 a 16 anos, porque idades superiores ou inferiores a estas poderiam trazer dados diferenciados quanto ao estágio de desenvolvimento dos sujeitos.

\section{3 - Procedimentos}

Os casos foram recolhidos através da inserção da autora como pesquisadora em uma entidade que presta atendimento a adolescentes em cumprimento de medida de Liberdade Assistida e que é conveniada à FEBEM-SP, e selecionados, pela autora, entre aqueles que se encontravam em processo psicoterapêutico com ela.

Os adolescentes que fizeram parte da pesquisa foram submetidos a entrevista clínica, onde se buscou dados relevantes de seu histórico vital, características psicodinâmicas e outras que venham a corroborar os dados obtidos através da utilização dos outros procedimentos e também o estabelecimento de um vínculo adequado entre o pesquisador e 0 adolescente.

Quando possível incluímos os responsáveis nas entrevistas.

Utilizamos o procedimento Desenho-Estória, conforme o referencial de análise de Tardivo (1985), e o Questionário Desiderativo, utilizando o referencial interpretativo de Ninjamkin e Braude (2000)

O material utilizado foi: 
- Folhas de papel para anotações e para a realização dos desenhos

- $\quad$ Lápis preto número 2

- 12 lápis coloridos nas cores: cinza, marrom, preto, vermelho, amarelo claro e escuro, verde claro e escuro, azul claro e escuro, violeta e rosa.

O material foi fornecido e custeado pela própria pesquisadora.

Todo o processo se deu em espaço oferecido pela instituição, ocorrendo em sala específica e observando-se as condições necessárias para a aplicação destes procedimentos: menor número de ruídos, acomodações adequadas, ausência de interrupções.

Utilizamos sessões de, aproximadamente, 1 hora para a entrevista com o adolescente, bem como, a aplicação do Desenho - Estória e o Questionário Desiderativo, além da entrevista com a família, totalizando uma média de cinco sessões para todo o processo.

As informações obtidas em cada caso e a comparação entre estes recebeu, ao final, um tratamento interpretativo a luz da teoria psicanalítica.

\section{4 - Aspectos Éticos}

O presente trabalho assenta suas bases nos mais rigorosos princípios éticos baseados em dois instrumentos fundamentais: As resoluções da Comissão Nacional de Ética em Pesquisa e o Código de Ética Profissional do Psicólogo.

Assim, esclareceremos alguns pontos desta através da relação com esses dois instrumentos:

No sentido de atender a todas as exigências acima descritas, buscamos nos certificar de que os procedimentos e instrumentos utilizados eram cientificamente válidos, anteriormente experimentados e validados, como foi citado em capítulo específico. 
Os sujeitos envolvidos e seus responsáveis, bem como a instituição, foram plenamente esclarecidos verbalmente e concordaram através dos Termos de Anuência, Informação e Participação (anexos 1, 2 e 3); antes da aplicação de qualquer procedimento.

Foi lhes garantido o sigilo das informações que pudessem identificá-los,além da possibilidade de desistência e de esclarecimentos em qualquer etapa do processo.

Foi , ainda, assegurado o bem estar e o benefício dos sujeitos e da instituição envolvida através da devolução das informações obtidas.

\subsection{Instrumentos Utilizados na Pesquisa}

\subsubsection{A Entrevista Clínica}

A entrevista, para Lodi (1991) é uma forma estruturada de conversação. Mas, mais que isso, é um tipo de método de investigação utilizado comumente em ciências humanas, que pode completar outros métodos ou ser por eles completada. Isso se dá porque ela é um dos principais meios de coleta de dados e suas características enriquecem a investigação, oferecendo campo para o surgimento de interrogações e hipóteses. (Triviños ,1995)

Para Bleger (1998), além de uma técnica de investigação científica, é o instrumento fundamental do método clínico no trabalho do psicólogo não excluindo outros instrumentos e, sim, precedendo e complementando-os. O critério de cientificidade da entrevista consiste na sistematização das variáveis, transformando-as em constantes, podendo, assim, fornecer um maior rigor em sua aplicação e resultados.

Ela pode ser do tipo aberta, fechada, semidirigida, individual ou grupal. Diferenciase de uma anamnese, pois não é uma compilação de dados. 
Seus objetivos são mais amplos, abrangendo um estudo profundo de todo o comportamento do entrevistado enquanto se mantém aquela relação, pois esta é uma variável de relevância cabal, a ser estudada. O entrevistador observará toda a comunicação existente, inclusive suas lacunas e distorções através de uma dissociação instrumental, isto é, ao mesmo tempo em que se relaciona, observa e instrumentaliza. Deve , ainda, refletir sobre a transferência e a contra-transferência e buscar um nível adequado da ansiedade de ambos.

Desta forma, vai formulando hipóteses que são relacionadas às teorias por ele conhecidas e utilizadas.

Para Ocampo e Arzeno (1995), os critérios utilizados para interpretação da entrevista são os mesmos dos testes: o tipo de vínculo que se estabelece, a transferência e contratransferência, a classe de vínculos que o sujeito estabelece em suas relações interpessoais, as ansiedades predominantes, as condutas defensivas, os aspectos psicológicos adaptativos ou patológicos.

\subsubsection{O Questionário Desiderativo}


Trata-se de um instrumento de caráter projetivo em que são realizadas seis solicitações ao sujeito, as três primeiras denominadas de catexias positivas, onde é pedido que se escolha o que mais gostaria de ser se não fosse uma pessoa e depois as catexias negativas, escolhendo -se o que menos gostaria de ser. Sempre nos reinos animal, vegetal e inanimado (Grassano, 1997; Nijamkim e Braude, 2000)

As instruções segundo Ocampo (1981) provocam no paciente um ataque à integridade do seu ego, seus mecanismos de defesa e possibilidades de lidar com a morte e o modo como acontece a elaboração do luto e as ansiedade mobilizadas neste processo, fantasias e defesas em relação à morte, realização mágica dos desejos, tipo de relação objetal predominante, os temores e o modo de evitá-los. Obrigando o paciente a identificar o que deseja proteger e o que rejeita, através de sucessivas identificações projetivas. Desta forma permite avaliar as áreas de conflito, aspectos sadios e patológicos da personalidade.( Ocampo e Arzeno, 1981; Grassano, 1999, Nijamkin e Braude 2000 ).

Celener (1999) utilizou o Questionário Desiderativo com adolescentes infratores e não infratores , onde se apresentou significativas diferenciações entre estes , principalmente, no que tange a capacidade de estabelecer vínculos de cuidado, que se apresenta rebaixada nos infratores.

Utilizamos neste estudo o referencial de análise proposto por Nijamkim e Braude (2000) , que estabelece os seuintes aspectos:

- Primeira Dissociação Instrumental : Possibilidade de responder as catexias discriminando entre fantasia e realidade, fazendo uso da repressão básica e simbolização.

- Segunda Dissociação Instrumental: possibilidade de discriminar os aspectos valorizados e rejeitados pelo Ego

- Identificação Projetiva: indica a possibilidade de guardar distância emocional adequada do símbolo e do que é representado. 
- Racionalização: indica o uso adequado do mecanismo de racionalização da elaboração das respostas

- Análise qualitativa dos símbolos e elaborações utilizados nas catexias : oferece indícios sobre o tipo de ansiedade e relação objetal predominante, bem como, os traços de funcionamento psíquicos predominantes.

\subsubsection{Procedimento de Desenhos - Estórias}

Walter Trinca introduziu uma técnica que associa o uso de desenhos livres e estórias, com a proposta de apresentar uma técnica de exploração livre e dinâmica de conteúdos da personalidade. (Trinca 1987,1997)

A técnica permite o estudo de características formais e estruturais da personalidade, pois tem a particularidade de facilitar a expressão de aspectos inconscientes relacionados a pontos de angústias presentes, focos conflitivos e perturbações emergentes.

Trinca $(1989,1989,1997)$ afirma que essa técnica não pode ser considerada um teste psicológico e, sim, um instrumento auxiliar na captação de emoções e conflitos básicos do paciente, por acessar conteúdos profundos da personalidade, possibilitando um psicodiagnóstico breve e completo, principalmente se associado a entrevistas e anamneses. Trata-se de uma forma de investigação clínica, formada pela associação de processos expressivos motores e aperceptivo temáticos, baseada na teoria e prática da psicanálise, técnicas projetivas e de entrevista.

Consiste, conforme vemos em Trinca (1997), em cinco unidades de produção, seguindo todas o mesmo procedimento, em que o examinando faz o primeiro desenho, a partir do qual verbaliza uma estória.

O examinador irá efetuar questões do tipo inquérito sobre esta, por meio de associações dirigidas e por fim deve ser oferecido um título à produção.

Tardivo (1997) através de estudos comparativos com outros instrumentos e de validação deste, estruturou um referencial de análise, assim representados:

1. Atitudes básicas: aceitação, oposição, insegurança, identificação positiva ou negativa. 
2. Figuras significativas: figura materna positiva ou negativa, figura paterna positiva ou negativa, figuras fraterna ou outras negativas ou positivas.

3. Sentimentos expressos: derivados do instinto de vida ou morte e derivados do conflito.

4. Tendências e desejos: necessidades de suprir faltas básicas, tendências destrutivas ou construtivas.

5. Impulsos: amorosos e construtivos

6. Ansiedades: paranóides ou depressivas

7. Mecanismos de defesa: cisão, projeção, repressão, negação/anulação, regressão a estágios primitivos, racionalização, isolamento, deslocamento, idealização, sublimação, formação reativa, negação maníaca ou onipotente.

\section{4- RESULTADOS - ESTUDOS DE CASOS}

\subsection{Paulo}

Paulo foi encaminhado pela educadora que o acompanha no cumprimento da medida sócio-educativa, por um pedido da mãe que se preocupa com o fato dele freqüentemente evadir-se do lar, chegando a ficar dias fora.

Há seis meses, foi inserido na medida de L.A. em razão de passagem pela Vara da Infância e Juventude após apreensão por roubo. Já havia sido apreendido por furtos. 
Durante o processo Psicodiagnóstico, a mãe compareceu a duas entrevistas onde foi possível colher informações sobre seu histórico e observar a interação entre mãe e filho. Percebemos que existe afeto, porém, a mãe trata o comportamento do filho com certo humor e displicência.

Ele possui 15 anos, tem características físicas infantilizadas, mas nota-se preocupação com a forma de vestir-se, pois possui certa vaidade.

Fruto do casamento dos pais que, logo após seu nascimento, separaram-se em virtude da infidelidade e comportamento agressivo de seu pai.

Sua gestação ocorreu de forma conturbada, o casal já tinha uma filha de dois anos e vivia em conflitos. Após a separação, o pai manteve contatos esporádicos que foram se tornando cada vez mais distantes. O último se deu por iniciativa de Paulo e seu pai respondeu de forma indiferente, até que este ano falou com seu pai, apenas duas vezes, ao telefone.

Ele relata esta situação de forma aparentemente indiferente e recusa-se a aprofundar-se no assunto.

Por volta de um ou dois anos após a separação, a mãe casou-se novamente e deste relacionamento teve dois filhos, a partir de então a família passou a ser composta por sua mãe, seu padrasto e suas irmãs de 17, 10 e 8 anos de idade.

O relacionamento de seu padrasto com os filhos do primeiro casamento de sua mãe não apresenta conflito. Paulo o descreve de forma positiva, destacando seu papel relevante na família, assumindo a responsabilidade na educação de todos os filhos com atitudes que visam a impor limites e regras. 
As despesas da família são encargos do padrasto que é vigilante numa oficina mecânica e insiste em inserir Paulo nesta. Sua mãe é doméstica e a família vive de forma humilde.

Em razão da necessidade do casal trabalhar, durante alguns anos de sua primeira infância Paulo ficava sob o cuidado da tia, posteriormente sua mãe descobriu que ele sofria maus tratos por parte dela.

Ele teve um desenvolvimento normal, sem qualquer comportamento discrepante, até que com 10 anos começou a evadir-se do lar. Inicialmente, dormia na casa do cachorro, depois embaixo de veículos na rua, então, foi aumentando a distância do lar até passar dias em estabelecimentos comerciais ou imóveis abandonados.

Ele diz que, quando isso acontece, passa a maior parte do tempo sozinho e não consegue explicar seu motivos, pois não vê atrativos na rua, sai sem planejar que ficará fora e não consegue voltar. Diz, apenas, que quer ser livre como passarinho. Seu padrasto e sua mãe saem em sua busca quando ele não volta para casa.

Aos 12 anos iniciou o uso de maconha, fumava diariamente até que a mãe descobriu e foi buscar ajuda no Conselho Tutelar. Ele interrompeu o uso espontaneamente em 2001.

Nessa época começou a praticar atos delitivos e os justifica pelo desejo de posse. A mãe não consegue compreender suas atitudes, pois no convívio familiar possui comportamento tranqüilo e afetuoso.

Está cursando a sexta série do ensino fundamental e não apresenta dificuldade de aprendizagem, porém tem baixa freqüência, diz preferir ficar na rua com os amigos, dançando ou "curtindo". 
A mãe busca acompanhá-lo, chegou a matricular-se na mesma sala e vasculha seus objetos pessoais. Ao falar disso, ela o faz rindo e ambos conversam descontraidamente sobre seu comportamento.

Paulo apresenta um discurso contestador, não respeitando autoridade nos ambientes que freqüenta, tem o hábito de envolver-se em conflitos com o objetivo de resolver situações que considera "injustas", como defender garotos menores que estejam sendo agredidos na rua ou na escola.

Apresenta resistência a falar de seu histórico; quando entramos neste assunto, insiste em temas do cotidiano e seu discurso torna-se superficial.

Durante os atendimentos chega a provocar reações no psicólogo com atitudes extravagantes - certa vez compareceu com um parafuso no furo da orelha e fez questão que fosse notado, em outro momento gritou o nome do psicólogo na sala de espera.

Diversas vezes chegou atrasado e exigia ser atendido, também comparecia em dias que não estavam agendados.

Na entrevista era sempre afetuoso, fazia questão de cumprimentar e despedir-se de forma calorosa.

Foi apontado diversas vezes sobre seu comportamento, contudo ele interpretava como uma não aceitação ou como um julgamento e esquivava-se ou acabava por ter um comportamento ainda mais extravagante.

Essa situação também foi apontada buscando salientar a aceitação de suas necessidades dentro do processo, enfatizando o vínculo relacional, o que permitiu a continuidade do processo. 


\section{Questionário Desiderativo}

1 + Lagartixa: come as moscas, dá susto nas mulheres, elimina as baratas.

2 + Computador: tem muita coisa legal, dá pra ir para Internet.

3 + Alface: é verde, só pra comer, porque é cor do Corinthians.

1 - Rato: é muito feio, não tem osso, é invertebrado.

2 - Pedra: muito pesada.

3 - Melancia: é gorda. 


\section{Análise do Questionário Desiderativo}

No Questionário Desiderativo de Paulo, percebemos a presença da falha na Segunda Dissociação Instrumental, que representa a possibilidade de diferenciar os aspectos valorizados que ele e deseja conservar em si , daqueles desvalorizados que ele rejeita, pois surge a eleição de um símbolo valorizado por aspectos negativos (resposta 1+) e a rejeição de um símbolo habitualmente visto como positivo (resposta 3-).

Esse aspecto , quando relacionado com a produção global do teste, indica que parece não haver uma percepção adequada dos valores convencionais, bem como pouca capacidade em discriminar aspectos bons e maus dos objetos.

É marcante, na produção de Paulo, a falha na utilização do mecanismo de racionalização, com a presença de elaborações ilógicas e absurdas, sendo que as associações estão relacionadas a experiências internas, seguindo uma lógica interna e razões subjetivas, determinadas por aspectos emocionais, indicando, assim, fragilidade no teste de realidade. ( respostas $1+3+$, 1- e 3-)

Percebemos, também, a eleição de animais não domesticados, indicando pouco contato afetivo e a humanização dos objetos ( respostas 1+ 1- e 3-).

Todas essas características indicam traços de funcionamento psíquico, predominantemente esquizóide. 


\section{Desenhos - Estórias:}

D - E 1:

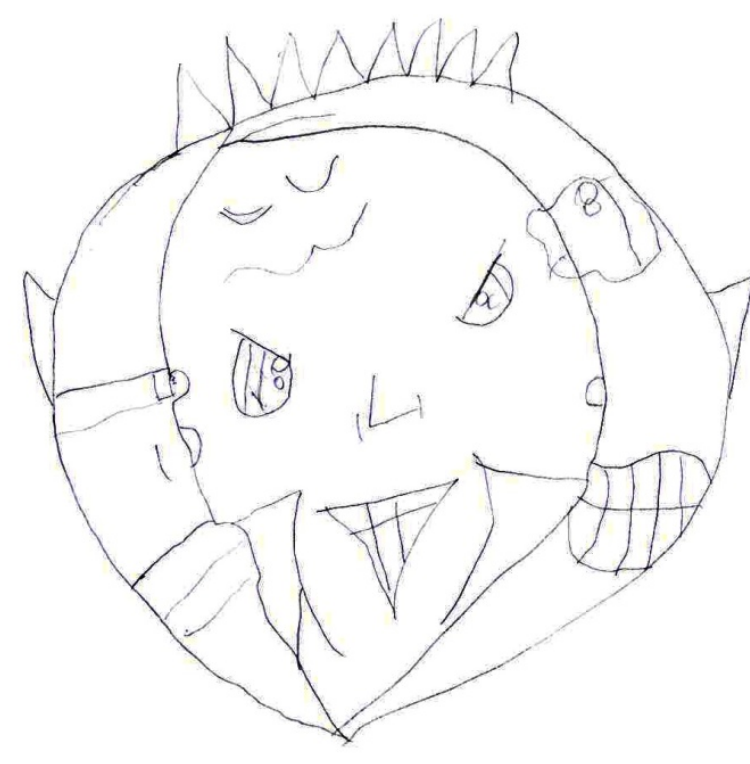

ítulo

Alien

ígena

Ele é

feio

para

dedéu, esquisito. Este sol é torto, essas luas são muito feias. Está parecendo um peixe.

Quando isso apareceu, no fundo do mar, se espantaram, os bichos, marinheiros, pediram para voltar de onde ele era e ele obedeceu e voltou e deixou uma maldição, ele falou que o mar ia secar em 3 meses, ele olha de volta e não tinha mais mar.

D- 2: 


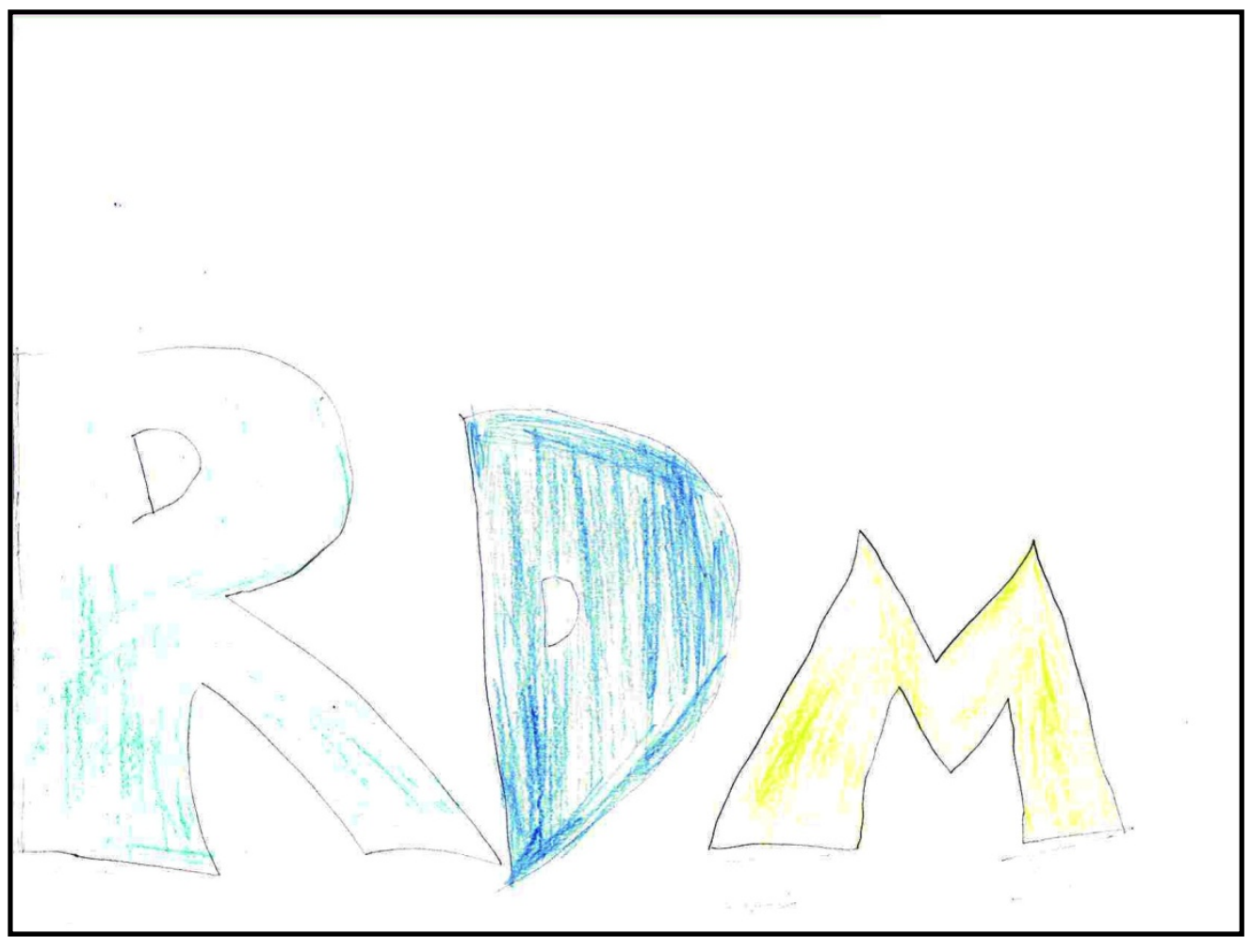

ítulo :

Rua

das

Mang

ueiras

Andan

do

pela rua, chegando na fogueira, jogo um dominó, bebe um pouquinho, dá umas voltas.

Quando chove, chove um pouco e pára, para continuar a fogueira.

Acaba a fogueira, todo mundo vai pra casa. Chega mais vinho, todo mundo começa a beber de novo e a fogueira continua.

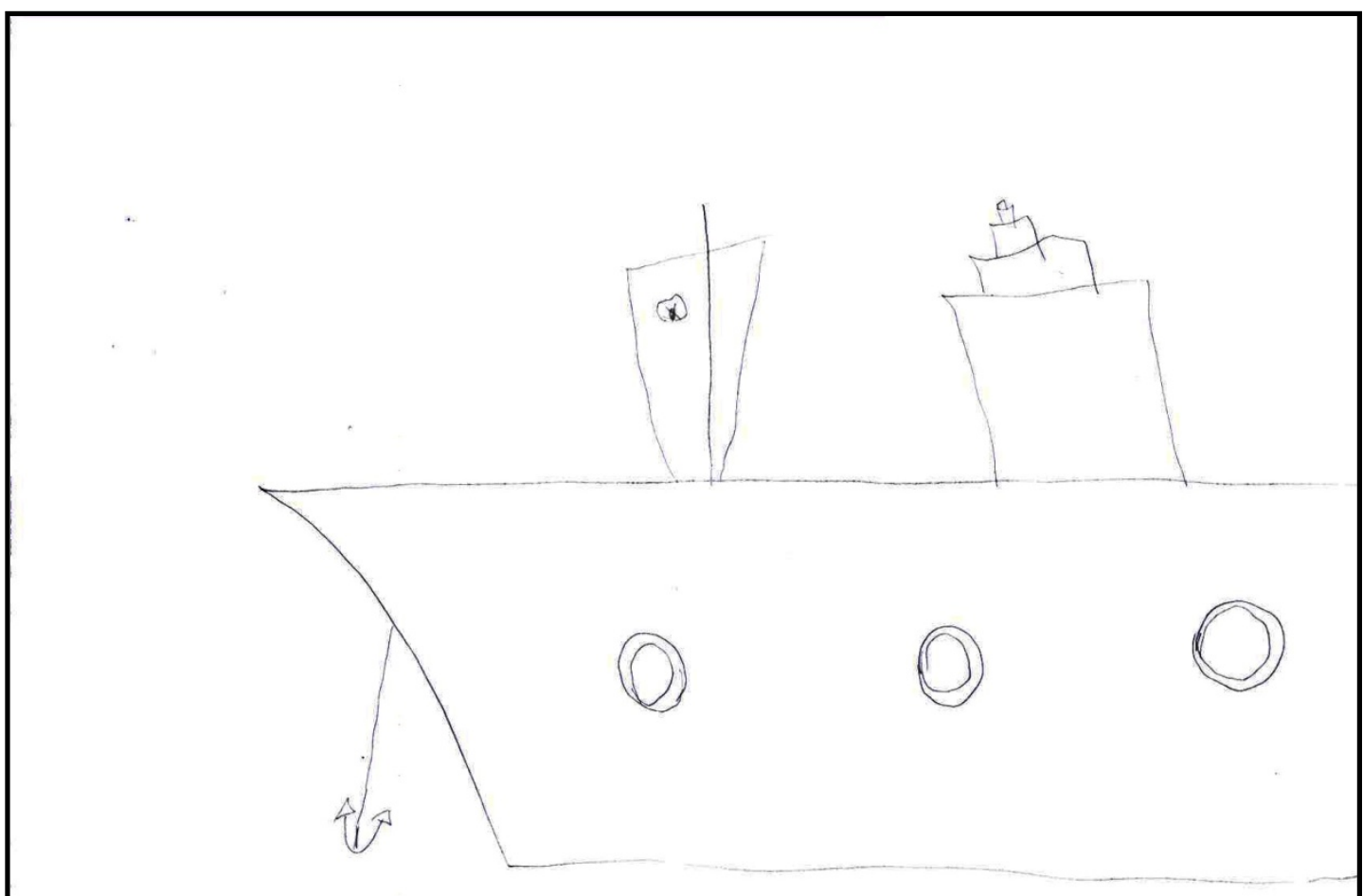

D - E 3: 


\section{Título : O Barco Mal-Assombrado}

Este barco está assombrando tudo, impossível detê-lo, quando ele aparece afunda mais de 50 barcos, todos os marinheiros tem medo desse barco.

Ele mata todos os bichos marinhos e os marinheiros também.

O capitão dele é o capitão gancho, ele é um psicopata, gosta de ver morte, ele se sente feliz em ver gente morta .

Ao ver alguém morto, ele pede para matar mais.

D - E 4 : 


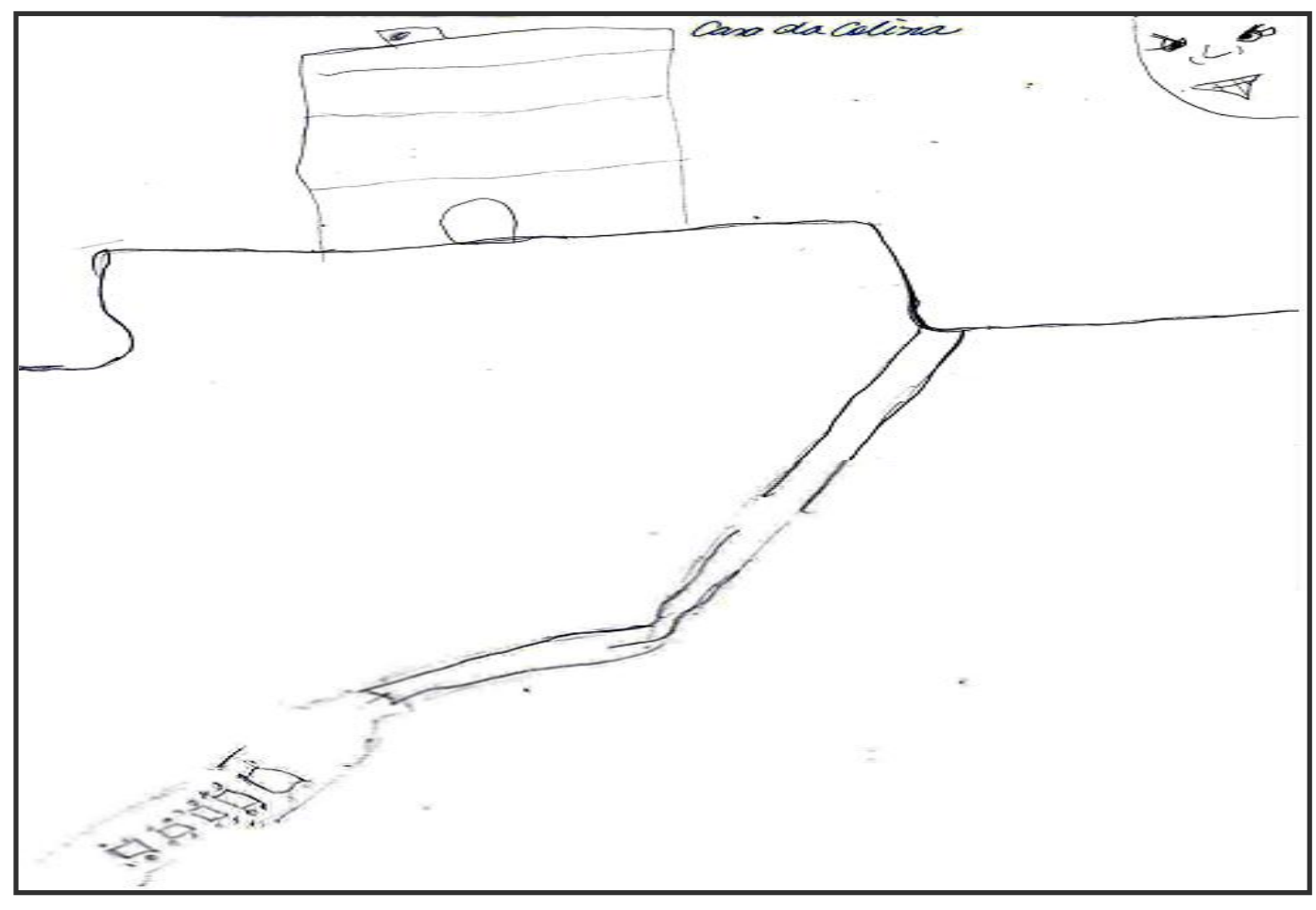

ítulo :

A

Casa

da

Colina

Há

muito

tempo atrás havia uma casa mal assombrada em cima da colina, dentro dela entrou vários médicos psicopatas, eles entravam lá para matar.

E passou uns tempos, os médicos morreram dentro da casa e o cara mais rico da cidade chamou algumas pessoas para ir na festa dos parentes que está no quadro.

Chega lá ele oferece 1 milhão de reais para quem sobreviver a noite inteira e começa a festa . 
D - E 5 :

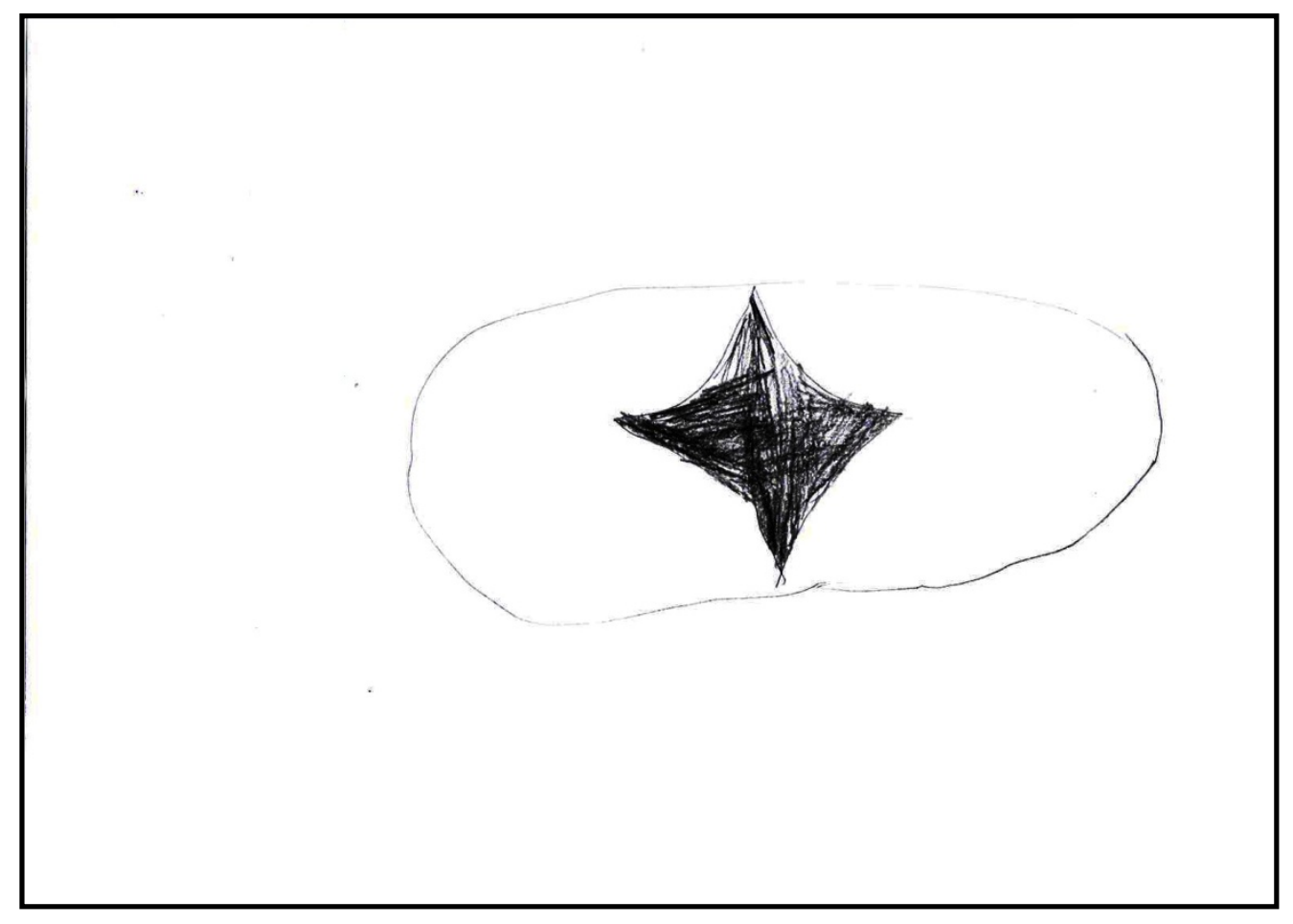

ítulo :
Nicoboc
o
Estava
na rua
caminha
ndo,
achei 50

mangos, gastei no shopping, comprei umas roupas da Nicoboco e da Mormai, comprei uma chuteira da Umbro e ainda sobrou dinheiro para ir ao cinema.

O cinema estava bom e comprei pipoca e 1 refrigerante de laranja. 


\section{Análise dos Desenhos - Estórias:}

O D - E de Paulo revela vários aspectos que caracterizam um mundo interno povoado de objetos maus, que atacam .

Neste sentido, prevalecem todas as unidades, exceto na unidade 5, atitudes básicas de oposição que se evidenciam através de respostas que denotam hostilidade e negativismo, unidade 1: " ... quando isso apareceu, no fundo do mar, se espantaram, os bichos marinhos pediram para voltar de onde ele era e ele obedeceu e voltou e deixou uma maldição, ele falou que o mar ia secar em três meses, ele olha de volta e não tinha mais mar ...". Porém, na unidade 5 parece haver uma evolução no desenvolvimento das respostas, já que ocorre a presença de atitudes básicas de identificação positiva, com sentimentos voltados para auto - imagem e busca de sua valorização, porém de modo narcísico e fundamentado no princípio de prazer.

Como figuras significativas, outras figuras no D- E são vistas como negativas, unidade 3: " ... o capitão dele é o capitão gancho, ele é um psicopata , gosta de ver morte , ele se sente feliz em ver gente morta...".

Os sentimentos expressos correspondem aos derivados do Instinto de Morte, unidade 4 : " ... há muito tempo havia uma casa mal assombrada em cima da colina, dentro dela entrou vários médicos psicopatas, eles entraram lá para matar ... ".

As tendências são destrutivas, com a presença de desejos de ataque e destruição e os impulsos também são destrutivos.

Prevalecem as ansiedades paranóides, que parecem refletir o modo como o sujeito apresenta a persecutoriedade existente em seu mundo interno., "... ele mata todos os bichos marinhos e marinheiros também ..." . 
As defesas utilizadas correspondem às mais regredidas, como a projeção de sentimentos destrutivos e de desproteção frente a um meio ameaçador.

No que se refere aos desenhos, podemos observar que são bastante regredidos, sendo que somente a segunda unidade é colorida. Existem figuras que exibem 'faces' que parecem querer provocar a reação de medo ou de impacto em quem as observa.

Percebemos que apresenta um comportamento defendido, com o uso de algumas defesas maníacas. As produções são carregadas de hostilidade, impulsos agressivos e quando há a busca por prazer, é algo primário, carecendo de sentido e de planejamento, mostrando imaturidade.

\section{Reflexão sobre o caso}

Paulo possui histórico familiar de desestruturação, seu nascimento e primeiros anos de vida foram permeados por conflitos familiares e o pai com atitudes negativas o rejeitou, além disso numa fase importante de seu desenvolvimento, sofreu maus tratos.

As constantes fugas, representadas pelas evasões do lar e o uso de drogas, parecem ser uma tentativa infrutífera de fugir deste ambiente interno perseguidor e perigoso, e também um indicativo de traços psicóticos de funcionamento psíquico.

As técnicas utilizadas confirmam a presença de uma estrutura predominantemente esquizóide, além da predominância de impulsos destrutivos e um ambiente interno perseguidor.

Os delitos são a expressão de que Paulo vive um mundo particular, com regras próprias, não aceitando a autoridade externa e impondo suas próprias leis. 
As tendências destrutivas indicam a não integração da agressividade. Os objetos que aparecem nas produções são dissociados com qualidades positivas e negativas confundidas.

Parece haver uma espera pela aceitação incondicional, espera que o mundo sobreviva a seus ataques, o que possibilita o estabelecimento de uma relação.

Grita por socorro através de atitudes bizarras para chamar atenção, busca o limite do pai percebendo que precisa dele mas não o encontra, procura sua figura em seu padrasto, sua mãe possui um comportamento com dupla mensagem, estimulando e ao mesmo tempo repelindo suas atitudes.

Em Paulo, verificamos a presença de uma confusão entre o que o Ego rejeita ou valoriza; talvez, até como reflexo das atitudes dissociadas da mãe.

A falha grave no mecanismo de racionalização e a presença de objetos internos ameaçadores , justificam as evasões do lar como uma fuga da realidade e um reflexo deste mundo interno repleto de objetos perseguidores.

Paulo precisa ser acompanhado sistematicamente, proporcionando-se um aparato ambiental que suporte sua Dissociação. 


\subsection{Tiago}

Tiago inicia o acompanhamento psicológico através de medida sócio educativa de L.A. há 06 meses, inserido após apreensão por Roubo.

Foi encaminhado ao acompanhamento psicoterapêutico a pedido da educadora, porque apresentava comportamento agitado e indisciplinar na escola.

Tem quatorze anos, possui características físicas e comportamento infantil, traja-se de forma despreocupada.

Apresenta dificuldades de relacionamento na escola com professores e com a direção, sofre constantes avisos sobre expulsão, encontra-se cursando a sétima série do ensino fundamental.

Comparece aos primeiros atendimentos acompanhado pela mãe, que participa com interesse ao realizar vários contatos com a psicóloga e com a educadora da medida.

Ela fala da vivência da família, sem conseguir ater-se a Tiago, faz sempre comparações com os outros filhos, mostra-se afetuosa, mas possui uma postura excessivamente tranqüila diante das situações, sempre demonstrando um ar de cansaço.

A família de Tiago é formada por sua mãe e outros seis irmãos, duas mulheres de 20 e 18 anos e quatro homens de 17, 16, 15 e 10 anos de idade, dois de seus irmãos estão cumprindo medida sócio-educativa também por prática de roubo.

Há 10 anos, um de seus irmãos, na época com 14 anos, foi assassinado por seu envolvimento com o tráfico de entorpecentes.

Quando inicia o acompanhamento, seus pais estavam separados há seis meses devido ao comportamento etilista do pai, que chegava a agredir a esposa e filhos, Tiago 
conta com muito pesar que o pai teve de ser contido e que chegavam a revidar suas agressões.

Mesmo nessas condições, Tiago se ressente da separação dos pais, diz que gostaria de "colar os dois juntos", chegou a pedir que a mãe voltasse a morar com o pai após a separação; posteriormente mudou de idéia. Sua mãe conta que durante os anos de casamento o marido sempre bebeu, seguindo o exemplo do pai dele que também era etilista.

Todas as gestações dos filhos foram indesejadas, relata que não conseguia usar contraceptivos e, quando percebia que havia engravidado, pensava que seria mais um filho a sofrer e não sabia o que aconteceria à família.

Eles vivem de forma humilde, sendo a mãe e a irmã responsáveis pela renda familiar - trabalham como domésticas. Tiago e seus irmãos ficavam sob a responsabilidade do irmão que foi assassinado.

Após seu falecimento, Tiago apresentou mudanças bruscas de comportamento e foi encaminhado para avaliação psicológica por suspeita de retardo mental. Passado um período, voltou a ser capaz de desempenhar suas atividades, mas começou a apresentar comportamento agitado principalmente no núcleo escolar.

No convívio com a família, possui comportamento oscilante que vai do afeto e preocupação a acessos de agressividade injustificada. Essa oscilação está presente também no atendimento - por vezes executa as tarefas com interesse e disponibilidade, posteriormente torna-se irritadiço e oposicionista.

Possui dificuldade em apresentar projetos para o futuro, escolher áreas de interesse ou tecer críticas sobre seu comportamento, não consegue explicar as razões de seu envolvimento com os delitos praticados. 
Seu maior interesse é ficar na rua "brincando de pipa" ou com os amigos da mesma idade, algumas vezes comparece aos atendimentos acompanhado deles.

Sobre seu comportamento na escola, justifica que não lhe é dada a atenção devida, que os professores e alunos perseguem-no, ao tratá-lo de forma pejorativa.

Preocupa-se em não voltar a infracionar para evitar as situações que vivenciou após a apreensão, diz que ficar preso "é muito ruim".

Disse que se entristecia ao lembrar-se da morte do irmão de quem tem lembranças muito especiais, relata com perturbação as situações vividas pela família, recusa se a aprofundar nestes assuntos e a falar de sua tristeza. Nesses momentos, pede para mudar de assunto, fica agitado e falta no encontro posterior.

Lembra chorando quando ele e os irmãos foram obrigados a agredir o pai para contê-lo e se culpa por isso, diz que "nunca queria ter feito aquilo".

Sugerimos a necessidade de manifestar esses sentimentos na terapia, a fim de que pudesse elaborar as perdas vivenciadas de sua infância. Prosseguiu no acompanhamento psicoterapêutico.

\section{Questionário Desiderativo}

$1+$ Passarinho : ficar livre

2 + Pé de Amora : gosto de comer amora

3 + é difícil (não responde mesmo após indução)

1 - Orangotango : é muito sem graça, esquisito

2 - Pé de goiaba : tem muito bicho dentro

3 - Quadro : Vive parado, não se mexe 


\section{Análise do Questionário Desiderativo}

No questionário Desiderativo de Tiago, percebemos a falha no uso da repressão básica com o bloqueio da Terceira Catexia Positiva, o que idica alguma impossibilidade de utilizar-se da simbolização demandada no teste, resposta 3+.

Percebemos também certa falha na segunda dissociação com a eleição nas catexias negativas de símbolos comumente vistos como positivos, o que denota certa dificuldade em discriminar aspectos rejeitados ou valorizados pelo Ego (resposta 2-).

A falha na utilização do mecanismo de racionalização , com elaborações incoerentes e auto-referenciadas. (resposta 2+ e 2-)

Existe a presença da ansiedade persecutória, a perda da distância emocional , esta última representando a falha no uso do mecanismo de identificação projetiva.(resposta 2- e $2+)$.

A resposta 2- indica um uso patológico do mecanismos de identificação introjetiva com a presença de um temor de que os objetos ruins o invadam.

A rejeição do macaco na resposta 1-, a valorização de aspectos ligados a ação e liberdade na resposta 1+ e a rejeição de aspectos ligados a passividade, na resposta 3-, indicam a presença de aspectos predominantemente depressivos com perda da distância emocional e temor da privação do contato com o objeto. 


\section{Desenhos - Estórias:}

D - E: 1

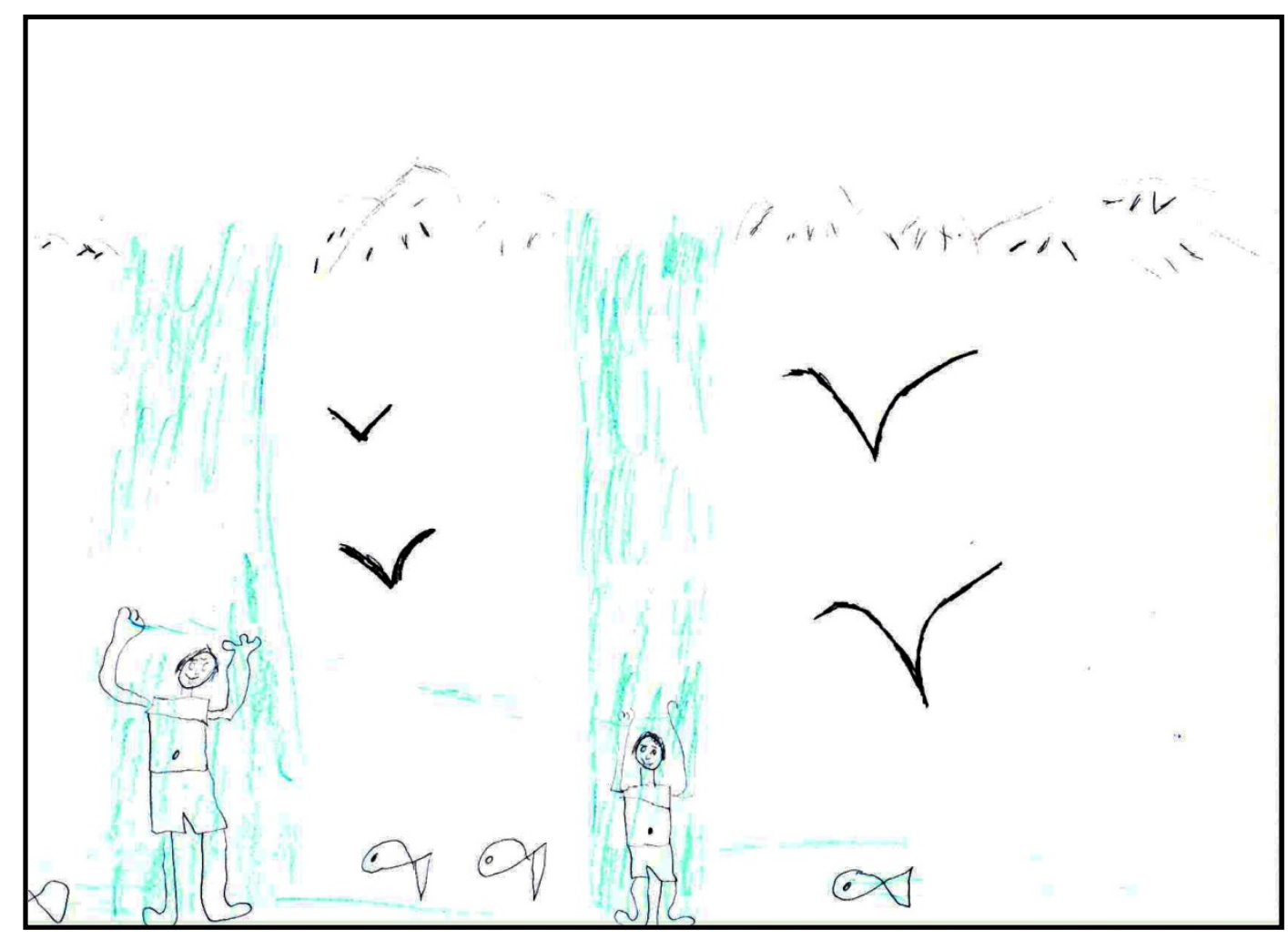

Título

: Não

Deu

(mesm

o após

estímul

os)

Eles estão se divertindo, um jogando água no outro. As gaivotas estão ao lado deles querendo o peixe e eles ficam assustados e os peixes ficam assustados. 

D - E 2:

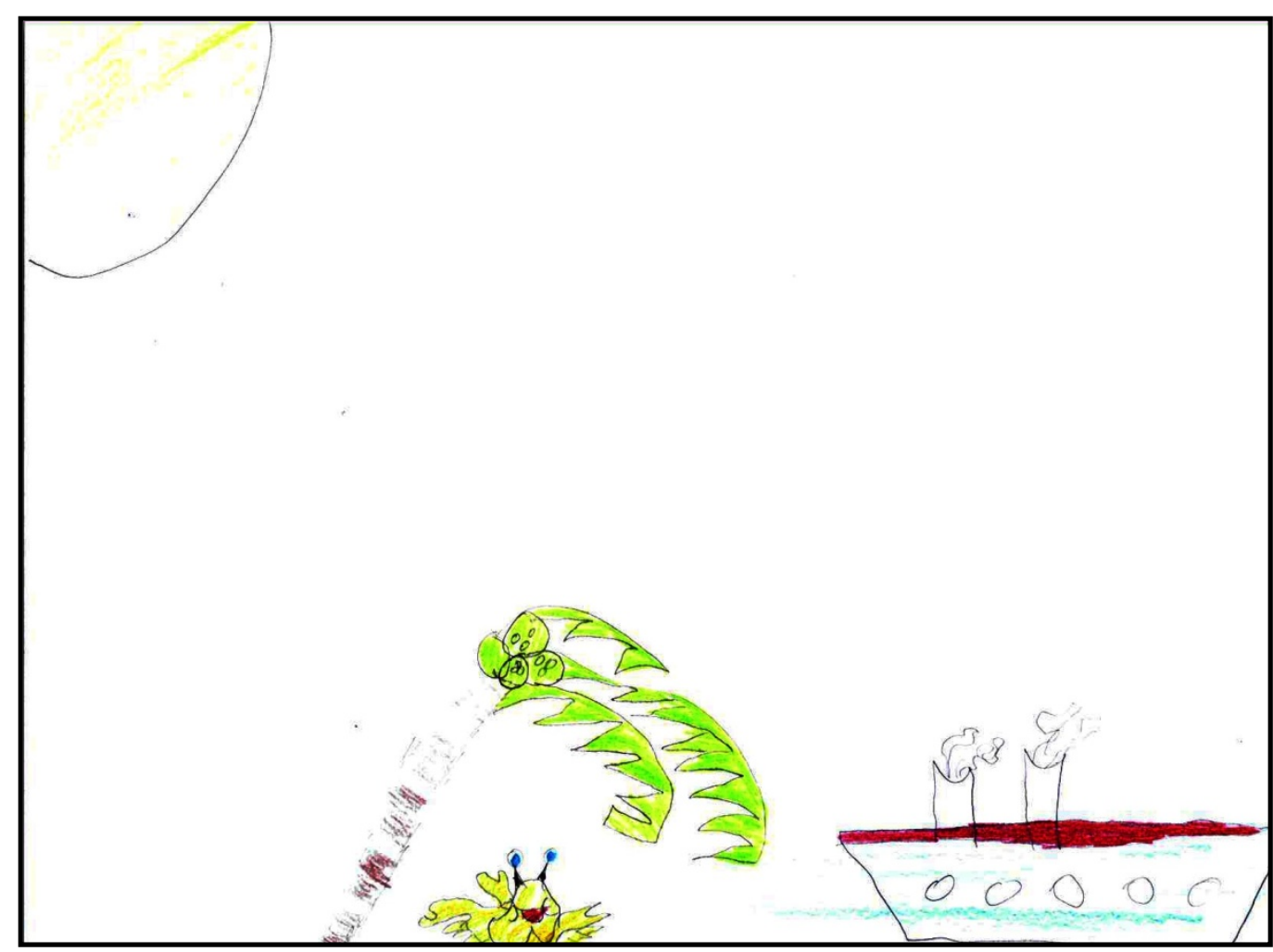

$\mathbf{T}$

ítulo:

Não

Deu

(mesm

o após

estímul

os)

O barco está se movimentando para a ilha e está batendo um vento muito forte no pé do coqueiro e como está muito sol, o caranguejo está embaixo do pé de coqueiro tomando sombra.

D - E 3 : 


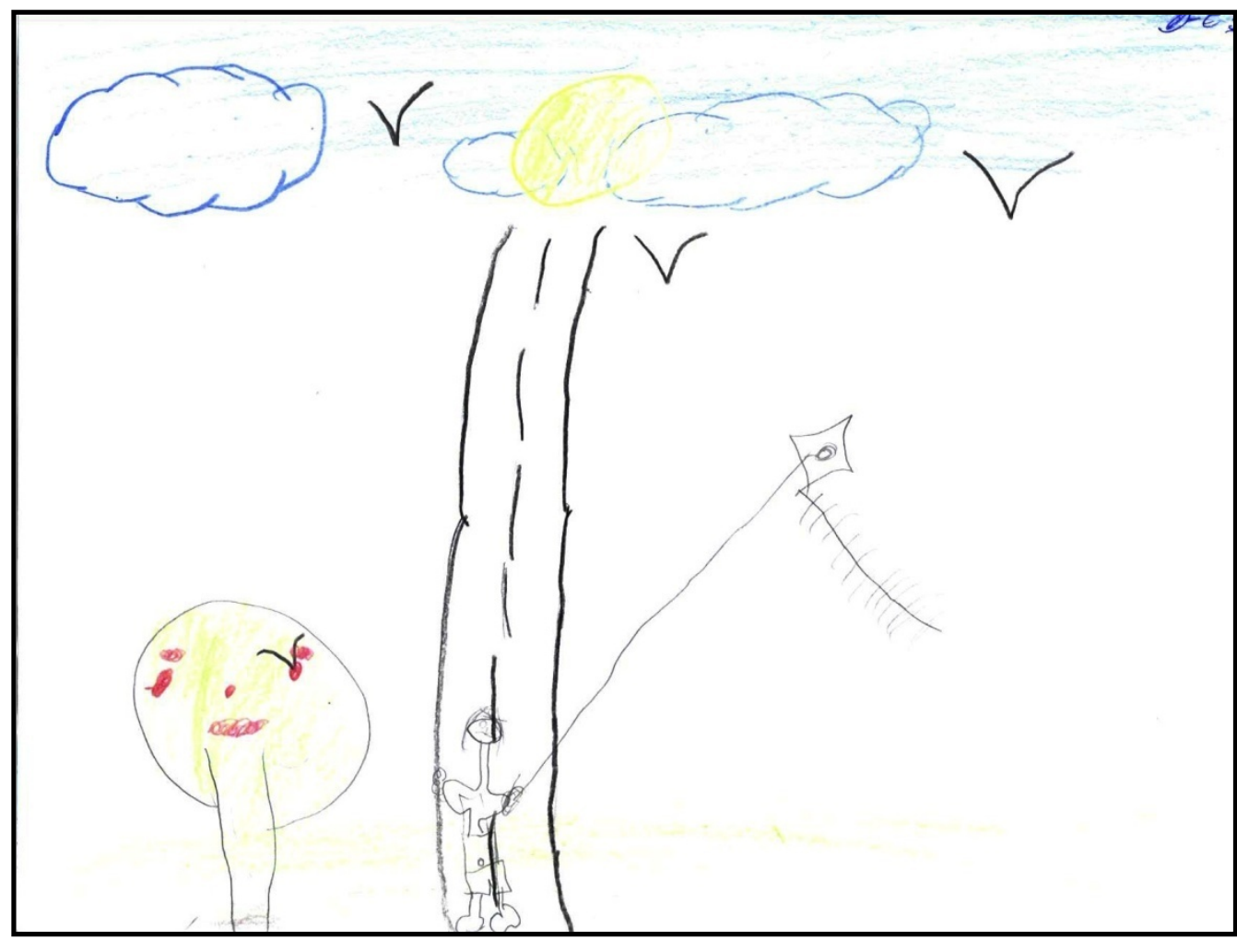

\begin{tabular}{|r|}
\hline ítulo \\
\hline Dia \\
\hline Feliz \\
do \\
\hline Emp \\
\hline inad \\
\hline or de \\
\hline Pipa.
\end{tabular}

O menininho está na estrada empinando pipa e tem um pássaro comendo maçã e o dia está muito quente e o ar está limpo, cheio de oxigênio.

D - E 4: 


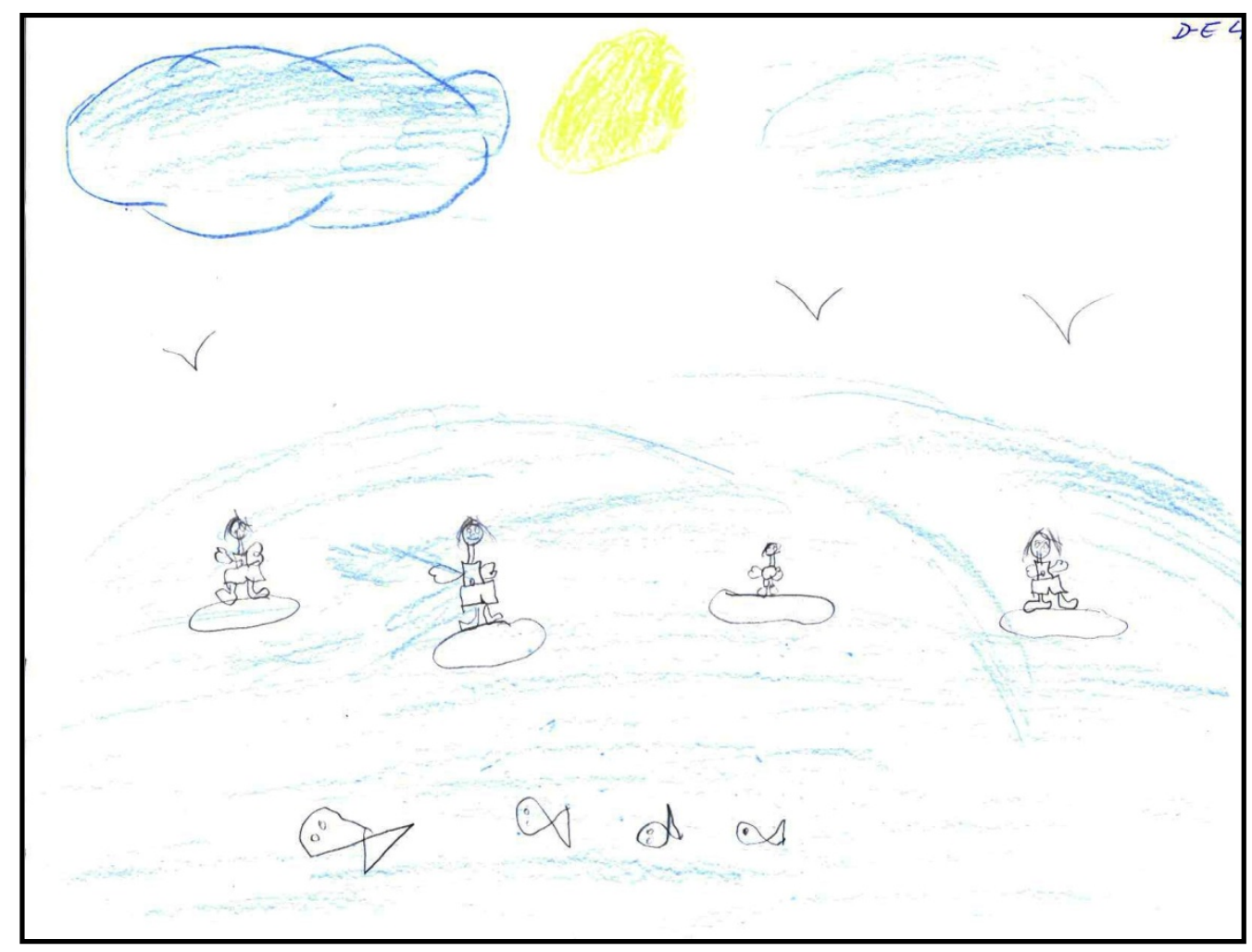

T

ítulo :

O

Melhor

Dia dos

Quatro

Garotos.

O

menino

surfando. Está o maior calorzão e o menino está se divertindo muito e ele queria amigos para ele surfar e apareceu mais três amigos para ele brincar.

E tinha muitas ondas e eles brincaram e se divertiram muito e as ondas estavam muito agitadas e os peixes estavam para lá e para cá agitados.

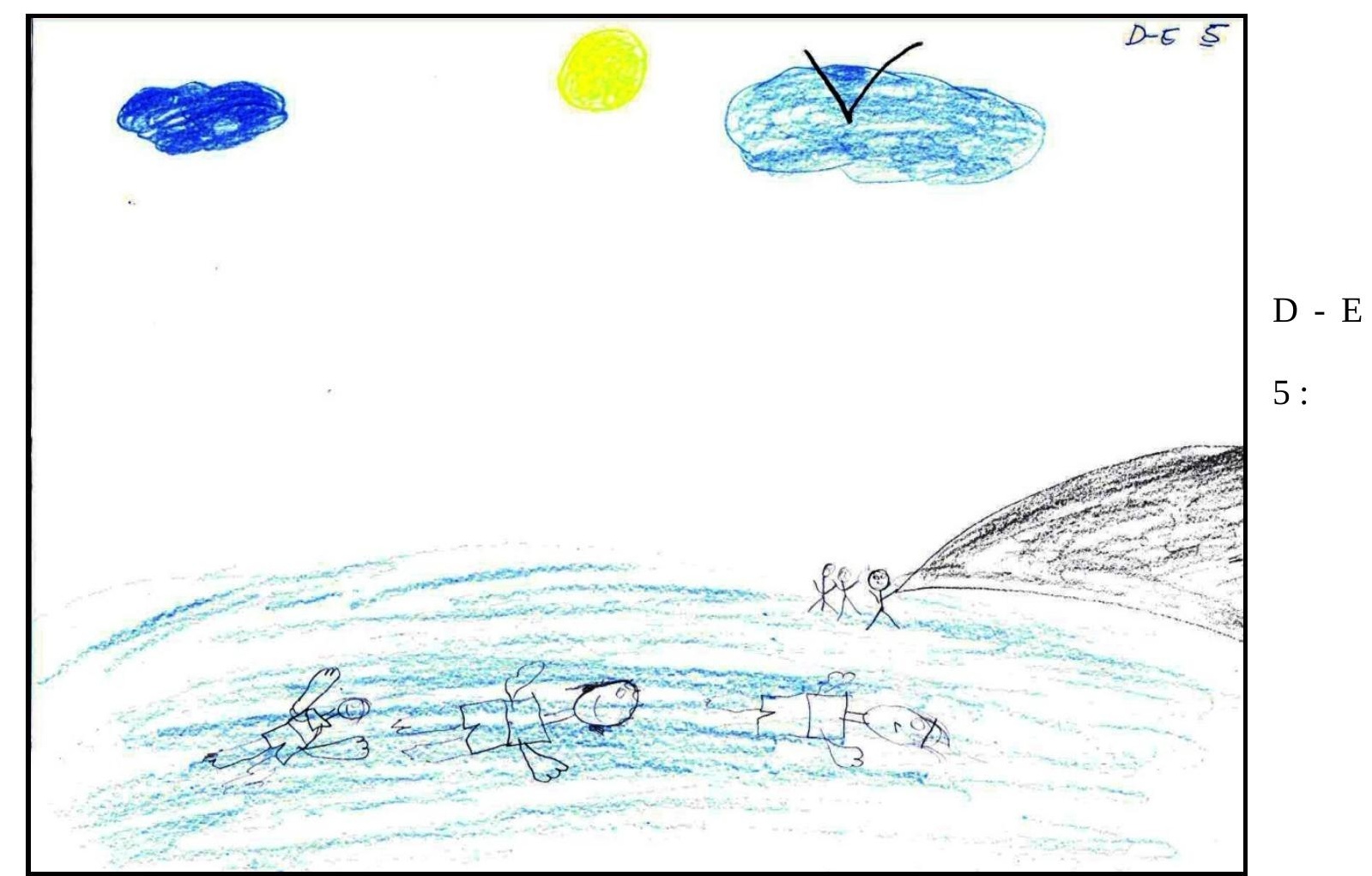




\section{Título : A União dos Três Nadadores}

Um moço está nadando de costas e mais dois colegas chegam para brincar também e os três se divertem até de tarde . Aí eles param de nadar e vão embora para suas casas. 


\section{Análise dos Desenhos - Estórias}

Os desenhos de Tiago apresentam-se bastante regredidos, o que pode estar expressando um modo primitivo para lidar com a realidade.

Os desenhos são todos coloridos, indicando a possibilidade de expressão emocional, os desenhos da figura humana aparecem de uma forma um tanto desorganizada, semelhante a figuras esquemáticas, o que nos faz pensar em uma certa regressão emocional .

As estórias são curtas e têm pouca riqueza de conteúdo, o que pode nos indicar pobreza no uso de recursos mentais superiores.

Predominam as atitudes de insegurança "... eles ficam assustados e os peixes ficam assustados..." , com necessidades de proteção e abrigo. Aparecem, também, atitudes que indicam necessidade de aceitação, proteção e êxito "... o dia feliz do empinador de pipa ..." . Estas aparecem como necessidades de suprir faltas básicas, com o desejo de afeto "... ele queria amigos ...".

Os sentimentos expressos estão relacionados à presença de conflitos "... O barco está se movimentando para ilha e está batendo muito, muito forte no pé do coqueiro ..." .

Aparecem figuras positivas, mas elas carecem de força e surgem as ansiedades paranóides "... As gaivotas estão ao lado deles querendo o peixe e eles ficam assustados e os peixes ficam assustados ... ".

Nos desenhos, o sujeito usa bastante a borracha e, em todas as estórias, usa uma expressão indicando o término da mesma "só isso" e "acabou". Esse tipo de expressão pode estar sugerindo o uso de mecanismos de repressão, este mecanismo associado à busca 
pela satisfação de suas necessidades básicas pode estar indicando uma tentativa de resolução dos conflitos.

De uma forma geral , conforme já foi indicado, são produções características de uma certa 'infantilização' e uma regressão a estágios primitivos do desenvolvimento, não há a predominância de impulsos hostis, inclusive com a presença de amigos e iguais.

Nas produções ficam marcantes as ansiedades paranóides e a busca de um prazer pelo prazer, de forma primária e demonstrando imaturidade. A ênfase em situações prazerosas pode estar representando, também, o uso de defesas maníacas , inclusive como contraponto à presença de estados depressivos subjacentes.

\section{Reflexão sobre o caso}

Tiago é proveniente de um ambiente familiar hostil e agressivo onde a violência e atitudes anti-sociais são banalizadas, podemos perceber isso através do comportamento de seu pai e do envolvimento de três de seus irmãos em atos infracionais.

Em uma fase importante de seu desenvolvimento, sofreu uma significativa perda com conseqüências emocionais marcantes e não elaboradas, parecendo haver algum sentimento de culpa ou fantasia de responsabilidade, pois há idealização deste irmão e , provavelmente, algum nível de identificação com este.

A suspeita de retardo mental na primeira infância e posteriormente seu comportamento irritadiço e agitado são indicativos da precocidade das vivências emocionais traumáticas, que levam a um estado depressivo, confirmado nos dois procedimentos. 
Assim como se confirma pela presença no Desenho-Estória de traços regredidos e necessidade de suprir faltas básicas.

O uso predominante de mecanismos maníacos confirma a aparente dificuldade em lidar com a tristeza profunda e as marcas de suas vivências do passado que o levam a tentar não entrar em contato , na relação psicoterapêutica, com estas situações.

$\mathrm{O}$ ato infracional e seu comportamento agitado parecem se caracterizar como uma expressão máxima da busca de resolução desta situação que lhe causa angústia e tristeza, além de ser uma tentativa de solicitar ajuda e expressar um conflito dos valores do Ego.

Ele busca um referencial de limite, não encontra em sua mãe que está enfraquecida e nem em seu pai que é uma presença negativa. A necessidade de manter seus pais juntos demonstra uma fantasia de responsabilidade pela quebra do vínculo.

Sua agressividade não é integrada, pois surge de forma repentina e incoerente, não há uma reflexão ou elaboração sobre seus atos.

Tiago vive um processo de elaboração de lutos relacionado a perdas e não há elementos para lidar com essa elaboração de forma efetiva, nem sequer há suporte ambiental para tanto.

Ele precisa elaborar esses lutos e conflitos, bem como deve ser oferecida intervenção no ambiente familiar. 


\subsection{João}

João foi encaminhado à psicoterapia, pela educadora, por contar com determinação judicial para tanto.

A educadora realizou vários agendamentos aos quais João não comparecia, apresentava-se resistente ao cumprimento da medida, a participar do processo psicoterápico e a retornar ao núcleo escolar.

Após diversas tentativas, um dia ele compareceu no horário que lhe foi agendado.

Possui 16 anos, mas apresenta características físicas de um menino, trajava-se muito bem, demonstrando cuidado com a aparência.

Foi apresentado à psicóloga e entrou na sala sem lhe prestar-lhe muita atenção, jogou-se na poltrona e com fala mansa e compassada iniciou sua história.

Relatava tudo como se a história não lhe pertencesse, sem grande envolvimento emocional ou vínculo afetivo. Começou dizendo que havia sido apreendido por roubo de um veículo, passado um período na FEBEM e liberado para cumprimento de Liberdade Assistida.

Não se detinha a detalhes, mas fazia questão de dizer que havia roubado outras vezes e planejava um grande roubo a carga com o envolvimento de pessoas com status na vida criminal.

Quando estimulado a aprofundar-se no assunto, conta que começou sua prática delitiva através de furtos de produtos de supermercado, o que ele considera uma atitude típica de qualquer moleque.

Continuou dizendo que, com o tempo, devido à situação da família ter piorado, buscou roubar coisas de maior valor até chegar ao roubo do veículo. Nesta época conheceu 
outras pessoas envolvidas na criminalidade, todas o alertaram quanto ao risco que corria, mas ele acreditou que valeria a pena .

Diz que não se arrepende de nada e não sabe se deixará de roubar, conta tudo com certo orgulho e satisfação, diz ser "bandido", nestes momentos encara a psicóloga e observa suas reações, sempre de forma tranqüila.

Em outros atendimentos marcados com muita dificuldade, porque ele dificilmente comparecia, continuou seu relato, mas mantinha-se sempre distante.

Sua mãe adotiva compareceu espontaneamente e contou-nos sua história de vida, buscando orientação.

Ela se mostrava emotiva, afirmando ser impotente diante da situação, dizendo que sabe que não consegue controlar o filho, mas "que sempre vai amá-lo independente do que ele fizer".

Descreve João como agressivo, distante e contrário a qualquer tentativa de aproximação e diálogo, inclusive , "que é muito difícil amar um filho como ele".

João é filho adotivo e único, foi dado a ela após seu nascimento e jamais teve contato com sua mãe biológica. Foi criado então por ela e seu companheiro como filho legítimo.

Em sua primeira infância, o casal se separou, o pai adotivo tomou rumo desconhecido e nunca voltou a procurá-los.

A mãe, obrigada a trabalhar, o deixava-o com um casal conhecido que não tinha filhos e que se dedicava a ele como se fosse seu. João passou a tratá-los como padrinhos.

Assim ele dividia seu tempo entre as duas famílias e todos eram responsáveis por sua educação. 
Havia discrepância entre os dois ambientes, pois de um lado a mãe adotiva vivia de forma humilde em uma favela e lhe dava uma educação condescendente, o casal de padrinhos tratavam-o de forma mais rígida e com maiores condições financeiras.

Quando João estava com dez anos, sua tia materna lhe disse a verdade sobre sua adoção. A mãe não consegue justificar o fato a não ser pela vontade desta em lhe fazer maldades.

Desde então, João se tornou "revoltado", segundo ela houve uma mudança de comportamento, ele dizia que havia sido enganado e não aceitava o fato de ter sido abandonado pela mãe biológica.

Depois de dois anos, o casal de padrinhos decidiu mudar de estado, depois de certa indecisão, João optou por morar com a mãe, o casal não aceitou e após a partida não os procurou mais.

João foi expulso de várias escolas por seu comportamento agressivo com seus colegas e professores, durante os atendimentos ele diz que pretende voltar a estudar, mas reconhece ter dificuldades, não consegue ficar parado, interrompeu os estudos na sexta série do ensino fundamental.

Essas situações precederam o envolvimento gradativo de João em atos infracionais, bem como o uso de drogas como a maconha e a cocaína.

Durante o processo psicodiagnóstico fazíamos intervenções no sentido de apontar a relação existente entre as perdas sofridas e seu comportamento, tentando estimulá-lo a expressar seus sentimentos criando um ambiente favorável.

Parecia-nos inconveniente a realização de interpretações, mas quanto mais tentávamos nos aproximar, mais ele recuava. 
João compareceu a dois atendimentos, abandonou o processo psicoterapêutico, recusou-se a se inserir num núcleo escolar e voltou às infrações.

Tanto a psicóloga, como a educadora da medida não conseguiram realizar novo contato com ele.

\section{Questionário Desiderativo}

1+ Cachorro: depois do homem é que está mais perto

2+ Árvore: faz sombra e bate vento nela

3+ Espelho: gosto de espelho

1- Barata bicho nojento, não gosto de barata

2- Verdura não queria ser comido por ninguém

3- Estátua: não gosto de estátua.

\section{Análise do Questionário Desiderativo}

No Questionário Desiderativo de João, percebemos o sucesso na $1^{\circ}$ e $2^{\circ}$ Dissociação Instrumental, onde ele consegue realizar a simbolização, discriminando fantasia da realidade, bem como discriminar aspectos valorizados e rejeitados pelo Ego. 
O que verificamos é a perda de distância emocional com os objetos, onde as elaborações são feitas de uma forma autocentrada (respostas 3+,1- e 3-)

Na resposta 1+, a escolha do símbolo cachorro foi feita com referência à sua proximidade com o humano em um movimento narcísico.

Percebemos uma maior adequação nas primeiras respostas. Ao longo do teste, com o incremento da angústia, ele vai se tornando mais narcísico e não consegue usar as defesas adequadas.

Nas elaborações fica marcante a auto referência, com a perda da distância emocional , indicando um fracasso no uso da identificação projetiva.

Há também uma falha na racionalização, pois as elaborações estão assentadas em critérios subjetivos.

Tanto no movimento global do teste quanto na qualidade das respostas, percebemos a presença da ansiedade persecutória. (resposta 2-)

A escolha dos objetos frios, duros e insensíveis (respostas 3+ e 3-) denota uma distância emocional, bem como um movimento narcísico de auto-referência , presença de impulsos orais de incorporação, afastamento da ligação afetiva, e uso de defesas como a dissociação e o isolamento apontam para o predomínio de traços esquizóides do funcionamento psíquico. 


\section{Desenho - Estória:}

\section{D-E 1}

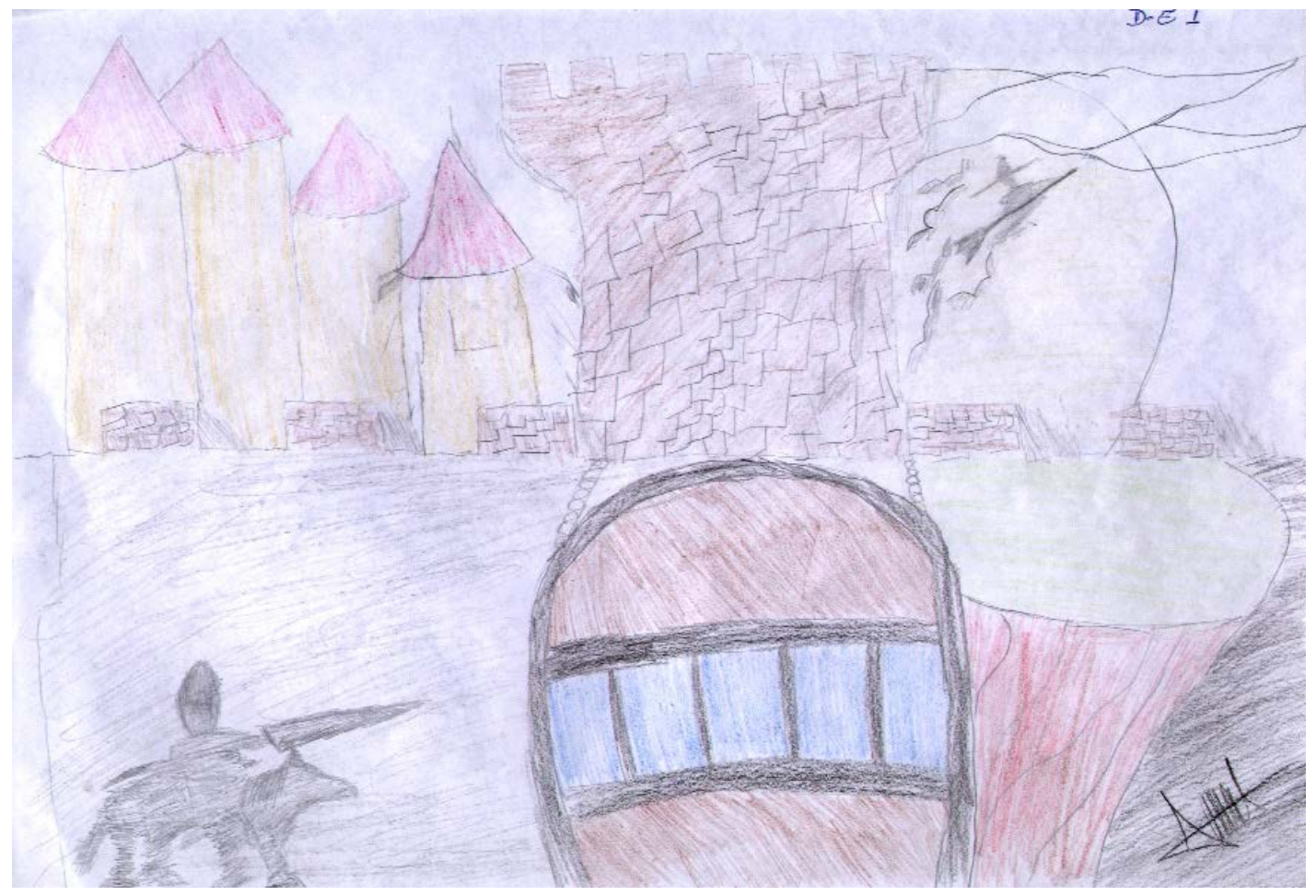

Título : Castelo Mal-Assombrado

Um cavaleiro morava dentro de um castelo, lá dentro tinha um monte de bruxas e de morcegos. 


\section{Análise dos Desenhos - Estórias}

João conseguiu somente realizar uma unidade de produção de D-E, o que denota sua resistência a se submeter ao procedimento e colaborar ou entrar em contato com seus conteúdos emocionais.

Tal aspecto parece também estar relacionado a dados da entrevista, na qual percebemos que ele procura se defender , mantendo uma distância emocional.

Os aspectos gráficos do desenho corroboram a hipótese acima, já que no "Castelo Mal Assombrado" se destaca a porta, que é feita em traçado mais forte e firme e é maior do que os outros detalhes do desenho.

Na sua produção, observamos a demonstração da agressividade e a preocupação em defender-se, já que João desenha um cavaleiro com uma lança.

Esse aspecto parece estar relacionado ao modo como ele percebe seu ambiente e seu mundo interno, isto é, de forma hostil, ameaçadora, como desprotetor e agressivo.

O modo como João descreve o ambiente do interior do "castelo" assemelha-se ao ambiente em que o mesmo sempre viveu, onde ele teve de se "armar" de recursos para se defender.

Esses traços podem estar indicando a existência de aspectos psicopáticos no funcionamento psíquico deste sujeito, bem como podem estar mascarando uma certa sensação de impotência para lidar com os aspectos agressivos e ameaçadores do ambiente. 
Na análise dos aspectos de conteúdo da estória, como atitude básica aparece a oposição, com traços de hostilidade, e também aparecem outras figuras significativas vistas de forma negativa, "um monte de bruxa e morcego".

Os sentimentos que surgem são os derivados do instinto de morte, com aspectos destrutivos, "o castelo mal assombrado".

Do mesmo modo, as tendências são destrutivas e os impulsos são também destrutivos.

As ansiedades que prevalecem são as paranóides, já que o ambiente é visto como hostil e ameaçador.

O principal mecanismo de defesa utilizado é a projeção, já que João parece projetar na sua produção as dificuldades e o modo como percebeu o ambiente em que vive, desenha um cavaleiro que morava num castelo com um monte de bruxas e de morcegos.

\section{Reflexão sobre o caso}

João tem dificuldade em comparecer aos atendimentos, possui uma falta de esperança. Ele busca o caminho da delinqüência e a marginalidade aparece como conseqüência.

Suas ligações afetivas com pessoas que lhe eram queridas quebraram-se deixando nele a marca da rejeição. Isso fica claro quando ele disse que roubava porque era revoltado com a vida.

Seu histórico de vida se faz na convivência em dois ambientes diferentes: o materno, que é caracterizado pela indulgência e privação; e dos padrinhos, caracterizado pelo estabelecimento de limites. 
Os padrinhos não suportam a escolha dele em ficar com sua mãe e o rejeitam, cortando todos os vínculos, João não consegue lidar com essa situação.

A mãe possui discurso e comportamento ambíguos, oscilando entre rejeição e superproteção, mantém um vínculo não confiável permeado de mentiras e insegurança.

Essa rejeição da mãe adotiva só reforça o abandono sofrido pela mãe biológica.

Os roubos inicialmente aconteceram no sentido de buscar o objeto perdido, sua mãe, e posteriormente vai perdendo a esperança tornando-se cada vez mais dissociado e construindo-se um falso self onipotente para lidar com as ameaças deste ambiente desestruturado.

João possui um funcionamento predominantemente esquizóide, com presença de ansiedades persecutórias e um tipo de relação narcísica, com a presença de um mundo interno povoado de objetos hostis e ameaçadores.

Esses dados surgem nos dois procedimentos e confirmam a história clínica, justificando a agressividade voltada para o ambiente como uma projeção do mundo interno.

A ausência de culpa, associada a seu funcionamento psíquico, demonstra um quadro mórbido, indicando a vida delinqüencial como resultado da estrutura de um self patológico. 


\subsection{Mateus}

Mateus foi encaminhado pela educadora por ter dificuldades em aproxima-se dele, que se mantém distante e fala pouco.

Foi com esta mesma postura que compareceu ao atendimento, olhar distante e fala monossilábica, não respondendo às intervenções realizadas. Esta resistência se faz notar, inclusive, nas informações mais básicas sobre sua vida.

Ele cumpre medida de Liberdade Assistida há seis meses por roubo com arma de brinquedo, trata-se de sua primeira passagem pela FEBEM.

Em relação a essa vivência, diz "que foi muito ruim e ficou muito feliz em ter recebido a liberdade assistida porque não queria ficar preso". Relata que a medida tem the ajudado dando orientação e oportunidades, fez curso de computação e voltou a estudar, atualmente está matriculado na oitava série do ensino fundamental.

Sua família é formada pela mãe, uma irmã de vinte e dois anos e uma sobrinha de um ano. O relacionamento da família é descrito como "muito bom e tranqüilo", conta que seus pais são separados desde que tinha sete anos, não sabe o motivo da separação, apenas que brigavam muito, foi melhor que tenham separado.

Não tem contato com o pai , só lembra a imagem e que ele era etilista. Diz não sentir saudade.

A mãe teve outro relacionamento, seu companheiro também era etilista , mas o tratava bem, não gostava de trabalhar, não deu certo e eles também se separaram.

Mateus afirma ter bom relacionamento com a mãe a acha ótima, nunca fez nada de ruim e sempre o tratou bem. A família vive da pensão que a mãe recebe e do trabalho de doméstica da irmã, ele se diz feliz em casa. 
Conta que já experimentou maconha, sua mãe soube e ficou muito magoada, pois não aceita que ele use drogas, então nunca mais usou. Quando foi apreendido, relata que a mãe ficou triste, queria que ele saísse de lá, ele ficou triste com a tristeza da mãe e decidiu não infracionar mais.

Quanto ao ato infracional, explica que não premeditou e não entende por que o fez "que nem passa pela cabeça fazer de novo", agora quer trabalhar, ficar com a família e comprar uma moto, porém não sabe como conseguir tudo isso. Não há alguma área que lhe desperte interesse e não tem planos estabelecidos para seu futuro.

Nos seus relatos não há profundidade, fala sempre em gírias, demonstra dificuldade

em falar de si, diz que "não gosta de ficar pensando sobre as coisas, prefere apenas viver", "porque nunca se sabe o que vai ser no outro dia", faz pouco contato emocional, reage mecanicamente às solicitações do psicólogo, parece evitar contato emocional com as tarefas e com as solicitações.

Após três atendimentos pede para não voltar mais, porque o incomoda ter que falar dele.

\section{Questionário Desiderativo}

1+ Leão: é bonito, forte.

2+ Quadro: paisagem pra todo mundo ver.

3+ Flor ( Vitória Régia): é bonita, tem destaque.

1- Macaco: é estranho.

2- Espinho de flor: tem veneno, machuca as vistas. 
3- Arma: tem maldade nela.

\section{Análise do Questionário Desiderativo}

No Questionário Desiderativo de Mateus, percebemos certa falha na segunda dissociação com certa dificuldade em discriminar entre o que é rejeitado ou valorizado pelo objeto (respostas 1 - e 2 -) .

Há falha no uso do mecanismo de racionalização, pois ele não consegue desenvolver as elaborações, apesar das escolhas de símbolos elaborados, as respostas são simples, denotando um bloqueio da racionalização por impacto emocional.

Nas Catexias Positivas, há uma inversão dos reinos, mais uma vez demonstrando falha na $2^{\circ}$ dissociação, mas não marcante o suficiente como um indicador patológico.

Percebemos a presença de ansiedade persecutória, principalmente na qualidade das respostas ( 2 - e 3 -).

Há escolha de objetos por seu impacto estético (respostas 1+, 2+, 3+ e 1-), a rejeição do macaco por seus aspectos grotescos que surgem na $1^{\circ}$ Catexia Negativa, a racionalização desiderativa bloqueada, uso de linguagem simples com símbolos ricos e condensados, a presença de um símbolo fálico ameaçado na resposta 3-, o uso de defesas como sedução, repressão e conversão indicam a presença predominantemente de traços histéricos do funcionamento psíquico. 
Desenhos - Estórias:

D - E: 1

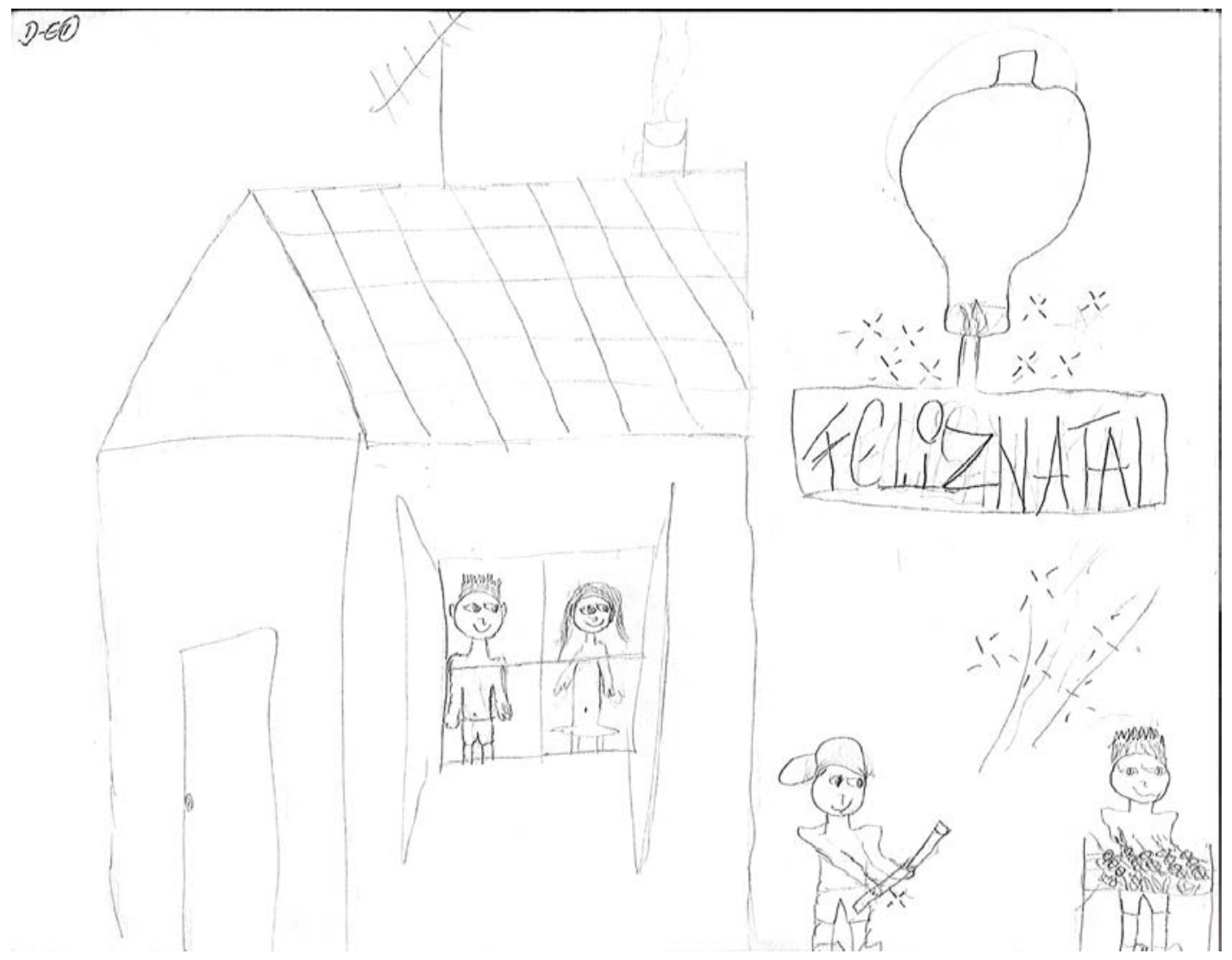

Título: O Meu Natal

Estava com a minha família, feliz, os amigos. Todo mundo feliz. Cada um faz uma coisa , um faz churrasco , outros solta fogos e outros lá dentro brincando. 
D - E: 2

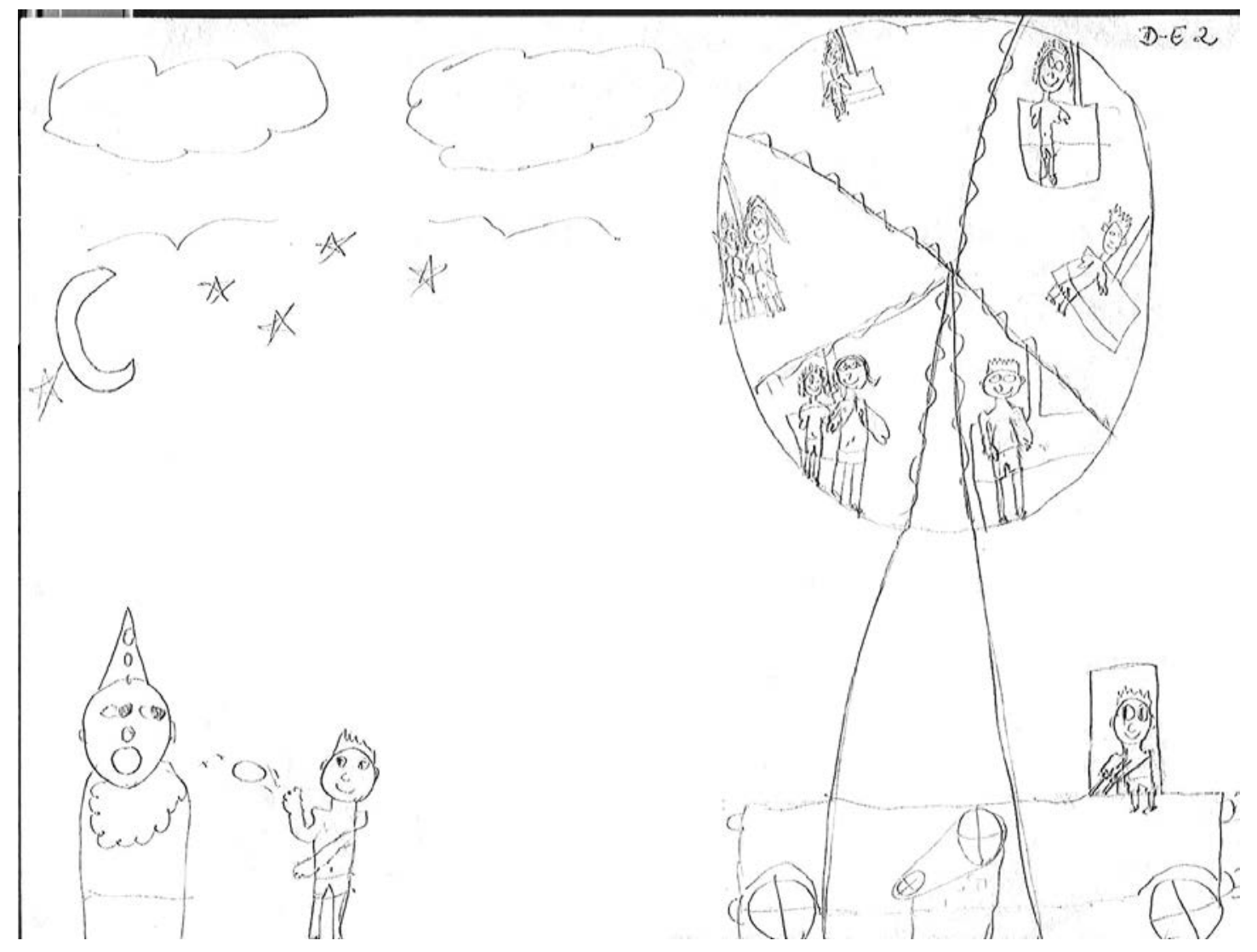

\section{Título: Alegria}

A história do parquinho, quando eu era pequeno, eu gostava. Todo mundo está brincando. Só. 
D - E: 3

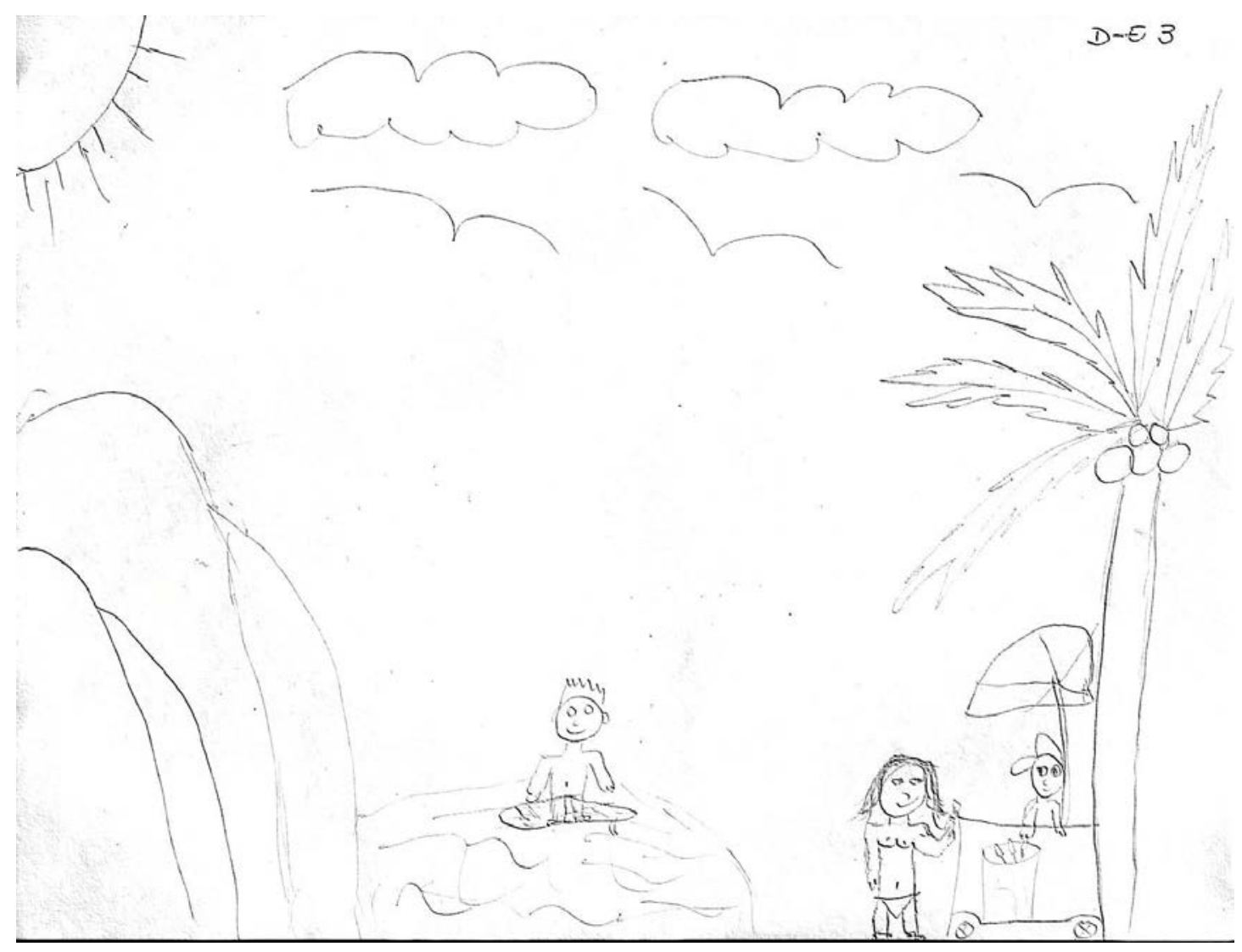

Titulo: As Férias

Acho legal praia, descansar, curtir. Só. 


\section{Análise dos Desenhos - Estórias}

Os desenhos de Mateus são bastante regredidos e incompatíveis com a faixa etária, o que pode estar indicando uma forma primitiva para lidar com a realidade.

Há também uso excessivo da borracha, expressando a utilização de mecanismos de repressão e resistência, na realização da tarefa.

Nas unidades de produção, este adolescente aponta desejos de proteção e abrigo, sendo que a mãe aparece como uma figura positiva. Esta identificação positiva com a figura materna também revela-se na entrevista.

Como atitude básica destaca-se a identificação positiva, “Estava com minha família, feliz, os amigos”.

As figuras que aparecem são positivas, como familiares e amigos, o que denota uma boa identificação no relacionamento familiar; do mesmo modo, os sentimentos expressos estão relacionados ao instinto de vida, com alegria, “todo mundo feliz”.

As tendências são as construtivas, as mais evoluídas, com necessidade de realização e autonomia e os impulsos são os amorosos. As ansiedades presentes são do tipo depressivas. O mecanismo de defesa presente é o da repressão e projeção

Observamos, de um modo geral, que Mateus procura evitar contato emocional com as tarefas , já que não aprofunda os temas das estórias e as mesmas têm pouco conteúdo. 


\section{Reflexão sobre o caso}

Mateus possui uma comunicação difícil, é fechado sendo este o motivo pelo qual é encaminhado ao acompanhamento psicoterápico.

Esse comportamento talvez manifeste uma organização defensiva que evita o contato com conteúdos emocionais não elaborados.

O isolamento, então, pode ser uma forma de não lidar com as situações vividas. Este bloqueio impede a elaboração de conteúdos emocionais e o surgimento das falhas no self.

Há, inclusive, uma percepção consciente deste movimento , pois, quando questionado sobre os motivos desse isolamento, sua resposta é que é uma forma de não lidar com o sofrimento.

Esse bloqueio do contato com conteúdos emocionais leva a um estancamento no processo maturacional e surge um modo de funcionamento mais regredido que impede , inclusive, o uso saudável do mecanismo de racionalização, como vemos na produção do Questionário Desiderativo.

O excesso de sentimentos alegres e prazerosos que surge na produção do Desenho Estória não representa a inexistência de conflito , mas sim, a impossibilidade de contato com estes.

Há aspectos positivos, já que está freqüentando um núcleo escolar, o que de alguma forma indica preservação de expectativa em relação ao seu futuro.

Preocupa-se também com os sentimentos de sua mãe e utiliza uma arma de brinquedo, o que denota uma preocupação com o outro e o cuidado em não feri-lo. 
Há presença predominante da ansiedade depressiva, impulsos amorosos, sentimentos ligados ao instinto de vida e figuras positivas, que demonstram a presença de uma personalidade predominantemente sadia, com bom prognóstico.

Seria necessário, portanto, uma intervenção terapêutica adequada para "quebrar" esse bloqueio emocional, permitir a expressão dos conflitos e elaboração dos sentimentos derivados deste.

A infração pode ter ocorrido em razão desta impossibilidade de elaboração com única via de expressão de que algo não ia bem. 


\subsection{Lucas}

Lucas é encaminhado ao atendimento a pedido de sua educadora que acredita ser favorável a sua vivência. Compareceu após diversas remarcações, teve muita dificuldade em iniciar o contato, mantém uma postura defensiva. Depois do estímulo do psicólogo, iniciou sua história.

Ele tem dezesseis anos, possui porte físico compatível a sua idade e veste- se de forma muito humilde.

Trata-se de sua primeira apreensão, apesar de ter realizado outros delitos; roubava pedestres quando percebia que tinham dinheiro, começou com furtos até conseguir uma arma emprestada e realizar o roubo.

Acredita que suas atitudes são justificadas pela situação em que vive, prefere roubar a ver sua família passar por necessidades e tem a dificuldade em aceitar o fato de não poder adquirir bens, comenta ser difícil ver outras pessoas com coisas que ele não possui, gostaria de ter carro, moto e roupas de marca.

Tinha alguns amigos "envolvidos no crime", que lhe davam conselhos para que não fizesse o mesmo, mas resolveu arriscar, "não tinha nada a perder".

Não tem intenção de voltar a roubar já que aprendeu a lição e agora vê que as coisas não são como pensava e que a maioria de seus amigos estão mortos. Mesmo assim, não garante isso, pois, se passar por necessidades não sabe como vai administrar esse fato.

Sua família é formada pela mãe, padrasto e quatro irmãos de vinte, dezenove, quinze e treze anos, estes todos desempregados. Moram em uma casa de madeira com quatro cômodos 
O pai abandonou a família quando ele tinha quatro anos, não se lembra dele, somente sabe que era etilista e drogadito. Não tem interesse em vê-lo, acha-o um “pilantra”, batia na mãe e nos irmãos e foi detido por roubo.

A mãe constituiu nova união há quatro anos, Lucas acha que o padrasto é "boa pessoa" para sua mãe e irmãos. Ele provê a família trabalhando como pedreiro e o adolescente mantém bom relacionamento com ele por considerá-lo trabalhador.

Disse que, depois de sua apreensão, o relacionamento com a família melhorou, porque passou também a ter mais convivência com eles e a respeitar as orientações de sua mãe, que está mais atenta a seu comportamento e lhe dá mais atenção. Refere-se a ela sempre com carinho e, quando soube de sua apreensão, ficou "abismada".

Foi usuário de drogas, maconha e cocaína, iniciou aos quinze anos e interrompeu o uso após sua apreensão, tomou consciência que ela ia afundá-lo.

Lucas fala muito de suas privações e que a família vive de forma precária, insiste muito na necessidade de trabalhar, conta ser a única ajuda que realmente quer receber.

Demonstra educação e cordialidade apesar de seu vocabulário ter muitas gírias, diz que se sente diferente, que as pessoas têm preconceito contra ele e que algumas o julgam como "boa pessoa", outros o julgam como " bandido".

Acredita ter os dois lados dentro dele mas gostaria que só vissem o lado bom. Às vezes tem pensamentos ruins que o incomodam.

Em um momento da sessão diz que não gosta de psicólogos porque querem mexer na mente das pessoas e não gosta que façam isso com ele, acha que falar do seu passado não vai mudá-lo e que ninguém pode ajudar.

Interrompeu os estudos no final de 2002 quando cursava a sétima série do ensino fundamental, no momento busca vaga na rede de ensino público, tem interesse pela carreira 
de mecânico, gostaria muito de fazer um curso profissionalizante nessa área, mas acha que não tem condições.

Após quatro atendimentos começa a faltar e não retorna mais.

\section{Questionário Desiderativo}

1+ PÁSSARO: poder voar e ver todo mundo

2+ CHAVE: Para abrir portas para todo mundo entrar

3+ FLOR: Para presentear todas as pessoas que merecem

1- RATO: Para ninguém me desprezar

2- COFRE: Não gostaria de carregar tanta coisa comigo

3- ESPINHO: não gostaria de machucar ninguém

\section{Análise do Questionário Desiderativo}

No Questionário Desiderativo de Lucas não surgem falhas na $1^{\circ}$ e $2^{\circ}$ dissociações, indicando que ele é capaz de utilizar-se de símbolos, ao discriminar fantasia da realidade e aspectos valorizados e rejeitados pelo Ego.

Percebemos porém as falhas na identificação projetiva , com perda de distância entre o símbolo e os aspectos representados, a ponto de as elaborações serem realizadas em $1^{\circ}$ pessoa. 
O uso da racionalização é adequado seguindo leis da lógica formal. O que percebemos pela qualidade das respostas é um temor da privação do contato com o objeto , uma preocupação em não machucar.

Como se o que ele tem de ruim ou agressivo saia para fora, prejudicando o objeto, e esse o castigue com o desprezo e a rejeição, há um temor do descontrole das fantasias sádicas. (respostas 1-,2- e 3-)

Assim, há uma tentativa de aplacar o objeto, convencendo da bondade do Ego (respostas 2+ e 3+).

Essas características indicam traços de funcionamento psíquico predominantemente depressivos, o que se percebe pela qualidade das respostas com a perda da distância emocional, rejeição dos objetos que destróem, temor pela privação do contato e rejeição emocional com a busca de ser querido.

A ambivalência chave - cofre nas respostas 2+ e 2- indica que é valorizada a possibilidade de acesso ao contato e rejeitado o que simboliza o fechamento para esse contato. 


\section{Desenhos - Estórias:}

D - E: 1

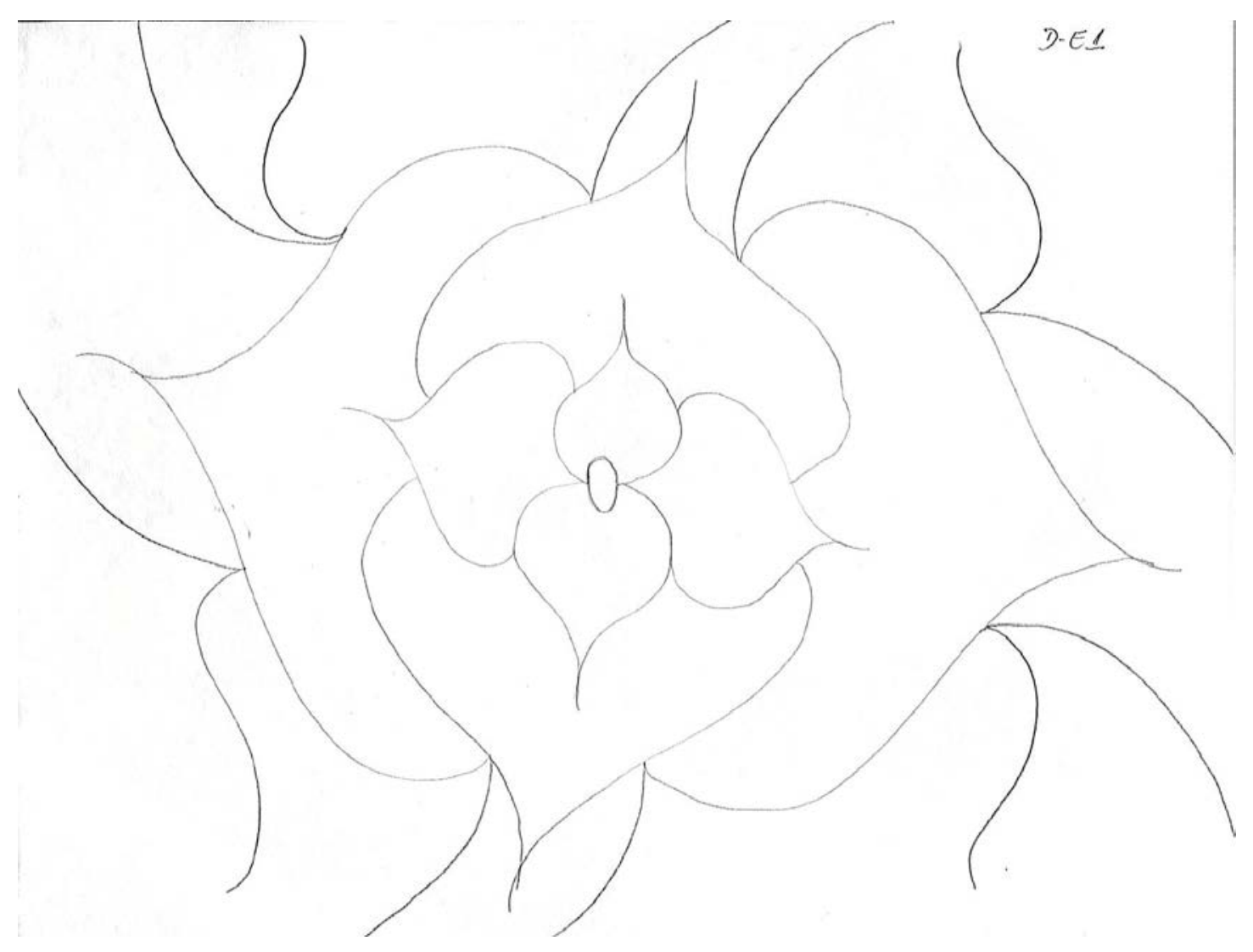

Título : A Rosa Bonita

Era uma rosa que se achava feia, porque, quando todo mundo passava por ela, olhava com olhar diferente.

Até que um dia ela descobriu dentro dela que ela não era feia, que era uma rosa bonita. 
D - E: 2

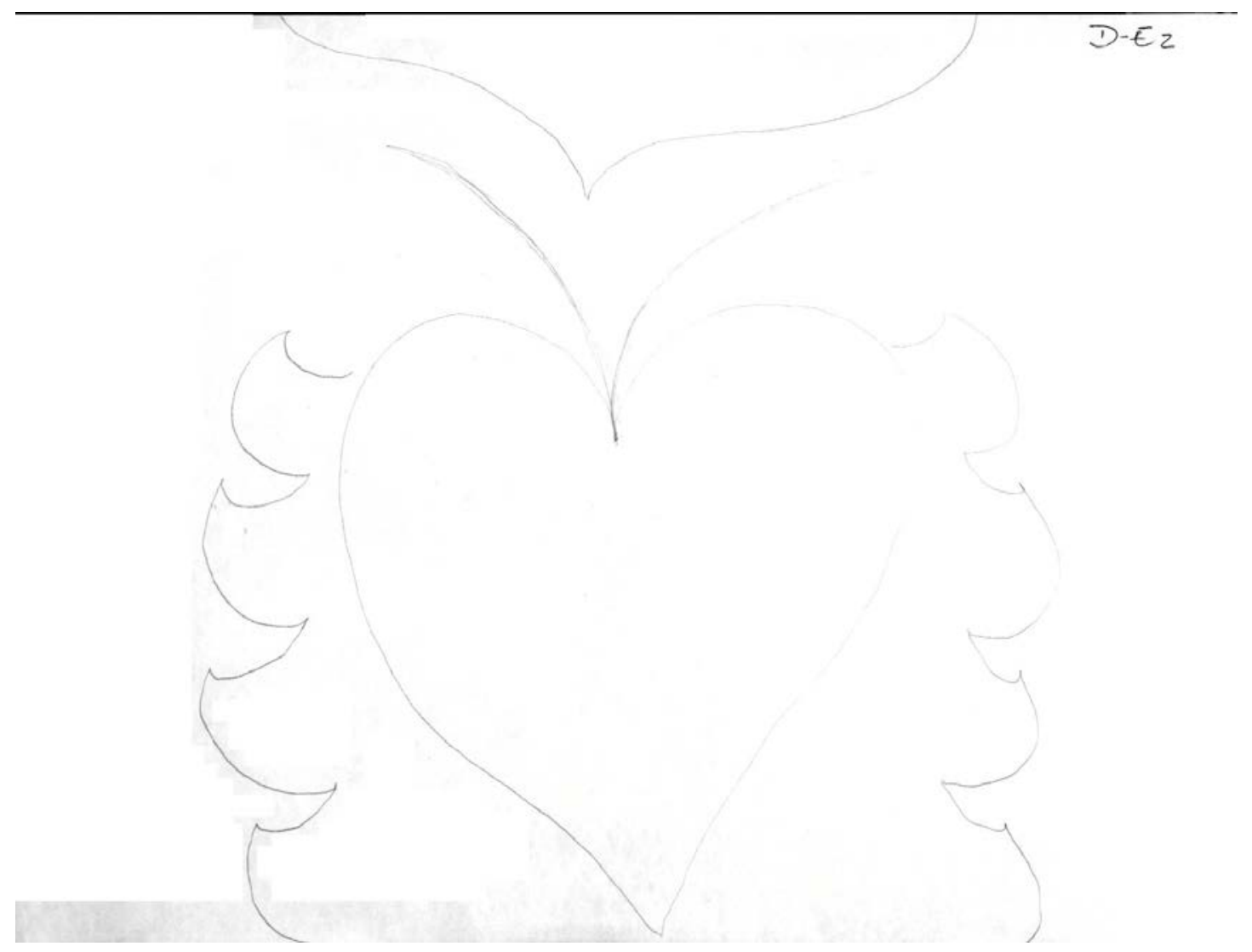

Título: Diferente Coração

Era um coração que se achava muito diferente dos outros porque parecia que ele tinha asas e antenas.

Ele vivia se perguntando por que ele tinha isso e os outros não tinham, até que um dia ele encontrou um coração igual a ele e esse coração disse para ele: quanto mais ele se enchia de amor, mais alguma coisa apareceria no corpo dele. 
D - E: 3

D-E 3
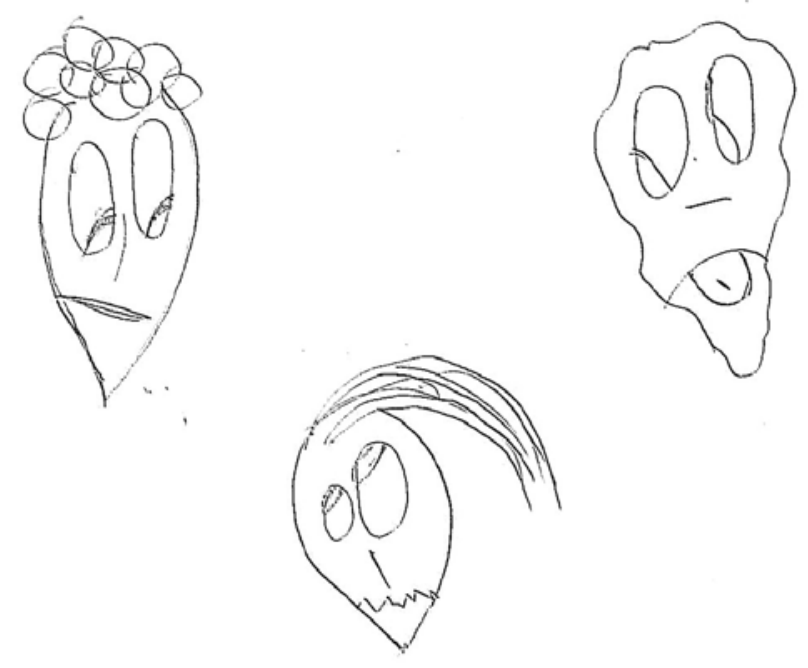

Título: A Cara Maluca

Eram 3 irmãos, eles se achavam muito feios e eles queriam ser diferentes, queriam ter outra cara.

Até que chegou uma pessoa e falou para eles se queriam mudar de cara, daí eles aceitaram e mudaram para uma cara melhor.

Cada um escolheu a cara de um artista famoso, só que eles perceberam que não estavam tendo sossego.

Depois eles se arrependeram e queriam a cara feia de volta.

Daí o cara que transformou cara para ficar mais bonito devolveu a cara deles e falou para eles nunca se igualar aos outros, tem que aceitar o que eles são. 
D - E: 4

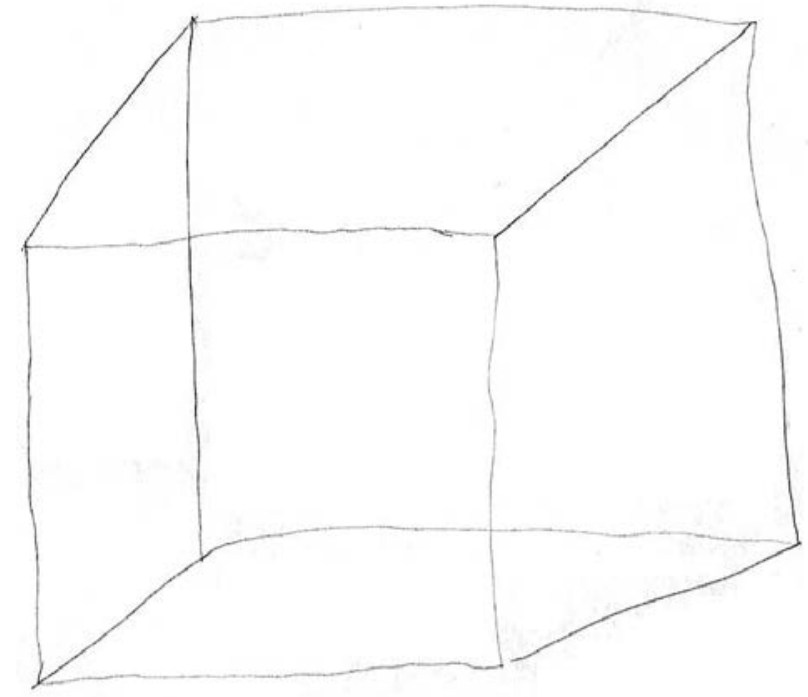

\section{Título: A Caixa Misteriosa}

Era um país que vivia cheio de guerra e era guerra pra cá e era guerra pra lá briga entre eles mesmo.

E eles não achavam uma solução para tudo isso.

Daí um certo dia, um país chamou para guerrear e eles foram, estavam uns de um lado e outros do outro.

Quando estavam correndo para brigar um contra o outro. Na hora de brigar eles barraram em uma caixa, daí essa caixa se abriu e ela mudou o pensamento de todos eles que estavam guerreando, eles não queriam mais saber de guerrear e seguiram a paz. 
D - E: 5

D.ES

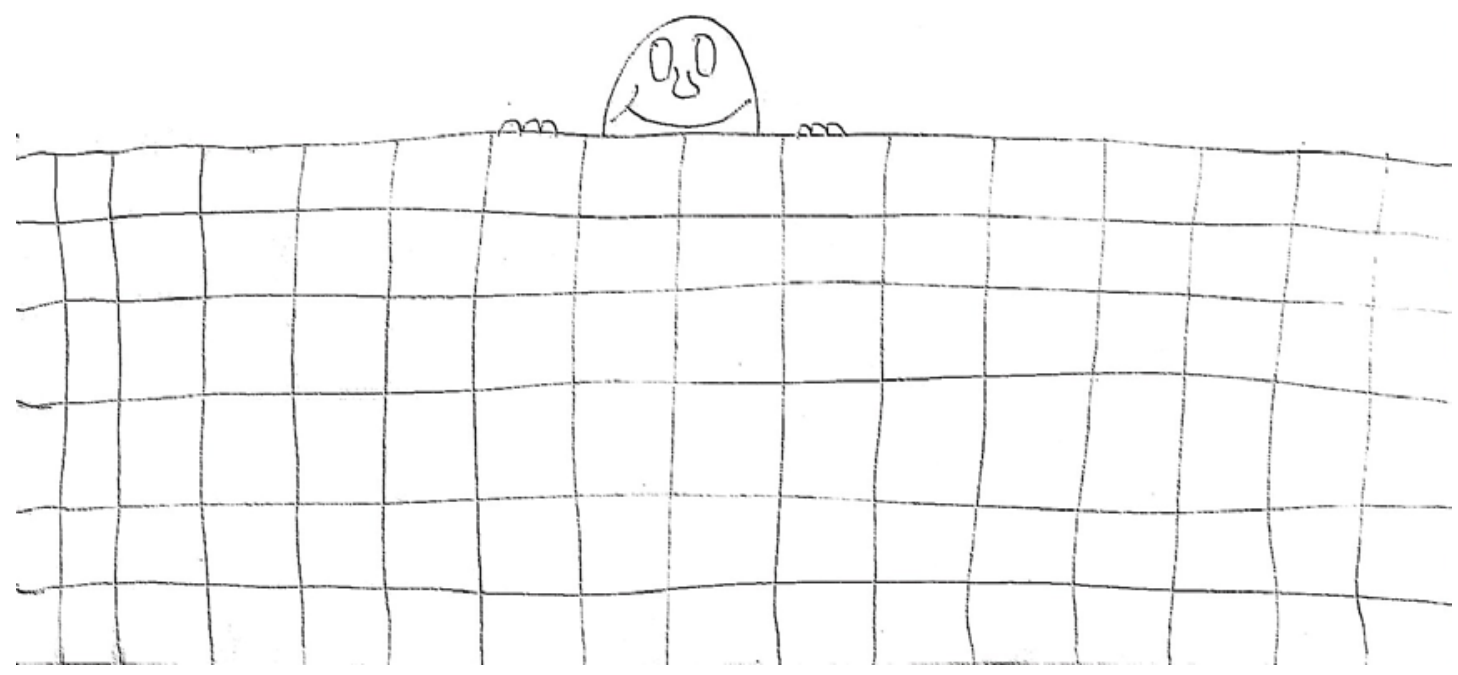

Título: O Espião

Era um cara que só vivia espionando os outros

A coisa que ele mais gostava era ficar olhando os outros .

Até que ele subiu no muro da casa de um vizinho e caiu e quebrou a perna.

Daí a mãe dele levou ele para o médico, engessou a perna e ele aprendeu que nunca mais ia olhar ninguém. 


\section{Análise dos Desenhos - Estórias}

Os desenhos de Lucas são bastante primitivos e regredidos. De um modo geral, suas estórias parecem retratar um conflito entre aquilo que se é, a aceitação desta condição e sobre aquilo que se deseja ser.

Os temas parecem se repetir e retratam sempre algo que não é aceito porque não é visto como bom ou bonito, a aceitação deste fato e a transformação do mesmo. Deste modo, o tema “aceitação” é freqüente nas estórias.

Nas estórias, fala também sobre um desejo de transformação no sentido de melhorar o relacionamento familiar.

As unidades de produção revelam uma boa identificação com a figura materna, o que corrobora os dados da entrevista. Por outro lado, na unidade, são revelados os conflitos em relação à figura paterna, o que foi descrito como uma "guerra” .

Assim, Lucas parece procurar constantemente uma solução para apaziguar seus sentimentos de ódio e os conflitos em relação ao pai.

No que se refere às atitudes básicas destacam-se a insegurança com necessidade de ajuda e proteção e, principalmente, a preocupação com a aceitação, D-E 2: “Era uma vez um coração que se achava muito diferente dos outros porque parecia que ele tinha asas e antenas. Ele vivia se perguntando porque ele tinha isso e os outros não tinham, até que um dia ele encontrou um coração igual a ele e esse coração disse para ele: quanto mais ele se enchia de amor, mais alguma coisa aparecia no corpo dele”.

As figuras são vistas como positivas, isto é, o relacionamento com os outros é de cooperação, colaboração e igualdade, “Daí a mãe dele levou ele para o médico...”. 
Os sentimentos referem-se aos derivados do conflito, D - E 4 : “Era um país que vivia cheio de guerra e era guerra pra cá e era guerra pra lá, briga entre eles mesmo..., daí eles não queria mais saber de guerrear e seguiram a paz”.

Como tendências e desejos encontramos a necessidade de suprir faltas básicas de afeto, abrigo, compreensão. Além disso, encontramos também as tendências construtivas com necessidade de cura, realização, autonomia e crescimento, D- E 3 : “Daí o cara que transformou a cara para ficar mais bonito devolveu a cara deles e falou para eles nunca se igualar aos outros, tem que aceitar o que eles são”.

As ansiedades presentes são as depressivas e o mecanismo de defesa utilizado é a projeção.

\section{Discussão com base nos dados obtidos}

Percebemos em Lucas uma experiência forte de inadequação de partes de si mesmo que se refletem em ambos os procedimentos e na entrevista clínica.

Parece haver uma percepção inconsciente de um lado muito ruim não integrado que pode se manifestar-se a qualquer momento, machucando o objeto externo e tendo como conseqüência a rejeição deste.

Assim, parece viver em uma tensão constante, tentando convencer o mundo e o próprio Ego de sua bondade. As suas vivências podem ter sido percebidas como retaliações, a manifestação deste lado repelido.

Possui uma auto-imagem negativa e há conflitos relacionados a sentimentos de inadequação. Existe uma dicotomia entre o que é bom ou mau, entre objetos bons ou maus, 
tanto no seu relato quanto nas suas produções, evidenciando uma impossibilidade de integrar duas faces no mesmo objeto. a inaceitação que vê , do mundo para com ele, é uma projeção de sua própria inaceitacão para com ele mesmo.

Existem elementos positivos em seu psiquismo , com tendências construtivas, desejos de proteção e abrigo, mas ele não se permite falar de seu passado. Os modelos referenciais que possui são negativos e há pouca esperança na qualidade do cuidado que será oferecido.

Diante disso, Lucas não tem mais medo, sente que não tem nada a perder, não vê mais saída para sua vida, perdeu a esperança e o sonho.

Lucas deseja que todos vejam seu lado bom, tem dificuldade com seu lado "bandido". Se pudesse enfrentar este seu lado, abriria o caminho para a transformação.

Seu relato nos mostra a dificuldade de um adolescente que vive em situação financeira precária, convive com as desigualdades sociais e que sente que ter uma melhor situação é importante, poderíamos dizer que este fator está relacionado à sua auto imagem distorcida e rebaixada.

O trabalho psicoterapêutico com Lucas deveria buscar a integração desses aspectos com o resgate de seu verdadeiro self e sua autenticidade. 


\subsection{Marcos}

Marcos possui 16 anos e foi encaminhado ao acompanhamento psicoterapêutico por determinação do juiz. Em todos os atendimentos foi sempre pontual, não faltava e estava sempre bem vestido, demonstrando certa vaidade.

Apesar de ser introspectivo, não tem dificuldade em se expressar, fala de sua vida de forma tranqüila e sem alteração emocional, demonstrando capacidade de compreensão e reflexão, faz críticas a seu comportamento, dizendo saber que fez mal para algumas pessoas, mas busca afastar-se emocionalmente das tarefas ou do que é relatado

Ele conta ter infracionado mais de uma vez, cometeu um roubo a um estabelecimento comercial e ficou em semiliberdade, depois foi inserido em Liberdade Assistida.

Diz que começou a roubar para “correr contra a lei, testar seus limites”. Não deseja mais roubar, porém, "não se sabe o dia de amanhã", hoje se fizesse seria por “ambição”.

Reside com sua irmã de quinze anos e seus avós em imóvel próprio, apesar de aposentado seu avô trabalha como vigilante em uma firma, diz que o relacionamento entre eles é bom, mas não tem muita amizade nem diálogo.

Sua mãe trabalha em uma igreja no setor de limpeza, seu pai fugiu quando ele era pequeno e só se lembra de que era pedreiro e de que os pais brigavam muito. O pai constituiu outra família e não fez mais contato .

Sua mãe constituiu outro relacionamento do qual teve oito filhos e sofre agressões.

Marcos conta que a mãe não tinha condições para criá-lo e entregou-o aos avós quando bebê, os outros filhos dela foram institucionalizados. Marcos não acha justificativas para mãe tê-lo abandonado com seus avós. 
Quando tinha doze anos, foi passar uma temporada na casa da mãe, desejava conhecê-la melhor, parou de estudar, fez amigos na rua e passou por privações alimentares, seu avô foi buscá-lo e nunca mais quis morar com ela, infelizmente já estava envolvido com o crime.

Nessa época diz ter ficado dividido, mas agora tem certeza de que deseja permanecer com seus avós.

Para ele sua mãe não tem responsabilidade, não lhe transmite segurança e o que ela fala é mentira e "para uma criança não se deve mentir”, quando ele era pequeno, ela prometia que iria visitá-lo e não aparecia, que ia ficar com ele e buscar seus irmãos nas instituições e não cumpria nada.

Aos seis anos foi agredido pelo padrasto, na época jurou que se vingaria, hoje diz que não fará nada, fala que a vida se encarregará de lhe dar o que merece, porque os seus filhos não gostam dele.

Marcos conta que passa muito tempo pensando sobre si e sobre sua vida, reconhece ter dificuldades em falar de seus sentimentos, principalmente se forem positivos, pois lhe parecem "assustadores", sempre que surgem sentimentos de amor, imediatamente surge uma grande preocupação com a rejeição e o abandono, já que tem a impressão de que esse sentimento será desprezado, como sua mãe o fez.

Durante todo o processo psicoterapêutico, o adolescente tem dificuldade em contar as histórias e desenhá-las, pede para copiar e depois pergunta se precisa realmente fazer aquilo, justifica que não lhe vem nada à cabeça, o que ocorreu depois que foi explicado a ele que isso ajudaria a conhecê-lo melhor. 
Atualmente está cursando o supletivo, tinha parado de estudar na sétima série do ensino fundamental para trabalhar, foi ajudante em um lava rápido, foi pintor, entregador de pizza, panfleteiro e ajudante de eletricista.

Diz que não quer ser rico, apenas bem de vida, não quer ter patrão, talvez será camelô. Continuou o processo psicoterapêutico até encerrar sua medida de Liberdade Assistida.

\section{Questionário Desiderativo}

1+ Leão : vive na selva, bonito, cercado de bichos, ele é o rei

2+ Eucalipto : bonito, verde, bem acabado, grande

3+ Cadeira : faz um bem tremendo, apara todo mundo e ninguém vê.

1- Gato ; gato é muito chato

2- Parede : é muito fria

3- ----------(Não respondeu mesmo após indução)

\section{Análise do Questionário Desiderativo}

No Questionário Desiderativo de Marcos, percebemos um declínio na elaboração das respostas evidenciado nas catexias negativas, até haver um bloqueio na última Catexia Negativa.

Esse bloqueio é relacionado à falha na repressão básica que permite o uso do simbolismo no teste, mas também podemos dizer que faz parte de um movimento de 
incremento da angústia, onde as defesas vão ficando mais primárias e o Ego mais fragilizado.

Percebemos também uma falha na racionalização, pois nas catexias negativas as elaborações seguem critérios subjetivos e não as leis da lógica formal, o que parece, também, estar relacionado ao incremento da angústia. (repostas 1- e 2-)

Surge um temor de não saber se defender. Há presença da ansiedade persecutória que se apresenta na análise global do teste, no declínio das defesas no decorrer das catexias.

A qualidade das respostas aponta para a presença de aspectos fóbicos no funcionamento psíquico, onde o leão é escolhido por sua majestade com a supressão de aspectos agressivos e a resposta da parede, onde há a supressão de estímulos emocionais.

Também há presença de traços histéricos nas respostas quando as escolhas são feitas em razão de seu impacto estético. (1+ e 2+)

Assim percebemos traços de funcionamento predominantemente histéricos com a utilização de defesa fóbica contra a ansiedade e culpa em um movimento de aproximação e afastamento dos objetos com a utilização de defesas como a rejeição, conversão e repressão.

Vemos porém partes preservadas de seu funcionamento psíquico, de alguma forma ele consegue se defender, as dificuldades surgem nas áreas de maior conflito. É positiva, também, a presença de traços depressivos quando da escolha dos símbolos, fazendo-se referência à sua utilidade. (resposta 3+).

\section{Desenho - Estória:}




\section{D-E: 1}

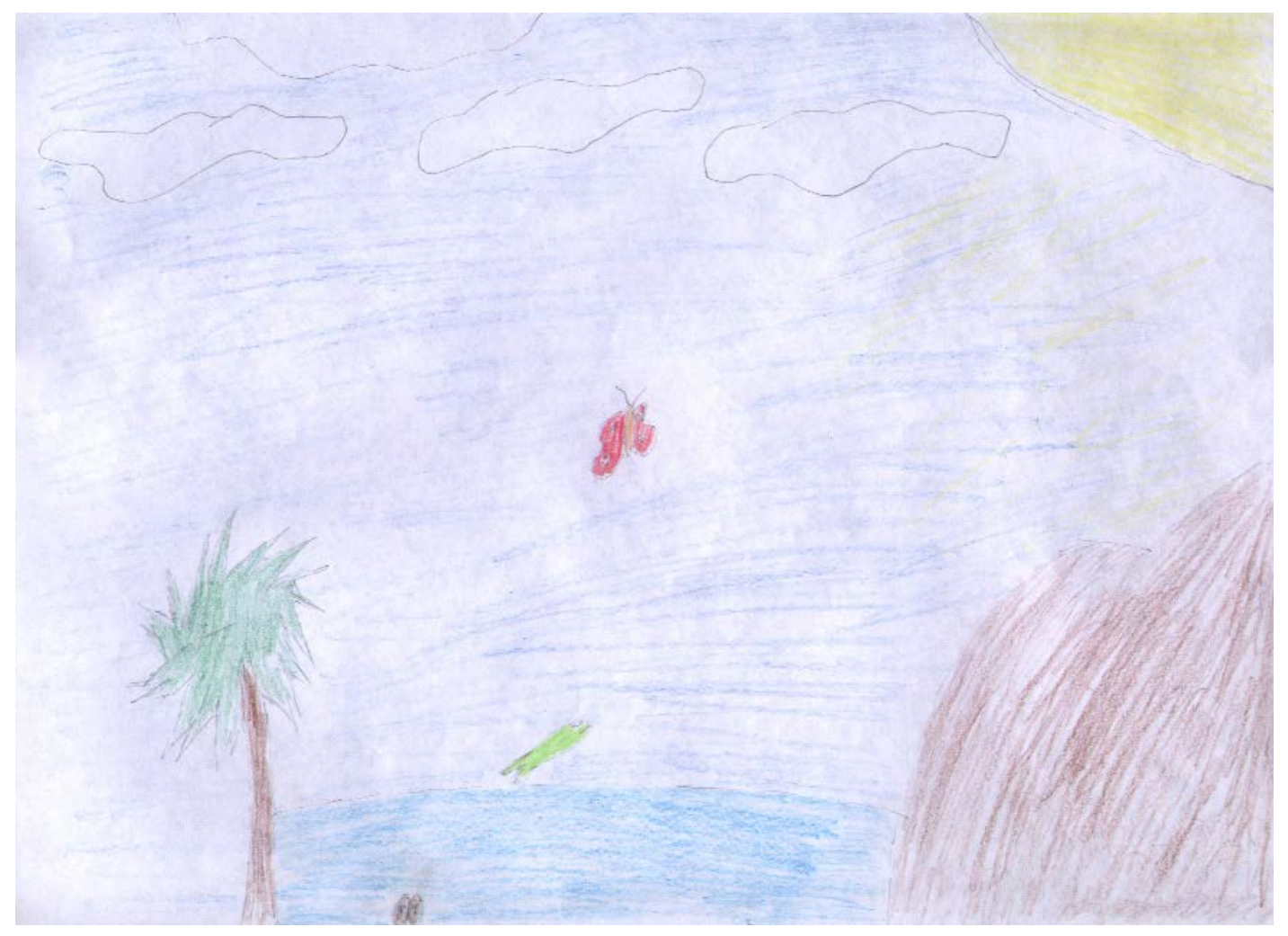

\section{Título: Paisagem Natural}

Era uma vez, como começa toda a história, não tem muito o que dizer, desenhei uma paisagem, uma praia, está fazendo sol, as borboletas estão voando, os peixes pulando, os cocos estão mergulhando porque caíram do coqueiro. O ambiente está sossegado. Só isso. 
D - E: 2

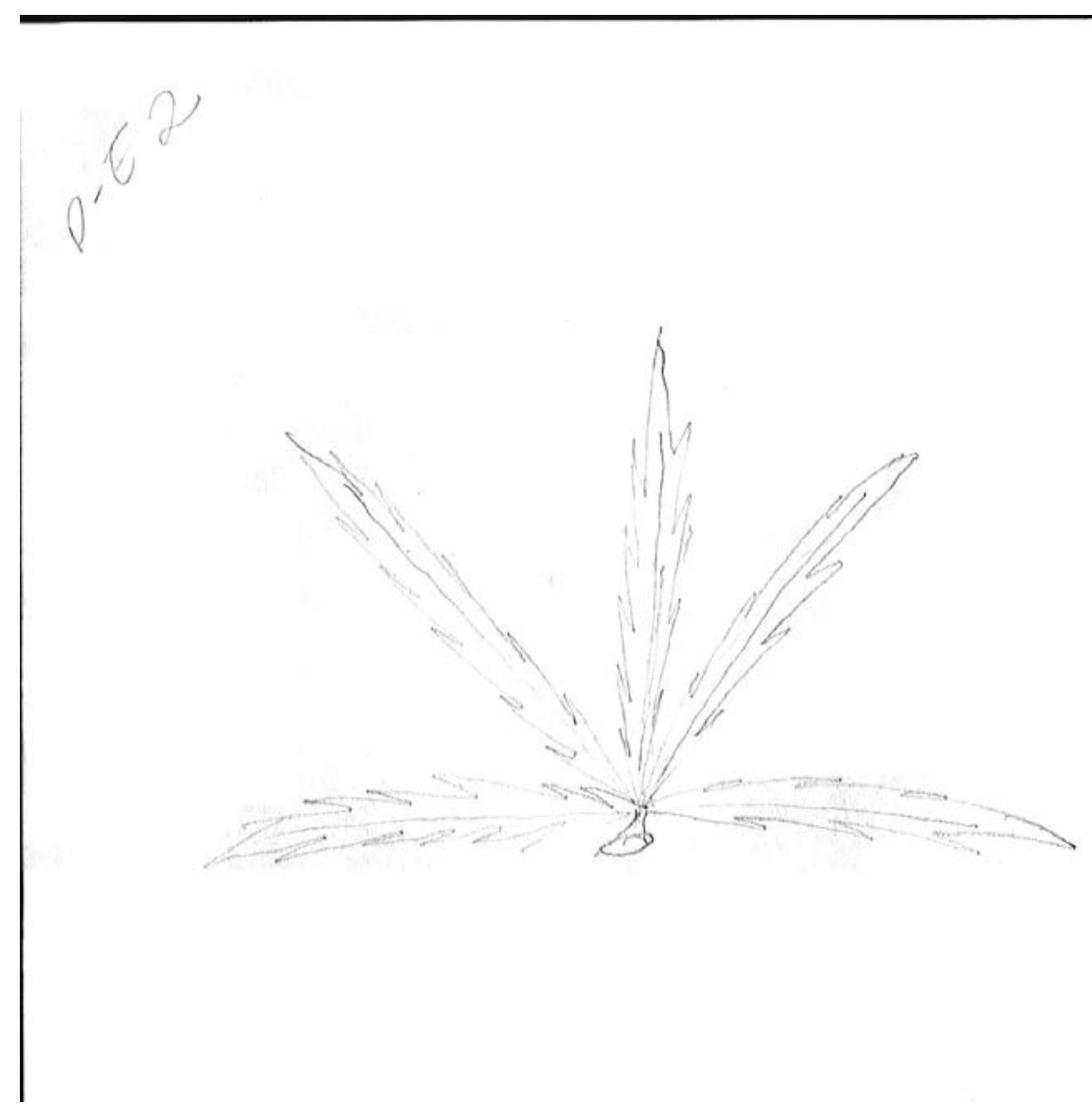

\section{Título: Folhas}

O que eu vou falar de uma folha? Folha de maconha, ela tem 5 pontinhas, ela deixa muito louco, tem muito dela na Jamaica, é proibido, no Brasil é proibido, de certa forma é proibido mas em todo lugar tem, só. Não é comum as pessoas desenharem folha de maconha, né? 
D - E: 3
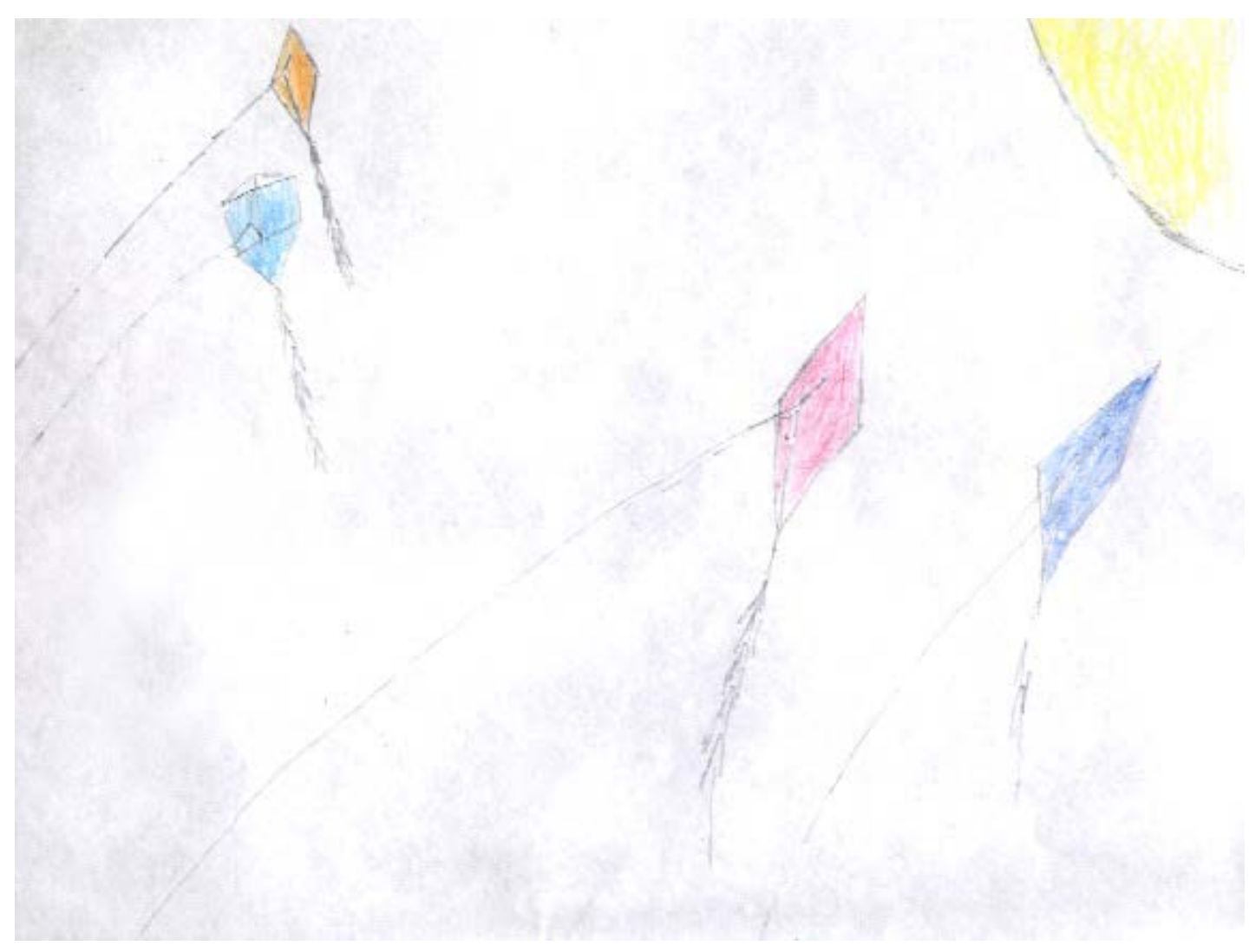

\section{Título: Pipas}

Vou desenhar uns pipas, está chegando a época mesmo, também tem um sol, difícil é a história, vou dizer como se faz uma pipa só pra ter o que falar: precisa de duas varetas, uma folha de seda, saco plástico, coloca as duas varetas em forma de cruz, envergando as pontas para baixo com a linha e cola a folha de seda, fazer o estirante, passar cerol na linha, solta e vê se consegue cortar os outros.

Quando eu era menor, não saia da laje, gastava todo dinheiro, meu avô não gostava , agora meu negócio é sair, que é o que eu gosto de fazer. 
Eu soltava pipa na época em que eu não podia sair para a rua, não conhecia o mundo, nem imaginava que um dia eu estaria conversando com a Sra. e que teria sido preso.

Eu saí de um mundo para outro, meu mundo era um e de um tempo pra cá eu conheci o outro lado da moeda e eu tenho que decidir qual é o melhor, tem um momento em que você tem que ver o que é o melhor para você, o que se encaixa melhor. 
D - E: 4

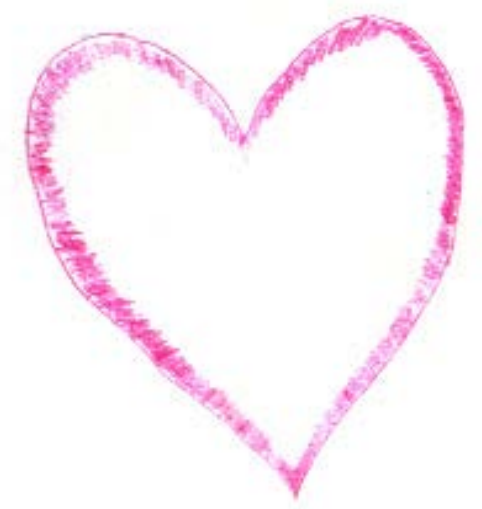

\section{Título : Sentimento}

Sentimento não é algo que possa ser explicado, mas sim algo que as pessoas tem por outras pessoas, por objetos, sei lá por algo que gostem, algo que sintam, que vale a pena lutar, algo que ajude alcançar seus objetivos. 
D - E: 5
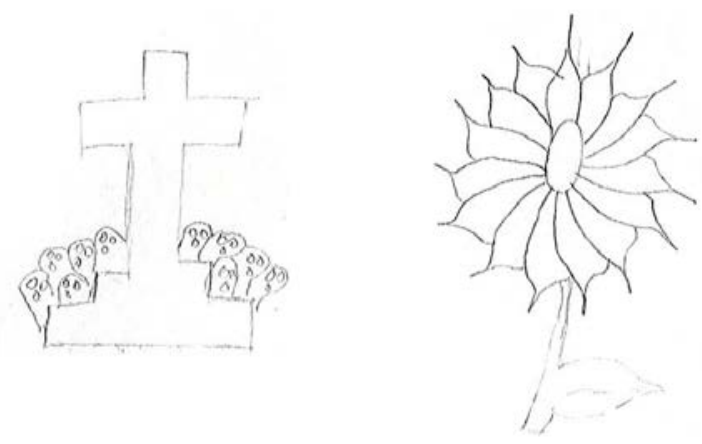

\section{Título: A Luz Através das Sombras}

Quando você nasce destinado a uma finalidade, mesmo que tente mudar correr por outros caminhos, será muito difícil, você encontrará muitos obstáculos no seu caminho, neste momento você pensará no seu passado, nas coisas ruins que fizeram, por outro lado pensará nas pessoas que ama, em seus objetivos, a partir deste momento ficará ao seu critério escolher se prefere correr pelas sombras ou pela luz, espero que o que decidir seja o melhor, e que não chegue a se arrepender. 


\section{Análise dos Desenhos - Estórias}

Os Desenhos - Estórias de Marcos parecem revelar sua percepção e temores em relação ao mundo interno e externo, sendo sentidos como hostis e desprotetores.

Esse adolescente transmite a idéia de que não confia nas pessoas, o que corrobora os dados da entrevista em relação ao que sente no grupo familiar. Marcos sente-se ameaçado ao ter de expor seus sentimentos e estes serem desprezados.

Existe uso constante de um mecanismo de resistência para contar a estória, já que , na maioria das vezes, descreve o desenho feito e não desenvolve um tema sobre o mesmo, D-E:1 “...desenhei uma paisagem, uma praia, está fazendo sol...”.

Podemos inferir que este aspecto está ligado a uma dificuldade em se envolver emocionalmente nos relacionamentos e nas situações e na tentativa de se manter distante neste aspecto, no sentido de proteger-se.

Os desenhos são coloridos, mas contém um traçado fraco e descontínuo, indicando sua fragilidade para lidar com as questões que o envolvem. As figuras, então, ficam pouco definidas e os limites entre as mesmas ficam pouco claros.

No que se refere às atitudes básicas, observamos a presença de oposição com traços de desprezo, D-E:1 “Era uma vez, como começa toda estória, não tem muito o que dizer...” e a insegurança que aparece com necessidades de proteção e ajuda, D-E:5 "Quando você nasce destinado a uma finalidade, mesmo que tente mudar, correr por outros caminhos, será muito difícil, você encontrará muitos obstáculos no seu caminho...”.

Os sentimentos referem-se àqueles derivados do conflito, que surgem da luta entre o instinto de morte e o instinto de vida. As necessidades são de suprir faltas básicas com desejo de proteção, de compreensão e de ser cuidado. 
Os impulsos são amorosos, D-E:5 “...por outro lado pensará nas pessoas que ama...” e a ansiedade é do tipo depressiva.

Como mecanismos de defesa, destacam-se a projeção das dificuldades em lidar com as situações e frustrações e a racionalização, onde Marcos procura explicar os desenhos descrevendo-os para evitar contato emocional.

\section{Reflexão sobre o caso}

Marcos busca testar os limites, o que indica uma não introjeção deste, provavelmente em função da figura paterna ausente ou deficiente. Seu avô talvez não tenha conseguido ser o precipitador do limite externo e Marcos busca a integração de sua agressividade. A infração surge como um reflexo deste teste e uma tentativa de elaborar seus conflitos.

Busca sanar a carência da mãe que o priva de sua convivência e amor, encaminhando-o para criminalidade.

O relacionamento com sua mãe e a imagem que ele criou dela o levaram-no a acreditar que vínculos afetivos são frágeis e pouco confiáveis e há o risco de sofrimento muito grande, pois, quando se apega afetivamente a um objeto, logo recua.

A volta para a casa dos avós mostra um aspecto positivo através da busca de um ambiente estável. Assim como surgem aspectos saudáveis em suas produções.

Ele precisa ser ajudado a elaborar suas faltas primitivas através de vínculos seguros e confiáveis. Percebemos que há a possibilidade de receber esta ajuda, pois ele entra em contato com sua subjetividade e há um espaço potencial preservado. 
Com o estabelecimento de um vínculo seguro, ele começa a manifestar partes mais saudáveis, vai sendo tomado por uma ansiedade de tipo depressiva e parece se envolver em um processo de elaboração de seu conteúdo interno e na expressão de seus sentimentos; portanto, há espaço subjetivo para elaboração dos seus conflitos, talvez com bom prognóstico. 


\subsection{Pedro}

Pedro é encaminhado ao atendimento psicológico por recomendação de sua educadora, porque apresentou dificuldade de aprendizagem. Ele abandonou os estudos, quando cursava a quinta série do ensino fundamental por considerar que não conseguia aprender.

Ele é sempre introvertido e reservado, porém com um comportamento excessivamente educado, fala pausadamente como se estivesse contando uma história sobre alguém que lhe é estranho, não se aprofunda em suas experiências pessoais, emoções ou sentimentos.

Tem dezesseis anos e teve sua primeira apreensão por roubo, onde recebeu medida sócio educativa de Liberdade assistida após passagem pela FEBEM e pela VEIJ. Comparece ao primeiro atendimento acompanhado pelo pai, que demonstra participar de forma interessada na educação do filho.

O adolescente é proveniente de uma família constituída por seus pais, que sempre conviveram juntos, e por seus irmãos : uma jovem de dezoito anos e um rapaz de dezenove , que também residem com a família.

O pai relata que Pedro teve um desenvolvimento normal e seu comportamento nunca teve grandes alterações, muitas vezes contesta os conselhos dos pais, mas sem agressividade.

Considera-o bom filho, acredita que ele não teve culpa pelo ato infracional. Seu único problema é a dificuldade em aprender. 
A manutenção da família provém do trabalho do pai como marceneiro, sua mãe, que é doméstica, e seu irmão, que é instrutor de futebol. Vivem humildemente, mas sem privações, embora Pedro almeje por melhores condições financeiras para sua família .

Pedro nega o uso de drogas ou envolvimento em atos ilícitos, afirma passar o dia em atividades com os amigos no bairro ou desenhando, o que lhe dá muito prazer, sonha em ser desenhista, pois é "bom nisso".

Além da paixão pelo desenho, Pedro conta que já trabalhou em um circo, era palhaço, fala com carinho deste período e lamenta ter tido que o deixar depois que o circo mudou-se para longe. Pretende voltar a realizar essa atividade, já que lhe dá prazer ver as crianças se divertindo.

Quanto ao ato infracional, relata que saiu com um amigo e não sabia que este tinha a intenção de roubar; quando percebeu, não havia mais como sair da situação, acredita que foi "injustiçado", pois não teve culpa.

Afirma não querer voltar a praticá-los, mas não garante, pois algumas coisas podem fugir-lhe do controle. Vê o roubo como possível solução para necessidades.

Ele fez diversas críticas ao sistema judiciário, à FEBEM, às atividades dos policiais e às pessoas em geral, todas essas críticas estão voltadas para uma tentativa de isentar-se da responsabilidade de seus atos.

Demonstra grande dificuldade em se posicionar, ao falar de seus sentimentos, e em expressar afeto, apesar de falar de sua vida detalhadamente.

Em seu discurso percebemos que consegue fazer distinção entre o que considera certo e errado e tem uma tendência a avaliar ou qualificar as situações e as pessoas, levando em consideração, para tanto, valores externos. Sente-se impotente diante das situações; por isso, não se responsabiliza por elas. 
Sempre mantendo uma postura cordial, colaborativa e social, mostra uma preocupação em realizar tudo corretamente e dar respostas corretas, passa muito tempo em cada desenho atendo-se a cada detalhe demoradamente, dando explicações para todas as suas atitudes.

Após três atendimentos, ele conseguiu se inserir em núcleo escolar e começou a trabalhar em tempo integral, auxiliando um vizinho a vender frutas em um veículo pelas ruas. Desta forma, justificou que não há mais tempo para comparecer aos atendimentos.

\section{Questionário Desiderativo}

1+ Papagaio: para poder falar

2+ Rosa: é bonita, quando as pessoas vêem, se encantam

3+ Não sei , não quero ser nada inanimado. ( não conseguiu responder mesmo após indução)

1- Cachorro: se cair na mão de uma pessoa que não soubesse cuidar ia ficar apanhando

2- Maçã: todo mundo gosta de mordê-la

3- ------ ( não conseguiu responder mesmo após indução)

\section{Análise do Questionário Desiderativo}

No Questionário Desiderativo de Pedro, percebemos a falha na Primeira

Dissociação Instrumental, que representa uma inadequação da repressão básica, com a 
dificuldade de uso do mecanismo de simbolização, sendo que esse bloqueio ocorre mesmo após indução.

Através da análise global do teste, percebemos que este pode estar ligado dinamicamente ao reino omitido, pois o reino inanimado, caracterizado por objetos sem ação e passivos, leva-nos a pensar em um repúdio destes aspectos.

Ocorre, também, uma falha na Segunda Dissociação, onde ele utiliza o cachorro na primeira Catexia Negativa, o que não é convencionalmente esperado. isso ocorre, também, na escolha da maçã na segunda Catexia Negativa. Assim, pode haver certa dificuldade em discriminar aspectos valorizados ou rejeitados pelo Ego.

Percebemos, pelas racionalizações, que as escolhas foram feitas, não pela qualidade do objeto em si , mas por uma atitude externa em relação a ele, o que nos faz pensar que para ele objetos bons podem receber uma resposta negativa do mundo, através de um julgamento.

A elaboração das respostas parte de pressupostos subjetivos, mas não chegam a ser incoerentes, então, esta dificuldade da racionalização está relacionada a conteúdos afetivos. Percebemos, também, a presença da ansiedade persecutória nas respostas 1- e 2- .

A escolha dos símbolos está relacionada à utilidade destes e a uma questão de justiça, e há uma exclusão da afetividade nas respostas. Esse modo de responder ao teste está relacionado à presença de traços obsessivos de funcionamento psíquico.

A resposta 1+ está relacionada a um desejo latente de falar e ser ouvido e na resposta 1- surge a preocupação em ser cuidado e o temor de que isso não irá ocorrer. 


\section{Desenho - Estória:}

D - E: 1

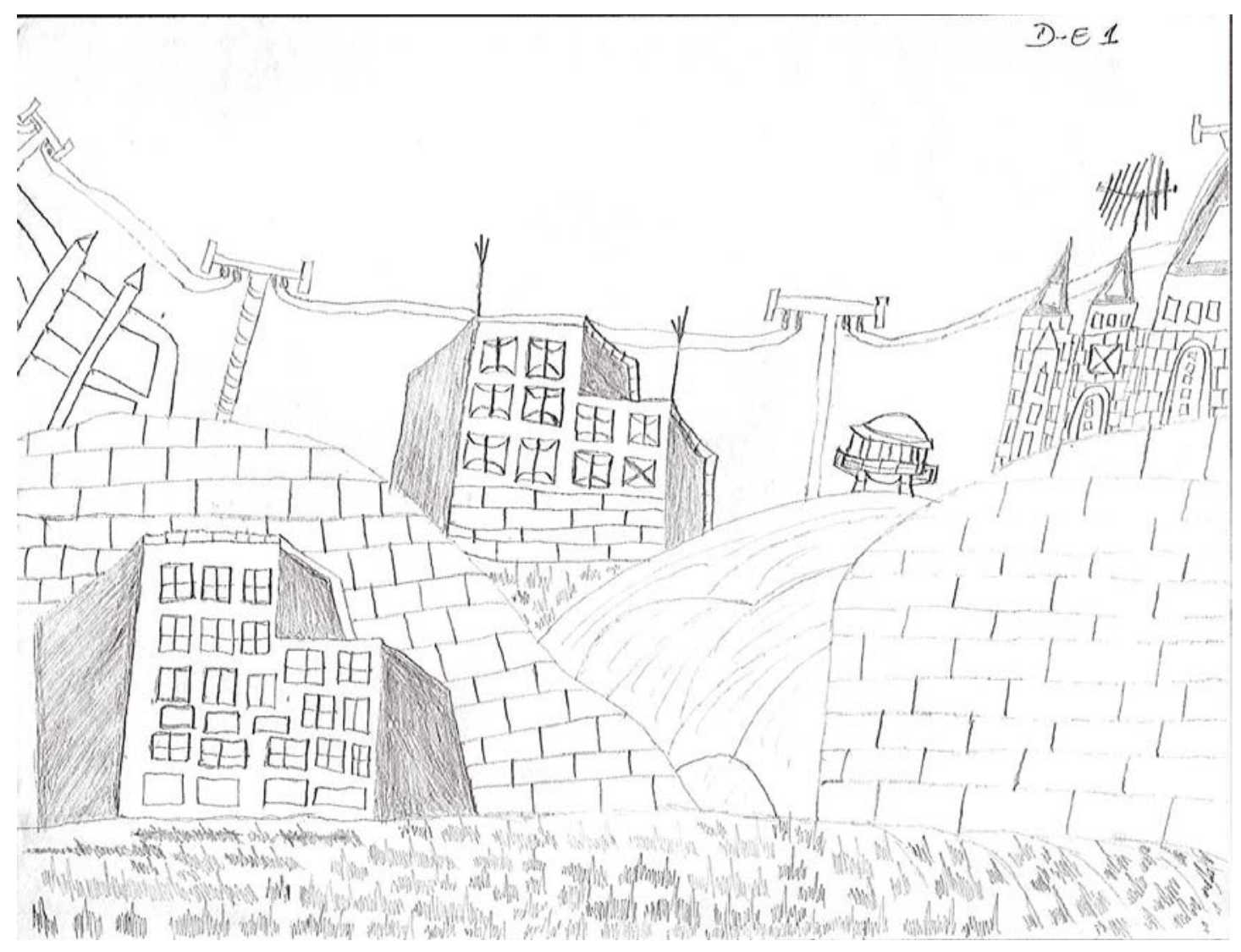

Título: UAI e UIP 8

Muita tristeza, muita revolta. A UIP 8 é melhor, dá pra conversar, se divertir.

Essa é minha história, história sem fim. Coloquei a igreja que é pra não esquecer os caras crentes e católicos que vão lá. 
Tem a fazendinha do Morro da USP, aqui atrás, a fazendinha dos ricos que têm medo de nós.

D - E: 2

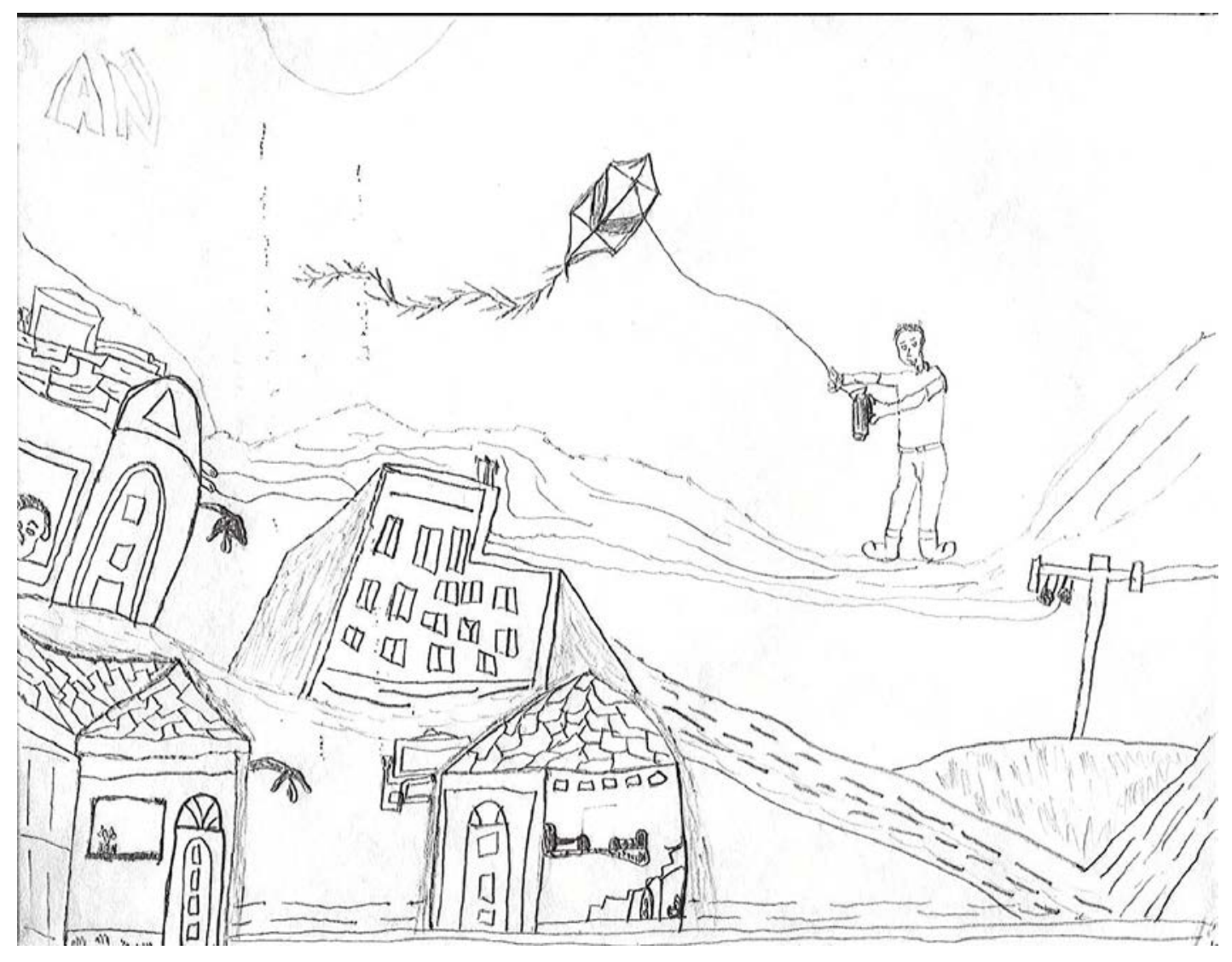

Título: A Vilinha da Paz

Os meninos gostam de se divertir, jogar pipa no terreno, jogar bola na quadra. Só isso. 


\section{Análise dos Desenhos - Estórias}

Os desenhos de Pedro são bem detalhados e revelam uma identificação com as situações e ambientes em que vive. Deste modo, o sujeito expressa suas vivências e cotidiano , bem como, conflito que sente entre aquilo que é “Bom” e o que é "Mau”.

Na unidade 1, ele retrata a revolta que sente em relação ao sistema da FEBEM e em relação ao preconceito sentido pelas outras classes sociais.

Na unidade 2, parece estar relatando seu desejo de continuar em uma condição infantil, na "Vilinha da Paz", fato que também pode ser percebido na entrevista.

Como atitude básica, podemos destacar a insegurança, com necessidades de proteção, abrigo e ajuda "Muita tristeza, muita revolta... essa é minha história, história sem fim...". Outras figuras são vistas como positivas, "os meninos gostam de se divertir, jogar pipa no terreno, jogar bola na quadra”.

Em relação aos sentimentos expressos, observamos os derivados do conflito, “Muita tristeza, muita revolta... esta é minha história, história sem fim” e os sentimentos derivados do instinto de vida, "Os meninos gostam de se divertir, jogar pipa no terreno, jogar bola na quadra”.

Do mesmo modo, destacam-se as tendências construtivas. As ansiedades são depressivas. 
Os mecanismos de defesa utilizados são a projeção de aspectos do mundo interno e do mundo externo e dos desejos. 


\section{Discussão com base nos dados obtidos}

Pedro vivencia o processo de busca pelo seu verdadeiro eu, mas ele busca a manutenção da infância, pois há um conflito ligado à responsabilidade em elaborar o amadurecimento que requer a possibilidade de manejar sua agressividade. $\mathrm{O}$ ato infracional apresenta-se como uma manifestação da dificuldade de introjeção dos limites e em um movimento de busca por essa integração.

Alguns dados aparecem nos procedimentos realizados que indicam a presença de características típicas da adolescência, como a dificuldade em discriminar realidade e fantasia, criticas e questionamentos, a presença da ansiedade depressiva, talvez relacionada aos lutos vivenciados neste momento, e a dificuldade em estabelecer valores próprios.

Faz parte do processo de 'adolescer' testar os limites das figuras parentais e se faz necessário que estes possam sobreviver e responder adequadamente a estes testes.

A experiência da infração marcou-lhe como algo injusto, um rechaçamento que ele não entende e que tem a necessidade de expressar na tentativa saudável de elaboração.

Existe um espaço potencial disponível para a elaboração, ele precisa de ajuda neste processo de descobrir-se e procurar o que lhe faz sentido, devendo ser proporcionado o fortalecimento egóico. Globalmente parece estar lidando também com o que é próprio do processo de adolescer e necessitando auxílio na elaboração dessas vivências.

\subsection{André}


André veio ao atendimento por iniciativa sua e estímulo de sua educadora, para que amadurecesse seus projetos e avaliasse seus valores. Possui dezessete anos e é bem desenvolvido fisicamente para sua idade, diferenciando-se dos outros adolescentes por seu porte físico. Foi apreendido por roubo e iniciou cumprimento de Liberdade Assistida em dezembro de 2002.

Desde o início, mostrou um comportamento muito extrovertido, parecendo sempre estar com bom humor, falava muito, durante o atendimento, sobre assuntos diversos.

Fazia críticas ao sistema econômico, às desigualdades sociais e aos preconceitos, mantinha um comportamento agitado e diversas vezes dramatizava seus relatos com gestos e movimentos corporais, fazia piadas sobre tudo, mesmo falando de situações tristes de sua vida e, quando isso foi apontado a ele, disse que "prefere levar a vida na brincadeira para sofrer menos".

Possui intensa necessidade de troca com o psicólogo. Sempre que se posiciona, pede também opinião do entrevistador, aproxima-se fisicamente e conta tudo com muito interesse, porém sente-se pouco à vontade para falar de si, de sua família e das situações vivenciadas com a morte do pai, desconcerta-se e procura desviar-se do assunto sutilmente passando a tecer críticas intelectualizadas, fazendo com que fique emocionalmente distanciado.

Conta-nos que mora com a mãe e dois irmãos, um com dezoito anos e outro com vinte anos de idade. Refere-se a eles de forma afetiva e nos diz que o relacionamento é muito bom, sente-se amparado.

O pai foi assassinado quando tinha cinco anos; todos estavam em casa dormindo, só a mãe presenciou tudo. 
André não consegue explicar os motivos, acredita que o pai não estava envolvido em "coisas erradas", ele era da polícia e "não gostava de bandido". Ele se questiona constantemente sobre os motivos, buscando justificativas que isentem seu pai de responsabilidades.

Acredita que se estivesse vivo sua vida seria bem diferente, pois não se envolveria em delitos. Ele e um de seus irmãos tiveram uma discussão, e este afirmou que se o pai estivesse vivo teria vergonha de André.

Após o assassinato do pai, a família teve de mudar de estado, passaram por muitas privações para reconstruírem suas vidas; apesar de tudo, afirma que não lhe faltou nada, acentua sempre os méritos da mãe em conduzir adequadamente a família. Ela foi chamada diversas vezes ao atendimento, mas não compareceu, só vindo a ter contato quando a educadora que o acompanhava nas visitas domiciliares, assim, não foi possível uma melhor análise da relação entre eles.

Quanto ao delito, André acha que teve cabeça fraca, por isso infracionou, diz que aconteceu "de repente", lhe convidaram para um roubo de veículo e ele não pensou em alguma conseqüência.

André articula bem suas idéias, possui crítica aguçada, reflete sobre questões de ordem social, apontando falhas relacionadas à polícia, ao governo, ao sistema judiciário e à FEBEM, críticas estas bem fundamentadas com um cunho realístico.

Interrompeu os estudos na sétima série do ensino fundamental, porém procura vaga no curso de aceleração, afirma querer terminar o ensino médio.

Procura canalizar suas energias praticando esportes em entidades da região, boxe, jiu jitsu e capoeira. Tem um projeto: treinando capoeira quer se tornar mestre e ter sua própria academia, coloca muitas expectativas neste, achando que desta forma viverá 
honestamente, deseja ser um grande professor e ensinar seus alunos a fazer o bem $e^{\text {" quem }}$ sabe adolescentes infratores para saírem desta vida".

André continuou o processo psicoterapêutico até o encerramento de sua medida, continuou com as atividades esportivas e inserido em núcleo escolar.

\section{Questionário Desiderativo}

1+ Deixa eu ver , pássaro podem atirar uma pedra , peixe podem pescar, já sei quero ser gato para ficar deitado no sofá e o dono fazendo carinho em mim.

2+ Não queria ser vegetal, pra não se comido, ah! um Cacto, quero ver alguém me comer agora.

3+ Copo não, você ia lá tomava água e depois me deixava num canto. quero ser um Diamante caríssimo, para ficar no museu parado e todo mundo admirando, mas alguém podia me roubar.

1-Lesma, muito parada pra mim, aquela coisa nojenta, fica rastejando

2-Alface, não quero ser comido na salada

3- não quero ser nada descartável , como copo plástico , caneta folha, porque não quero ser jogado fora.

\section{Análise do Questionário Desiderativo}


No Questionário Desiderativo, percebemos que ele é capaz de utilizar-se da repressão básica e fornecer respostas símbolo, contudo, é marcante o fracasso na segunda dissociação .

Percebemos esse fracasso pois ele responde as catexias positivas com símbolos rejeitados, demonstrando um fracasso na separação do que é valorizado ou rejeitado pelo Ego e dos aspectos bons e maus dos objetos e um conflito nesta escolha com a presença de um modo de funcionamento ambivalente. (respostas 2+ e3+)

O fracasso na identificação projetiva se faz notar através da perda da distância emocional, com a racionalização emitida em primeira pessoa e na eleição de mais de um símbolo em uma mesma catexia. (respostas 1+, 2+, 3+ e 3-).

A escolha de diversos símbolos nos faz pensar que para ele nenhum objeto é suficientemente bom para satisfazê-lo e que por outro lado o teste mobiliza - o muito, a ponto de haver um forte incremento da ansiedade.

Ansiedade esta que se mostra do tipo persecutória não apenas por este movimento de escolher vários símbolos, como também pela qualidade destes, (resposta 2+). Ela se faz notar, também, no forte temor de que o mundo o invada, o descarte, o "jogue fora. Há um temor do desprezo e da rejeição.( respostas 2+, 3+ ,2- e 3-). Assim como , em quase todas as catexias surge um risco de ataque. (respostas $1+, 2+, 3+, 2-$ e 3-).

Essas características, bem como as rejeições de símbolos impotentes e expostos ao ataque, objetos usados e evacuados, com impulsos orais de incorporação sádica e as respostas de diamante $3+$, e cacto 2+, representativas de uma evitação de contato afetivo(respostas 3+ e 2+), apontam para a presença de traços esquizóides de funcionamento psíquico .] 


\section{Desenho Estória:}

André: Pode fazer uma linha?

Psicóloga: Sim

A: Seria melhor com régua, a Sra. não dá régua?

P: Não é preciso

A: Me mostra a folha vazia. Sabe o que é isso? A vaca comendo capim no pasto, não viu o capim é porque a vaca já comeu. Não ... é a Monalisa mas só as pessoas inteligentes vêem. 


\section{D-E 1}

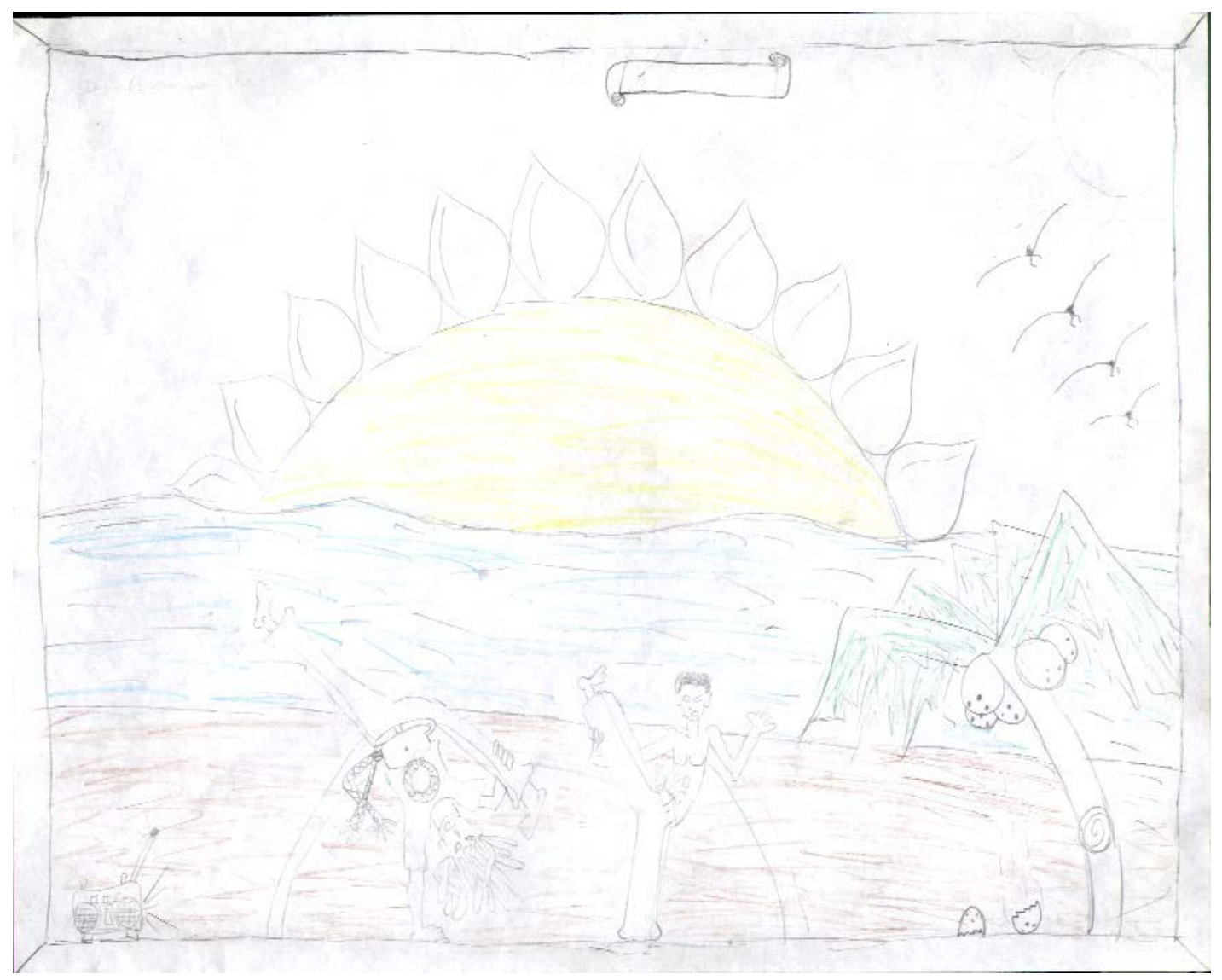

Título: Lembrança de Porto Seguro

Minha mãe sempre disse pra eu entrar em um curso de desenho, eu não sabia para que iria usar, eu sempre ficava desenhando em casa.

Parece um coqueiro? pelo menos tem um coco.

Estou sujando muito a mesa , depois eu limpo. (começa a cantar) não consigo desenhar com alguém me olhando, porque eu gosto de fazer as coisas concentrado . Alguém me observando assim fica esquisito.

André: A Sra. me viu de rastafari? Ah! não, eu não tinha começado aqui ainda. Até que eu não sou tão mal assim, desenhando. 
Minha mãe queria que eu tocasse algum instrumento, mas o único instrumento que eu sei tocar tem uma corda só.

Tá vendo como não dá pra fazer nada obrigado?

Psicóloga : Por que você está dizendo isso ?

André: Não tem nada a ver com o que eu estou fazendo agora. Tá vendo como é ruim falar com psicóloga .A Sra. tem hora para ir embora?

Psicóloga: Por quê?

André : Porque eu estou demorando muito para desenhar.

Psicóloga : Não tem problema.

André : Olha, é na Bahia isto aqui , vou para lá quando eu me formar em capoeira, lá tem a tradição da capoeira que aqui está muito distorcida. Até quando vai o inverno? A Sra. gosta de frio?

Psicóloga: Por que você pergunta?

André: eu não gosto porque tem que ficar com muita roupa, prefiro ficar mais à vontade.

Esse aqui podia ser meu irmão, mas ele parou a capoeira, agora está fazendo boxe, ele fez uma escolha, está se dando bem.

Desenhei um rádio, porque está muito cedo lá na Bahia e eu não ia levar todos os meus alunos para treinar, então, levei só uma pessoa comigo para treinar os movimentos e depois ensinar aos alunos. Esse é um aluno meu; quando eu me formar, vou levar comigo para passar um dia lá.

Esse desenho simboliza o meu objetivo que é treinar firme, conseguir me formar, ter meus alunos e ensinar para outros estados e países: Bahia, Rio de Janeiro, posso fazer como o João Grande e ir para os Estados Unidos. 
E esse é eu, vou por meu canecalon de novo.

D - E: 2

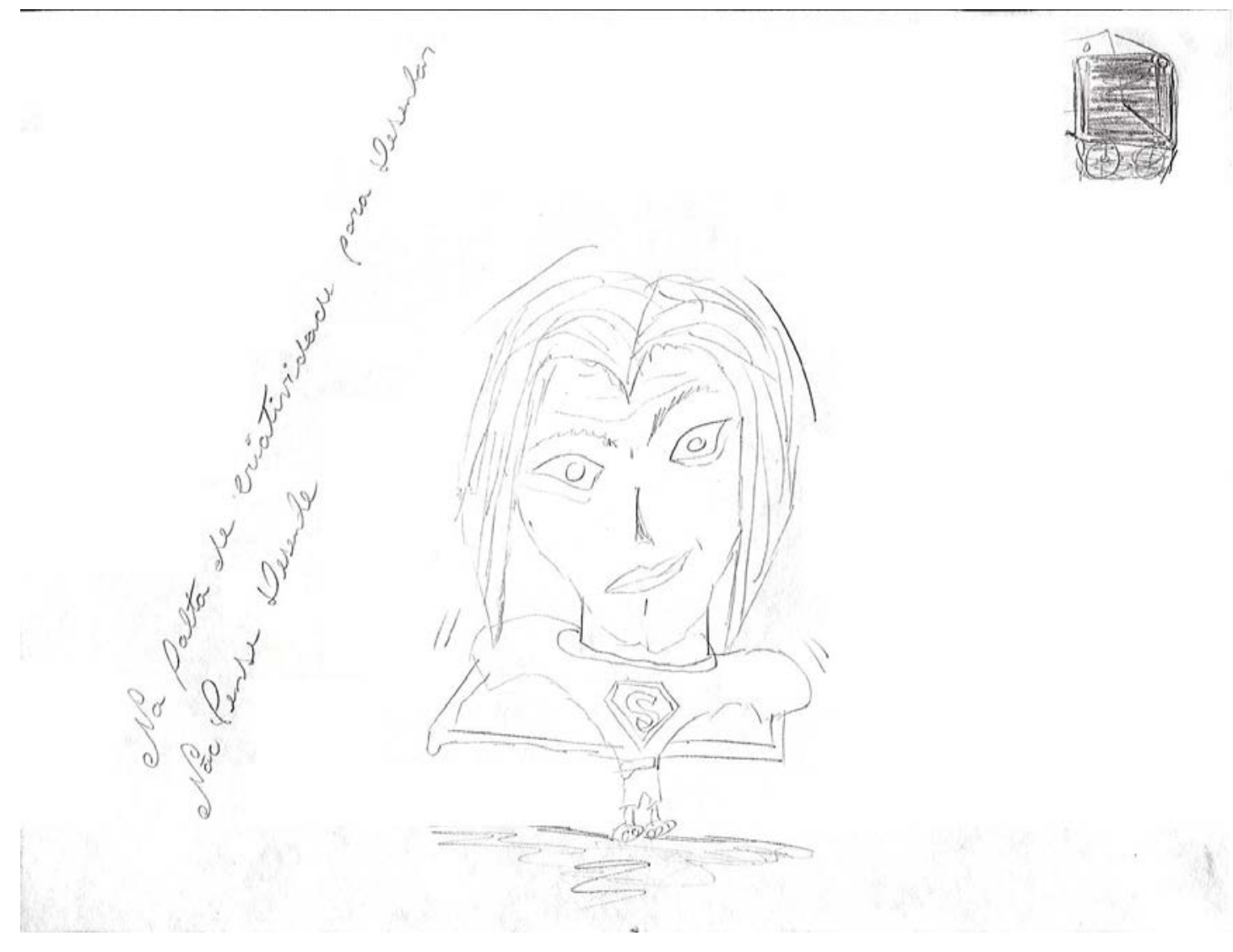

Título: Na Falta de Criatividade para Desenhar, Não Pense: Desenhe.

André: A Sra. já tentou fazer um risco e juntar para formar um desenho, é uma terapia boa para a Sra. que é psicóloga. A Sra. usa óculos, que coincidência, eu também. Vou te mostrar o que foi que passou pela minha cabeça pra desenhar, só que eu vou desenhar pequeno que eu acho que a Sra. não vai gostar ( desenha um quadrado negro).

Esse desenho é um quadro negro, foi a primeira coisa que eu pensei, com um quadro negro pode se fazer muitas coisas com ele, como exemplo: um dado, um caminhão, eu estou mal 
para desenhar ( começa a rabiscar) é só. Vamos trocar de folha ? Só para não dizer que eu não desenhei nada ( faz a produção)

A Estória é assim : A Sra. propôs que eu fizesse um desenho, de imediato não veio nada em mente.

Eu fiz um desenho simbolizando uma caricatura da supergirl que está meio raquítica , não está se alimentando bem. ela está pensando assim: eu sou a supergirl e tem um adolescente em perigo, ele está tentando fazer um desenho e não consegue, o que eu farei para ajudá-lo? Com minha telepatia super biônica vou dar uma forcinha para meu amigo para fazer um desenho sobre... continua a semana que vem. 
D - E: 3

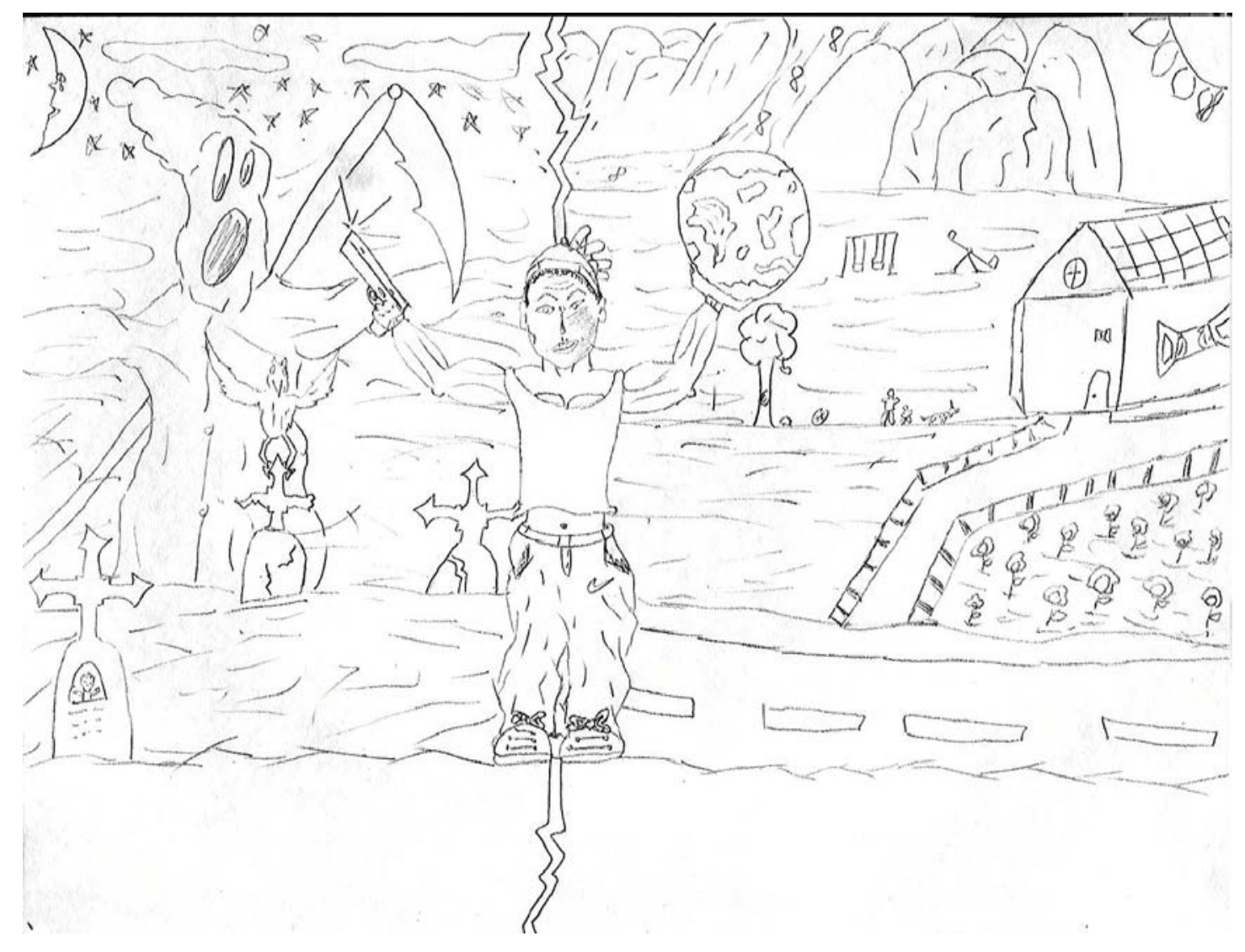

Título: Na Vida Existe Dois Caminhos..."Faça Sua Escolha”

Na vida existe dois caminhos. Você pode tanto escolher o caminho bom quanto o ruim, pois a escolha está em suas mãos. Sua mão direita pode estar o mundo e você pode modificar o mundo e na outra mão está o crime, as drogas, as armas e a violência. Acredite em si mesmo que você pode mudar o seu amanhã.

Ter um dia feliz, fazendo os outros felizes. 


\section{Análise dos Desenhos - Estória}

Nas unidades de produção deste sujeito, observa-se que ele tem uma atitude de provocação , projetando sentimentos agressivos na relação .

O adolescente chega a relatar que é "ruim falar com psicóloga”. Na Segunda unidade de produção, parece fazer uma identificação com uma figura fraca que não teria condições de auxiliar um "adolescente em perigo".

Nos desenhos aparecem traços de repressão e resistência, que confirmam que a relação o perturba. "Estou sujando muito a mesa, depois eu limpo".

Na produção 2 parece se identificar com o personagem adolescente da estória, que precisa ser ajudado pela figura desenhada "a supergirl que não está se alimentando bem, está meio raquítica”.

No que se refere às atitudes básicas, aparecem no D-E as necessidades de aceitação e insegurança, já que ele parece estar constantemente preocupado com o que pensamos sobre o que ele está fazendo.

Esses dados nos levam a crer que suas relações são permeadas por uma forte ansiedade persecutória. No D-E 2, apesar de a figura projetada da psicóloga ser descrita como raquítica, possui grandes olhos que parecem o estar vigiando.

A análise global leva-nos a supor que ele vive seu ambiente como desprotetor e agressivo e como se sente impotente para lidar com tal fato. Do mesmo modo, na entrevista, os conflitos familiares parecem ser vividos com sentimento de impotência.

As elaborações confirmam as hipóteses, levantadas na entrevista, do uso de recursos, como: intelectualização e racionalização para lidar com as situações ansiogênicas. 
Enquanto no D-E:1 outras figuras são vistas como positivas (o irmão e os alunos), no D-E2 a figuras são vistas como negativas (a supergirl raquítica). Os sentimentos nas duas unidades de produção referem-se aos derivados do conflito, "é ruim falar com psicóloga”.

Por outro lado, as produções de André parecem estar refletindo seus próprios desejos de progresso e desenvolvimento, já que ele fala nisso de forma recorrente.

Aparecem tendências construtivas ligadas à necessidade de autonomia e crescimento, “Acredite em si mesmo que você pode mudar o seu amanhã. Ter um dia feliz, fazendo os outros felizes” e necessidades de suprir faltas básicas, desenha uma supergirl, que é “raquítica, que não está se alimentando bem” e que tem um adolescente pra ajudar.

André parece ter dificuldade em entrar em contato com tal necessidade, já que quando isso acontece ele usa a repressão e diz querer parar de desenhar para continuar na próxima semana. Os impulsos são os amorosos e as ansiedades que prevalecem são as depressivas.

Como mecanismos de defesa, destacam-se a repressão, a projeção e racionalização. 


\section{Reflexões sobre o Caso}

André comparece à psicoterapia por iniciativa própria, sua esperança está preservada e isso é positivo.

Tem uma excessiva verbalização, um discurso elaborado, mecanismos de racionalização, intelectualização e comportamento agitado, o que indica um desenvolvimento prematuro do psiquismo como forma de defesa para as vivências emocionais traumáticas.

Possui uma necessidade de troca e provocações com o psicólogo, mas ao mesmo tempo há tentativa de aproximação emocional, ele testa a sobrevivência do vínculo, na capacidade do outro em superar suas provocações, ele necessita de que alguém sobreviva, busca por preenchimento das faltas básicas vivenciadas.

Seu pai se foi deixando um enigma, sentimentos ambivalentes em relação a ele que tenta retomar a tragédia familiar.

Na entrevista mantém certa organização Egóica , utilizando-se adequadamente das defesas, porém nas produções surgem seus aspectos dicotomizados e persecutórios.

A excessiva perda de distância emocional que surge em suas produções indicam uma dificuldade em lidar com situações reais. O conflito entre o que é bom ou mau é visto de forma dicotomizada e se impõe como uma escolha. Toda a produção de André mostra um mundo interno povoado por objetos com aspectos bons e maus não integrados.

Existe um espaço potencial preservado e pode ser utilizado no sentido de que há esperança e crença em sua capacidade e potencialidade. Possui um movimento de recuperação voltado para o desejo de fazer o bem a outras pessoas até mesmo adolescente infratores, reconhecendo assim sua própria necessidade de receber ajuda. 
Busca por crescimento e desenvolvimento, há uma crença em si e em sua capacidade de alcançar suas metas. Assim, de alguma forma, surge algo positivo do suporte ambiental e terapêutico, pois André organiza sua vida de forma saudável.

Ele necessita de acompanhamento psicoterapêutico no sentido de continuar elaborando seus conflitos e buscando a integração destes aspectos dissociados dos objetos. 


\section{5 - DISCUSSÃO DOS RESULTADOS}

Buscamos utilizar as entrevistas e procedimentos de forma complementar, elucidando a dinâmica inconsciente, os conflitos, mecanismos de defesa, estados emocionais, ansiedades predominantes, relações de objeto e, através destes, os aspectos sadios e patológicos da personalidade de cada adolescente.

Através dos aspectos mais patológicos da personalidade, delimitamos um possível prognóstico, inferindo sobre as estratégias de ação mais indicadas. Os aspectos sadios evidenciados, são valorizados, assim, como o vislumbre de potencialidades a serem desenvolvidas.

Realizado sob essa perspectiva, o trabalho psicodiagnóstico contribui para a compreensão globalizada do indivíduo, permitindo sua inclusão na sociedade e não a sua estigmatização, que leva à exclusão.

O Psicodiagnóstico clínico de natureza compreensiva possui a característica de manter um olhar globalizado sobre as informações obtidas com cada um dos instrumentos e 
técnicas empregadas, pois cada um deles nos traz, pelas suas características, uma amplitude específica de informações.

As Produções dos Desenhos-Estórias possuem traços mais saudáveis do que as do Desiderativo, inferimos, assim, que este último representa um ataque mais incisivo ao Ego, enquanto o Desenho- Estória oferece a possibilidade de elaboração dos conteúdos e reestruturação da personalidade diante da tarefa.

Os dois procedimentos enriquecem os dados colhidos na entrevista clínica, trazendo dados que não surgiram nesta ou explicando-os e, em todos os casos, eles se confirmam.

Nos Procedimentos de Desenhos-Estórias, alguns traços ficaram evidenciados como o uso predominante do mecanismo de projeção no enfrentamento da tarefa. Os Desejos e Necessidades predominantes são relacionados a faltas básicas, com a expectativa de proteção, abrigo e ajuda. O que corrobora a questões da falha ambiental e da tendência anti-social como resultado desta. As figuras surgem tanto com qualidades negativas, quanto positivas e, em alguns casos, há a ausência destas. Há uma predominância dos impulsos amorosos e tendência construtivas, bem como de ansiedades depressivas, o que é um fator positivo. De modo que podemos considerar que há um espaço potencial preservado que poder ser uma via de acesso à transformação.

Quanto a aspectos formais, percebemos que, em sua maioria, os desenhos apresentam-se de forma regredida em relação à idade, com pouco uso de cor e as Estórias possuem , em sua maioria, pouca elaboração.

No Questionário Desiderativo, percebemos que, em geral, há possibilidade de discriminar fantasia e realidade, fazendo-se uso do mecanismo de simbolização. É marcante, porém, algum nível de impossibilidade em discriminar aspectos rejeitados e valorizados pelo Ego, bem como, debilidade no mecanismo de identificação projetiva e 
racionalização. O tipo de relação objetal , em todos os casos, é narcísica e podemos considerar que as relações se estabelecem desta forma, como uma organização defensiva, resultado de um self patológco, constituído para defender-se das diversas evasões ao Ego que ocorreram ao longo do desenvolvimento psíquico.

Podemos inferir que a presença predominante da ansiedade persecutória ao longo das produções é um reflexo da não elaboração da posição depressiva. Assim, há uma impossibilidade de integração dos aspectos bons e maus dos objetos, como vemos em André e Paulo, e do próprio self, como elucidado no caso Lucas.

Não havendo a compreensão de que estes aspectos fazem parte do mesmo objeto, estabelece-se um mundo interno repleto de objetos cindidos, esta característica é projetada no mundo e eles passam a vivê-lo como algo cindido, não havendo alternativas, vivenciam o conflito da escolha e em alguns casos não se permitem entrar em contato com os próprios aspectos maus.

Não permitindo entrar em contato não há a possibilidade de elaboração dos conflitos e integração destes aspectos.

Não há, porém, como inferir a predominância de algum traço Psicopatológico de funcionamento Psíquico nos casos, pois encontramos traços depressivos, histéricos e esquizóides, confirmando que a tendência anti-social pode surgir em qualquer quadro ou estrutura de personalidade.

Nas histórias clínicas, percebemos que todos os adolescentes são provenientes de uma classe social desfavorecida e possuem vivências de dificuldades financeiras em diferentes níveis. Tal característica pode ser compreensível dada a localização, em região de periferia, da instituição que sediou a pesquisa. Mas, através dos discursos, em sua maioria, percebemos uma adequada percepção desse desfavorecimento, bem como a crítica 
deste e desejo de posse. Em alguns, percebemos esse desejo de posse , diretamente relacionado com à possibilidade de felicidade, expectativa futura e adequação da vida, como é o caso de Lucas e Mateus.

Nestes 8 casos não é possível estabelecer uma relação direta entre estas vivências de privações e dificuldades financeiras com o fato de terem cometido um ato infracional , porém as pesquisas citadas neste trabalho apontam para a importância de todos os fatores atrelados a essa situação, como : convivência com violências de todos os níveis, situações de injustiça e criminalidade.

Mostrando o quão pouco acolhedor se apresenta o cenário social que se desenha hoje. A nação relega seus filhos à privação; à rejeição e impossibilita a inserção adequada dos jovens no seio da sociedade.

Não é possível desconsiderar que as mazelas da sociedade não se reflitam nas condições da família e desenvolvimento dos jovens, bem como tragam marcas e modifiquem suas vivências.

Em uma sociedade violenta, capitalista, que oferece modelos identificatórios inadequados, que valorizam as condutas desonestas e violentas, e, preconizando a posse material como acesso fácil à felicidade, os jovens são obrigados a inserir-se neste padrão, e na impossibilidade, são estigmatizados e excluídos. Sabem o que podem ter, mas não têm acesso aos recursos disponíveis a outros jovens.

Percebemos como comum, nos casos estudados, a vivência de algum nível de desestruturação familiar, excetuando-se o caso de Pedro.

Sete deles possuem pais biológicos separados, sendo que parte destes convive com padrastos que, na maioria das vezes, não é uma figura de identificação. 
Em cinco dos casos, a figura paterna possui características manifestamente vistas como negativas, sendo comum o envolvimento delituoso, o alcoolismo, drogadição e atitudes violentas por parte deles.

Excetuam-se Pedro, cujo o pai não se caracteriza dessa forma, André, cujo pai faleceu deixando-lhe uma imagem ambígua e João em que essa figura, praticamente, inexiste.

A maioria dos jovens expressa sentimentos negativos relacionados ao pai que, na maioria das vezes, abandonou a eles e a família, até mesmo com atitudes de rejeição .

Desta forma, inferimos a importância do papel da figura paterna no desenvolvimento psíquico, bem como de uma introjeção adequada dessa relação e relacionamos a patologia deste relacionamento com a problemática da tendência anti-social. Por outro lado, devemos lembrar que o pai facilita a entrada da mãe em um estado que possibilitará que ela forneça os cuidados adequados ao bebê.

As vivências de abandono e rejeição são comuns, principalmente em relação à figura paterna. No caso de João percebemos também o abandono da mãe e no caso de Marcos, Paulo e João a vivência de uma relação ambígua com essa figura.

Assim, evidenciamos que, em geral, eles vivem relações ambíguas e inseguras que os levam a vivências as mais diversas de privação e deprivação.

Alguns deles conviveram com situações de agressão e violência: André com o assassinato do pai, Marcos e Tiago com as agressões sofridas pela mãe, Tiago e Lucas com atitudes criminosas de membros da família.

Podemos afirmar, diante do histórico de vida desses adolescentes, que eles sofreram traumas psíquicos dos mais diversos níveis, relacionados a vivências de desestruturação familiar, perdas, abandono, rejeição e violência. 
A história clínica desses adolescentes confirma a importância das falhas, omissões ou privações da vida familiar, no desenvolvimento das tendências anti-sociais.

Inferimos que o ambiente que os recebeu ao nascimento não forneceu a estrutura necessária para o estabelecimento de relações seguras que favorecessem o saudável desenvolvimento psíquico desses jovens.

As gestações conturbadas e indesejadas ,assim como o não oferecimento de um suporte do companheiro à mãe, levam-nos a pensar na impossibilidade delas em se inserir em um estado de preocupação materna primária e consequentemente, não é oferecido aos seus bebês condições adequadas para um desenvolvimento psíquico sadio.

Famílias desestruturadas, com conflitos e agressões, não possibilitam o desenvolvimento de um ambiente facilitador propício ao desenvolvimento de um aparato psíquico que lhes dê condições para lidar com as adversidades da vida de forma positiva . Essas adversidades , porém, em razão das condições peculiares em que vivem , persistem.

Esses indivíduos encontram-se em um ciclo onde a situação ambiental não lhes permite o desenvolvimento psíquico adequado e este aparato psíquico não os instrumentaliza para lidar com as adversidades da vida

A adolescência representa uma magnificação dos conflitos primevos, onde ocorre um desequilíbrio das forças psíquicas e uma conduta patológica em algum nível, porém, esses adolescentes, já chegam pouco habilitados a gerir os conflitos próprios desta.

O padrão de enfrentamento das vicissitudes da vida assenta-se nas condições estabelecidas nos primeiros anos de vida.

As famílias mostram pouca possibilidade de dar o suporte ambiental necessário para gerir as dificuldades inerentes à adolescência. Quando chegam a este momento, encontram- 
se já com um arsenal de conflitos a serem geridos e não vivem o processo de aquisição da identidade adulta de forma salutar.

A violência na adolescência é resultante da desestruturação do psiquismo que data do desenvolvimento emocional primitivo, em decorrência de falhas do ambiente que o Ego não pôde suportar.

André é o único que faz referência à atividade profissional como possibilidade de realização pessoal e reestruturação de sua vida, tendo-a como principal fonte de expectativa. Pedro, Lucas e Marcos fazem referência a algum tipo de interesse profissional, porém, de forma pouco estruturada e amadurecida.

Não surge, também, o envolvimento com atividade que envolvam esportes, criatividade. Excetuando-se André e Pedro, na maioria das vezes, o lazer está relacionado ao envolvimento em brincadeiras de cunho infantil, como empinar pipa.

Assim, percebemos pouco investimento de libido em expectativas futuras, a inexistência de projetos e evidência do uso de recursos criativos.

Podemos pensar que a escassez de perspectivas e uso da criatividade está relacionada à não integração da agressividade, pois só a integração desta e dos aspectos bons e maus dos objetos em um ambiente adequado para tanto, permite o adequado desenvolvimento da capacidade de reparação. A não integração da agressividade e destes aspectos bloqueia as manifestações de amor e criatividade. A elaboração do impulso destrutivo se converte no desejo de reparar, de construir, de assumir responsabilidade pelo objeto.

Quanto à vivência infracional, em sua maioria, arrependem-se do ato, porém nestes casos o arrependimento está relacionado às conseqüências para si e para a família , não 
aparecendo em nenhum momento a preocupação com a vítima, apesar de em alguns casos existir uma percepção vaga de se ter feito mal a alguém.

Corroborando as hipóteses que esses adolescentes não desenvolveram a capacidade adequada de envolvimento que possibilitaria a preocupação com o objeto.

No caso de Marcos e Lucas não há , no discurso, a certeza de não voltar a infracionar, no caso de João há uma clara opção pela vida delinqüêncial e, em Paulo e Tiago, não há qualquer tipo de reflexão sobre o ato. Sendo este mais um indicativo de um desenvolvimento inadequado, pois não são capazes de assumir a responsabilidade por seus atos, sejam eles fracassos ou êxitos, não tomam posse de suas próprias vidas, não sentem que a vida valha a pena ser vivida.

Quanto à motivação que os levou a infracionar, apenas Lucas refere-se a questão das dificuldades financeiras e, em Pedro, vemos uma clara recusa da responsabilidade. Os outros associam de diferentes formas a inconseqüência da parte deles. Fica - nos claro, porém, a presença de motivos inconscientes em todos os casos.

As características citadas parecem-nos mais um indicativo da não integração da agressividade, dos aspectos dos objetos e dos aspectos da personalidade, pois, o ato infracional aparece como algo dissociado de sua vivência , não sabem por que o fazem , o que os leva a fazer, não conseguem entrar em contato com a questão, alguns com dificuldade até em falar do assunto, como se o fato não lhes pertencesse.

Enquanto temos em Paulo, Tiago e Mateus a ausência de uma reflexão crítica sobre a realidade, em André, Marcos, Pedro e Lucas vemos uma percepção mais ou menos aguçada das questões relacionadas à justiça e às desigualdades sociais ou a atitudes incorretas e desonestas. 
Os pares significativos, como irmãos e amigos, parecem ter alguma influência sobre a atitude destes, pois em alguns casos fazem referência á opinião destes ou percebemos clara identificação.

Essa questão também é citada nas pesquisas consultadas e lembramos que as vivências em grupo tomam relevância na adolescência , assim os pares significativos consagram-se como modelos identificatórios positivos ou negativos

No que tange à relação transferencial, percebemos que ela se caracteriza por uma atitude de distanciamento, clara no caso de Mateus ou marcada por algum traço de agressividade ou provocação da parte deles, como nos casos de Paulo, João e André. Eles já cobraram da família, da escola e da sociedade os limites e estabilidade ambiental de que necessitam, porém não lhes foram oferecidos, então ,cobram da relação terapêutica o que sob esta perspectiva evidencia-se como um aspecto positivo. Assim, é possível pensarmos que o trabalho terapêutico de qualquer natureza, com esses jovens, deve suportar as diversas provocações e testes que são feitos, pois estas representam a tentativa de integração da agressividade, o trabalho só se sustentará se oferecer a confiança nessa possibilidade.

Também não é possível falar em Psicopatia, pois vemos aspectos patológicos convivendo com aspectos sadios, bem como um movimento de elaboração dos conflitos que se refletia na fala, nas produções e na relação terapêutica.

Não podemos patologizar todos os achados concernentes ao funcionamento psíquico desses adolescentes, pois, a adolescência é um período onde se espera um desequilíbrio das forças do Id, Ego e Superego, com a predominância do uso de mecanismos psíquicos primitivos , onde há uma certa desestruturação e patologia. 
A maneira como este período é vivido, porém, depende das aquisições anteriores, pois ela é a culminação de um processo que se iniciou no nascimento, onde ocorre a revivescência dos conflitos inerentes a toda a história do indivíduo, assim, eles se tornam mais ou menos desestruturantes de acordo com a história pregressa da pessoa. Considerando as vivências desses adolescentes, podemos pensar que eles chegam a este momento sem condições psíquicas ou suporte ambiental para lidar com as tarefas concernentes a este período, pois, não lhes foi dada a possibilidade de constituição de um aparato psíquico que os equipasse para lidar com as adversidade da vida. 


\section{6 - CONCLUSÕES}

Concluímos que o Psicodiagnóstico Compreensivo , bem como, a compreensão psicanalítica utilizada, nos possibilitou a realização de diversas inferências teóricas acerca de cada caso, bem como sobre características comuns destes e sobre a questão da infração na adolescência.

Do ponto de vista individual foi possível, dentro de um curto espaço de tempo, uma compreensão profunda e globalizada de cada caso, que nos trouxe a possibilidade de inferir sobre um possível prognóstico e estabelecimento de estratégias de ação.

Desde que bem instrumentalizado, pode ser um recurso útil para auxiliar na condução terapêutica em diversos âmbitos, bem como auxiliar em decisões sobre a condução de medidas sócio-educativas , pois, apesar de nestes estudo termos utilizado esse referencial com adolescentes que se encontravam em medida de Liberdade Assistida , 
como estratégia de inclusão em acompanhamento psicoterapêutico, não nos parece um recurso restrito a esta situação, podendo ser utilizado em diversas condições.

Percebemos a necessidade de abandonar uma postura que ressalte, apenas, os aspectos patológicos da personalidade; assim, buscamos elucidar aspectos sadios no sentido de estabelecer estratégias de ação voltadas para as potencialidade que devem ser desenvolvidas e valorizadas. Ainda, a necessidade de tratar os dados obtidos de forma globalizada e compreensiva, evitando rótulos , compreendendo o indivíduo de forma contextualizada, situando o ato infracional em sua história e enxergando este de forma singularizada , sem reduzir o sujeito ao ato para , assim, podermos conquistar a inclusão do adolescente na sociedade e não a exclusão desta.

Avaliamos que houve uma evolução no que tange ao atendimento ao adolescente infrator no Brasil , porém nada se tem feito para que ele não chegue a infracionar. No âmbito da prevenção, há muito trabalho a ser feito no sentido de garantir às famílias condições para gerir seus conflitos e lhes assegurar as condições básicas para que recebam seus filhos em um ambiente mais saudável.

Uma intervenção em massa se faz necessária, no sentido de proporcionar condições sociais, econômicas, culturais e ideológicas adequadas para um desenvolvimento adequado de nossas crianças e jovens, bem como a inserção salutar destes na vida adulta, oferecendo-lhes perspectivas e expectativas futuras.

No âmbito do tratamento, é fundamental oferecer a estes adolescentes cuidados específicos que permitam o apoio ambiental que não lhes foi oferecido outrora, associandose recursos terapêuticos ao oferecimento de um ambiente estável e a modelos identificatórios e relacionais adequados. 
Este trabalho lança bases para diversas reflexões teóricas e futuras pesquisas, e esperamos que elas aconteçam e, assim, continuemos a nos responsabilizar pela questão.

\section{7 - ANEXOS}

\section{(Anexo 1)}

\subsection{PARTICIPAÇÃO EM PESQUISA}

Informação ao cliente

Título da Pesquisa:

Adolescentes Infratores : Um Estudo Compreensivo

Objetivos da Pesquisa:

Buscar a Compreensão sobre aspectos do funcionamento da personalidade de adolescentes que cometeram ato infracional, para respaldar estratégias de ação.

No que consistirá à participação do cliente:

Participar de um estudo onde serão realizadas entrevistas, Desenhos - Estórias, Desiderativo, Entrevista com Família e Devolutiva.

Tipos de registro que serão utilizados:

Escrito

Como serão os esclarecimentos sobre os resultado:

Será realizada entrevista devolutiva

Nome do Pesquisador:

Danuza Sgobbi Saes 
Observação: O cliente poderá desistir da participação em qualquer etapa da pesquisa ou esclarecer qualquer dúvida que possua sobre sua participação diretamente com a pesquisadora no fone xxxxxxx ou xxxxxxx.

\section{(Anexo 2)}

\subsection{Participação em Pesquisa}

Termo de Ciência / Anuência do cliente

Título da Pesquisa:

Adolescentes Infratores:Um Estudo Compreensivo

Esclarecimentos Adicionais:

As informações prestadas pelo cliente através desta pesquisa poderão ser utilizadas para fins didáticos e para publicações científicas. Essas informações serão tratadas de forma confidencial e os dados de identificação dos clientes não serão divulgados.

O cliente pode desistir de sua participação em qualquer momento do processo , sem necessidade de justificar sua decisão.

Nome do cliente:

Idade

Nome do Responsável: .Idade

RG:

Declaro que de livre e espontânea vontade aceito participar da pesquisa nas condições acima.

São Paulo, de 200. 
Assinatura

(Anexo 3)

\subsection{Termo de anuência e autorização.}

$\mathrm{Eu}$, possuidor

(a) 0 cargo de

Instituição.................................................................. autorizo a psicóloga e pesquisadora Danuza Sgobbi Saes a realizar pesquisa nesta Instituição, utilizando- se, para tanto, das dependências e da população desta e divulgando o nome desta.

Comprometendo-se esta pesquisadora, porém, que seu trabalho não alterará a dinâmica de trabalho desta instituição, de outros profissionais ou da população a ser atendida.

Que os dados que possam identificar os sujeitos participantes da pesquisa serão excluídos, bem como, como qualquer dado sobre a rotina desta Instituição. E que esta pesquisa será utilizada, exclusivamente, para fins de publicação e estudos acadêmicos e científicos. 
Diante destes termos, subscrevo-me: 


\section{Tabelas:}

\section{1 - Tabela do perfil do adolescentes atendidos no Ministério Público de São Paulo no período de Julho 1998 a Junho 2001.}

\begin{tabular}{|c|c|c|c|c|c|c|c|c|c|}
\hline & & \multicolumn{2}{|c|}{ jul/98 á jun/99 } & \multicolumn{2}{|c|}{ jul/99 á jun/00 } & \multicolumn{2}{|c|}{ jul/00 á jun/01 } & \multicolumn{2}{|c|}{ Média Total } \\
\hline \multicolumn{2}{|c|}{ Dados Cadastrados } & 13542 & $100 \%$ & 13277 & $100 \%$ & 10887 & $100 \%$ & 12569 & $100 \%$ \\
\hline \multirow{2}{*}{ Sexo } & Masc. & 12289 & $100,00 \%$ & 11935 & $100,00 \%$ & 9784 & $100,00 \%$ & 11336 & $100,00 \%$ \\
\hline & Fem. & 1253 & $10,20 \%$ & 1342 & $11,24 \%$ & 1103 & $11,27 \%$ & 1233 & $10,87 \%$ \\
\hline \multirow{3}{*}{ Cor } & Branca & 8064 & $65,62 \%$ & 7713 & $64,63 \%$ & 6625 & $67,71 \%$ & 7467 & $65,87 \%$ \\
\hline & Parda & 2637 & $21,46 \%$ & 3351 & $28,08 \%$ & 2566 & $26,23 \%$ & 2851 & $25,15 \%$ \\
\hline & Negra & 2841 & $23,12 \%$ & 2213 & $18,54 \%$ & 1696 & $17,33 \%$ & 2250 & $19,85 \%$ \\
\hline \multirow{6}{*}{ Idade } & 12 anos & 370 & $3,01 \%$ & 314 & $2,63 \%$ & 166 & $1,70 \%$ & 283 & $2,50 \%$ \\
\hline & 13 anos & 677 & $5,51 \%$ & 614 & $5,14 \%$ & 347 & $3,55 \%$ & 546 & $4,82 \%$ \\
\hline & 14 anos & 1431 & $11,64 \%$ & 1335 & $11,19 \%$ & 936 & $9,57 \%$ & 1234 & $10,89 \%$ \\
\hline & 15 anos & 2408 & $19,59 \%$ & 2373 & $19,88 \%$ & 1948 & $19,91 \%$ & 2243 & $19,79 \%$ \\
\hline & 16 anos & 3910 & $31,82 \%$ & 3609 & $30,24 \%$ & 3035 & $31,02 \%$ & 3518 & $31,03 \%$ \\
\hline & 17 anos & 4746 & $38,62 \%$ & 5032 & $42,16 \%$ & 4455 & $45,53 \%$ & 4744 & $41,85 \%$ \\
\hline \multirow{2}{*}{ Naturalidade } & São Paulo & 12002 & $97,66 \%$ & 11720 & $98,20 \%$ & 9589 & $98,01 \%$ & 11104 & $97,95 \%$ \\
\hline & Outros Estados & 1540 & $12,53 \%$ & 1557 & $13,05 \%$ & 1298 & $13,27 \%$ & 1465 & $12,92 \%$ \\
\hline \multirow{3}{*}{ Tipo de Habitação } & Própria & 10379 & $84,46 \%$ & 10236 & $85,76 \%$ & 8227 & $84,09 \%$ & 9614 & $84,81 \%$ \\
\hline & Alugada & 2619 & $21,31 \%$ & 2783 & $23,32 \%$ & 2448 & $25,02 \%$ & 2617 & $23,08 \%$ \\
\hline & Rua & 544 & $4,43 \%$ & 258 & $2,16 \%$ & 212 & $2,17 \%$ & 338 & $2,98 \%$ \\
\hline \multirow{3}{*}{ Renda Familiar } & 0 a 3 salários mínimos & 5071 & $41,26 \%$ & 6058 & $50,76 \%$ & 5582 & $57,05 \%$ & 5570 & $49,14 \%$ \\
\hline & 4 a 6 salários mínimos & 4257 & $34,64 \%$ & 4584 & $38,41 \%$ & 3740 & $38,23 \%$ & 4194 & $36,99 \%$ \\
\hline & acima de 6 salários mínimos & 4214 & $34,29 \%$ & 2635 & $22,08 \%$ & 1565 & $16,00 \%$ & 2805 & $24,74 \%$ \\
\hline \multirow{2}{*}{ Estuda Atualmente? } & Sim & 7300 & $59,40 \%$ & 7676 & $64,32 \%$ & 5675 & $58,00 \%$ & 6884 & $60,72 \%$ \\
\hline & Não & 6242 & $50,79 \%$ & 5601 & $46,93 \%$ & 5212 & $53,27 \%$ & 5685 & $50,15 \%$ \\
\hline \multirow{3}{*}{ Instrução } & $1^{\mathrm{a}} \mathrm{a} 4^{\mathrm{a}}$ série & 3115 & $25,35 \%$ & 2863 & $23,99 \%$ & 2209 & $22,58 \%$ & 2729 & $24,07 \%$ \\
\hline & $5^{\mathrm{a}}$ a $8^{\mathrm{a}}$ série & 8191 & $66,65 \%$ & 7950 & $66,61 \%$ & 6436 & $65,78 \%$ & 7526 & $66,39 \%$ \\
\hline & $2^{\circ} \mathrm{grau}$ & 2236 & $18,20 \%$ & 2440 & $20,44 \%$ & 2214 & $22,63 \%$ & 2297 & $20,26 \%$ \\
\hline \multirow{2}{*}{ Trabalha? } & Sim & 4082 & $33,22 \%$ & 4884 & $40,92 \%$ & 4063 & $41,53 \%$ & 4343 & $38,31 \%$ \\
\hline & Não & 9460 & $76,98 \%$ & 8393 & $70,32 \%$ & 6824 & $69,75 \%$ & 8226 & $72,56 \%$ \\
\hline \multicolumn{2}{|c|}{ Trabalham registrados? } & 545 & $4,43 \%$ & 467 & $3,91 \%$ & 892 & $9,12 \%$ & 635 & $5,60 \%$ \\
\hline \multicolumn{2}{|c|}{ Não estudam, nem trabalham } & 4428 & $36,03 \%$ & 3663 & $30,69 \%$ & & $0,00 \%$ & 4046 & $35,69 \%$ \\
\hline \multirow{2}{*}{ Declararam usar ou já ter usado drogas } & Sim & 3820 & $31,08 \%$ & 3979 & $33,34 \%$ & 3029 & $30,96 \%$ & 3609 & $31,84 \%$ \\
\hline & Não & 9722 & $79,11 \%$ & 9298 & $77,91 \%$ & 7858 & $80,31 \%$ & 8959 & $79,03 \%$ \\
\hline \multirow{2}{*}{ Reincidentes } & Sim & 3185 & $25,92 \%$ & 2557 & $21,42 \%$ & 1939 & $19,82 \%$ & 2560 & $22,59 \%$ \\
\hline & Não & 10357 & $84,28 \%$ & 10720 & $89,82 \%$ & 8948 & $91,46 \%$ & 10008 & $88,29 \%$ \\
\hline \multicolumn{2}{|c|}{ reinteradas práticas infracionais } & 1549 & $12,60 \%$ & 1182 & $9,90 \%$ & 672 & $6,87 \%$ & 1134 & $10,01 \%$ \\
\hline \multicolumn{2}{|c|}{ Internação Anterior } & 1083 & $8,81 \%$ & 585 & $4,90 \%$ & 290 & $2,96 \%$ & 653 & $5,76 \%$ \\
\hline
\end{tabular}




\section{2 - Tabela de Infrações cometidas pelos adolescentes atendidos no}

Ministério Público de São Paulo no período de Julho 1998 a Junho 2001.

Observação:

Artigo 157 do código Penal: Roubo

Artigo 155 do código Penal: Furto

Artigo 16 do código Penal: Tráfico de Entorpecentes

\begin{tabular}{|l|c|c|}
\hline \multicolumn{3}{|c|}{ ARTIGO 157 } \\
\hline JUL/98 A JUN/99 & $27,46 \%$ & 3719 \\
\hline JUL/99 A JUN/00 & $32,15 \%$ & 4268 \\
\hline JUL/00 A JUN/01 & $32,77 \%$ & 3568 \\
\hline \multicolumn{3}{|c|}{ ARTIGO 155 } \\
\hline JUL/98 A JUN/99 & $14,46 \%$ & 1958 \\
\hline JUL/99 A JUN/00 & $13,65 \%$ & 1812 \\
\hline JUL/00 A JUN/01 & $15,90 \%$ & 1731 \\
\hline \multicolumn{3}{|c|}{ ARTIGO 16 DA LEI 6368/76 } \\
\hline JUL/98 A JUN/99 & $5,77 \%$ & 782 \\
\hline JUL/99 A JUN/00 & $6,37 \%$ & 846 \\
\hline JUL/00 A JUN/01 & $6,60 \%$ & 718 \\
\hline
\end{tabular}




\section{9 - REFERÊNCIA BIBLIOGRÁFICAS}

ABERASTURY, A.; KNOBEL, M. Adolescência normal: um enfoque psicanalítico.

10ª edição, 92 p, Porto Alegre: Artmed Editora, 1981.

ADORNO, S. ; LIMA, R. S.; BORDINI, E. B. T. O adolescente na criminalidade

urbana em São Paulo. Ministério da Justiça, Secretaria de Estado do Direitos Humanos. Brasília: 1999.

ARZENO, M. E. G. Psicodiagnóstico clínico na atualidade: novas contribuições. 245p ,Porto Alegre: Artes Médicas, 1995.

ASSIS, S. G. ; SOUZA, E. G. Caim e Abel: Pensando a Prevenção da Infração

Juvenil. Pesquisa Fundação Osvaldo Cruz, Rio de Janeiro: Ciência e Saúde Coletiva, 4 (1), p.131-144, 1999.

ALVES, S.F.T. Efeitos da internação sobre a psicodinâmica de adolescentes autores de ato infracional. São Paulo, 2001. 230p. Dissertação (Mestrado) - Instituto de Psicologia, Universidade de São Paulo.

; CONSTANTINO, P. Filhas do Mundo : A infração juvenil feminina no Rio de Janeiro. Rio de Janeiro: FIOCRUZ, 2001.

(2002) Crescendo em meio à violência . In Violência e criança.

São Paulo: Edusp. p. 115-124. 
BACHARACH, A. J. Introdução à Pesquisa Psicológica. 4. ed., 107p,

São Paulo: EPU, 1975.

BECKER, D. O que é adolescência? 8. ed., 96pg., São Paulo: Ed. Brasiliense, 1991.

BECKER, S. H. Métodos de Pesquisa em Ciências Sociais. $4^{\mathrm{a}}$ ed., 178p, São Paulo: Ed Hucitec, 1999.

BICUDO, M. A .V.; MARTINS, J. A Pesquisa Qualitativa em Psicologia: Fundamentos e Recursos Básicos. 2 ed., 110p, São Paulo: Ed. Moraes, 1994.

BLAY, E. Adolescência: Uma questão de classe social e gênero. In LEVISKY, David Léo (org.) Adolescência e violência: conseqüências da realidade brasileira. São Paulo: Casa do Psicólogo, 2000.

BLEICHMAR, N.; BLEICHMAR, C.L A Psicanálise depois de Freud: Teoria e Clínica., 453p, Porto Alegre: Ed. Artes Médicas, 1992.

BLEGER, J. Temas de psicologia: Entrevistas e Grupos. 2. ed., 137p, São Paulo: Ed. Martins Fontes, 1998.

BLOS, P. Transição adolescente. 343p, Porto Alegre: Artes Médicas, 1996.

BRANDÃO, J. R. M. Adolescentes Infratores em São Paulo: retrato da exclusão social? Dissertação (Mestrado). Faculdade de Saúde Pública. Universidade de São Paulo, São Paulo, 2000.

BRASIL. Código De Ética Dos Psicólogos. Conselho Regional de Psicologia do Estado de São Paulo, Regional 6. 
BRASIL. Comissão Nacional de Ética em Pesquisa. Normas para pesquisa envolvendo seres humanos. Conselho Nacional de saúde. Brasília, Ministério da Saúde , 2000.

BRASIL. Estatuto da Criança e do Adolescente. Imprensa Oficial, São Paulo, 1998.

BRENNER, C. Noções Básicas de Psicanálise. $3^{\mathrm{a}}$ ed., 260p, Rio de Janeiro: Ed. Imago, 1975.

BRITO, F. B. Ecos da FEBEM : história oral de vida de funcionários da Fundação Estadual de Bem - Estar do menor de São Paulo. Dissertação (Mestrado). Universidade de São Paulo, São Paulo, 2002.

CAMPOS, D. M. S. Psicologia da Adolescência: Normalidade e Psicopatologia.150p, Rio de Janeiro: Editora Vozes, 1990.

CAPITÃO, C. Psicanálise e Ciência: Algumas Considerações. Revista Psico Universidade São Francisco, Bragança Paulista, vol. 4, n. 1, jan./jun,1999.p. 2536.

CARMO, H.M.S. Reflexões sobre psicodiagnóstico: análise crítica de estudos de caso tendo em vista a organização posterior de modelos abreviados de psicodiagnóstico. 1989. 112p. Tese (Doutorado em Psicologia ) - Instituto de Psicologia, Universidade de São Paulo, São Paulo, 2001.

CELENER, G.D. Avaliação Psicológica da Vivência de Desamparo em Adolescentes.1999. 113-134 pp In Rev Mudanças Psicoterapia e Estudos Psicossociais, v 7 jan/jun. 1999.

CHIAPETTI, N. Comportamento de risco em pré-adolescentes institucionalizados. 2001. p.182. Tese (Doutorado em Psicologia) - Instituto de Psicologia, Universidade de São Paulo, São Paulo, 2001. 
BRASIL. Comissão Nacional de Ética em Pesquisa. Normas para pesquisa envolvendo seres humanos. Conselho Nacional de saúde. Brasília, Ministério da Saúde , 2000.

CONTE, F. C. S. Pesquisa e intervenção clínica em comportamento delinqüente numa comunidade pobre. 1996. Tese (Doutorado em Psicologia) - Instituto de Psicologia, Universidade de São Paulo, São Paulo, 1996.

CONSTANTINO, P. Entre as Escolhas e os Riscos Possíveis : A inserção das jovens no tráfico de drogas. Rio de Janeiro: FIOCRUZ, 2001.

COSTA, J. Violência e Psicanálise. 221p, Rio de Janeiro: Editora Graal, 1984.

CUNHA, J.A. Psicodiagnóstico- V . 450p, 5 a ed. Porto Alegre: Ed. Artes Médicas, 2000.

DIAS, E. T. M. Adolescência : entre o passado e o futuro, a experiência. 2001. 200p. Tese (Doutorado em Psicologia) - Instituto de Psicologia, Universidade de São Paulo, São Paulo. 2001.

DUARTE, M. S. C. F. Perfil Psico- Social de Adolescentes Autores de Atos Infracionais do Programa de Liberdade Assistida - PLAC: Uma Contribuição da Enfermagem.1995. Dissertação (Mestrado em Enfermagem), Universidade do Pará, Belém -Pará.1995.

FENICHEL, O. Teoria Psicanalítica das Neuroses. 5a ed., 883p, Livraria Atheneu. Rio de Janeiro: 1981. 
FIGUEIREDO, L.C. Revisitando as Psicologias: Da epistemologia à ética das Práticas e Discursos Psicológicos . 97p, Ed. Vozes. São Paulo: 1996.

FIRTZ, B. M. Manual de Diagnóstico Diferencial (DSMIV). 263p, Porto Alegre, Ed. Artes Médicas.

FREUD, A. O Ego e os mecanismos de defesa. Trad.: Álvaro Cabral. $2^{\text {a }}$ ed. 149p, Rio de Janeiro. 1972. (Coleção Perspectivas do homem série psicológica, v. 85)

FREUD, S.: O Interesse científico da Psicanálise. (1913), pp 169-190. In Totem e Tabu e Outros Traalhos. Obras Completas, Vol XIII , Editora Imago, Rio de Janeiro, 1996.

Sobre a Psicanálise. (1913), 223-225 pp. In O caso Schereber, arigos sobre a técnica e outros trabalhos. Obras Completas, Vol XII, Editora Imago, Rio de Janeiro, 1996.

Formulações Sobre os Dois Princípios do Funcionamento Mental (1911), 233237pp . Obras Completas, Vol XII, Editora Imago, Rio de Janeiro, 1996.

Psicopatologia da Vida Cotidiana.(1901), 309p Vol. VI Obras Completas, Editora Imago, Rio de Janeiro, 1996.

A Interpretação dos Sonhos.(1900), 362p. Obras Completas, Vol IV e V , Editora Imago, Rio de Janeiro, 1996.

Cinco Lições de Psicanálise.(1910), 17-60pp. Obras Completas, Vol XI, Editora Imago, Rio de Janeiro, 1996. 
Além do Princípio de Prazer. (1920),17-79pp, In Obras Completas, Vol XIII , Editora Imago, Rio de Janeiro, 1996.

O Aparelho Psíquico. Vol. V In Obras Completas. Edição Eletrônica da Editora Imago.

Análise de Uma Fobia em um Menino de Cinco Anos.(1909), 15-133pp, In Obras Completas, Vol X , Editora Imago, Rio de Janeiro, 1996.

O Mal Estar na Civilização(1930).67-73pp In Obras Completas, Vol. XXI , Editora Imago, Rio de Janeiro, 1996.

GABBARD. G.O. Psiquiatria Psicodinâmica: Baseado no DMSV IV. 2a ed. 419p, Porto Alegre, Artes Médicas. 1998.

GALL, N. Desorganização política e problemas de escala são Paulo metrópole. In In LEVISKY, L. Adolescência e violência: ações comunitárias na prevenção. Casa do Psicólogo. São Paulo: 2001.

GRASSANO, E. Indicadores Psicopatológicos nas técnicas projetivas. Trad.: Leila Salomão de La Plata Cury Tardivo. 445p, Casa do Psicólogo. São Paulo: 1996.

GUIRADO, M. Instituição e relações afetivas - um estudo feito na Febem - São Paulo. São Paulo, 1985, 217p. Tese (Doutorado em Psicologia) - Instituto de Psicologia, Universidade de São Paulo, São Paulo,1985.

GRUNSPUM, H. Violência e Resiliência : A criança resiliente na adversidade. Rev Bioética, p. 163-171. 2002. 
GOTLIEB, S. L. D. Crianças, adolescentes e jovens do Brasil no fim do séc XX. In Violência e Criança, p. 45-72. Edusp, São Paulo, 2002.

GUAGLIARDI , E. C. . Um lugar de violência : o lugar da psiquiatria, hegemonia, identidade e prática. Jornal brasileiro de psiquiatria 39 (2) p. 85-90.1990

HINSHELWOOD, R. D. Dicionário do Pensamento Kleiniano. 507p, Porto Alegre: Artes Médicas, 1992.

JAPIASSU, H. Psicanálise : Ciência ou Contraciência. 175p, Rio de Janeiro: Editora Imago, 1989.

JESSÉ, J. Crianças e Adolescentes em Conflito com a Lei. In DINIZ, Andréa; LOBO, Ana Paula. A criança e o adolescente em situação de risco em debate. Litteris - Kroart, p. 107-117. 1998.

KLEIN, M. Tendências Criminais em Crianças Normais, 1927 In Contribuições à Psicanálise, 2ª ed., 470p, Ed. Mestre Jou, São Paulo, 1981.

KLEIN, M. Desenvolvimento inicial da consciência na criança,1933. In Contribuições à Psicanálise, 2ª ed., 470p, Ed. Mestre Jou, São Paulo, 1981.

KLEIN, M. Sobre a Criminalidade. In Contribuições à Psicanálise,1934 In Contribuições à Psicanálise, 2ª ed., 470p, Ed. Mestre Jou, São Paulo, 1981.

KNOBEL, M. Normalidade, responsabilidade e Psicopatologia da violência na adolescência In LEVISKY, LÉO: Adolescência e violência: conseqüências da realidade (org.) brasileira. São Paulo. Casa do psicólogo, 2000. 
KRYNSKI, S. O adolescente e a violência : um processo em busca da identidade. In LEVISKY, LÉO Adolescência e violência: conseqüências da realidade brasileira. São Paulo: Casa do psicólogo, 2000.

LAPLANCHE \& PONTALIS. Vocabulário de Psicanálise. 4a ed., 552p, São Paulo: Martins Fontes, 1999.

LEVISKY, D. L.. Aspectos do Processo de Identificação na Sociedade Contemporânea e suas Relações com a Violência In LEVISKY, LÉO Adolescência e violência: conseqüencias da realidade brasileira. 270p, São Paulo: Casa do psicólogo, 2000.

Adolescência: Reflexões Psicanalíticas. 2a ed.,316p, São Paulo: Casa do Psicólogo, 1998.

.(org.) Adolescência e violência: ações comunitárias na prevenção. 340p, São Paulo: Casa do Psicólogo, 2001.

LODI, J. B. A Entrevista : Teoria e Prática. 7ªd. 176p. São Paulo: Editora Pioneira, 1991.

MADUREIRA, M. D. S. O Ser Adolescente Infrator : Significando a própria existência. 1996. 114p. Dissertação (Mestrado em Enfermagem) Universidade Federal de Minas Gerais. Belo Horizonte, 1996.

MARCILIO, M. L. O jovem infrator e a Febem de São Paulo Historia e atualidade. In LEVISKY, LÉO. Adolescência e violência: ações comunitárias na prevenção. São Paulo. Casa do Psicólogo,2001.

MAZZARO, A. C. Investigação Clínica da Personalidade de Adolescentes Homicidas Através do Procedimento de Desenho - Estória. Dissertação (Mestrado em Psicologia) - Instituto de Psicologia, Universidade de São Paulo, 
São Paulo, 2001.

MELLO, A. C. C. O que é ato infracional? In MELLO, A C. C.: O Jovem e seus direitos . p 122-131. São Paulo: Editora Moderna , 1997.

MENIM , M. S. S. Representações Sociais de Justiça em adolescentes infratores: discutindo novas possibilidades de pesquisa. In Rev : Psicologia : Reflexão e Crítica, 13(1), p 59-71, 2000.

MIRAGLIA, P. R. Rituais de Violência: a FEBEM como espaço do medo em São Paulo. Dissertação (Mestrado em Psicologia) - Instituto de Psicologia, Universidade de São Paulo, São Paulo, 2001.

NASIO, J.D. Introdução às Obras de: Freud, Ferenezi, Groddeck, Klein, $\quad$ Winnicott, Dolto, Lacan. 304p Rio de Janeiro: Editora Zahar, 1995.

NINJAMKIN, G.C. \& BRAUDE, M.G. O Questionário Desiderativo. Trad.: Leila Salomão de La Plata Cury Tardivo. São Paulo: Vetor, 2000.

OCAMPO, M.L.S. Processo Psicodiagnóstico e as técnicas projetivas. Maria Luiza Siquier de Ocampo, Maria Esther Garcia Arzeno, Elza G. de Piccolo. $4^{\mathrm{a}}$ ed., 437p, São Paulo: Martins Fontes, 1981.

OSORIO, L. C. Adolescente hoje. $3^{\mathrm{a}}$ ed. 230p, Porto Alegre: Artmed, 1989.

OUTEIRAL, J. O. Tendência Anti social e Patologia do Espaço Transicional. In LEVISKY, LÉO Adolescência e violência: conseqüências da realidade brasileira. São Paulo: Casa do Psicólogo, 2000. 
PERALVA, A. Violência brasileira : entre crescimento da igualdade e fragilidade institucional. In LEVISKY, LÉO. Adolescência e violência: ações comunitárias na prevenção. São Paulo: Casa do Psicólogo, 2001.

PESSANHA, A.L.S. Adolescência : tanto faz? In LEVISKY, LÉO. Adolescência e violência: ações comunitárias na prevenção. São Paulo: Casa do Psicólogo, 2001.

PIAGET, J. A Construção do Real na Criança. 370p, Rio de Janeiro: Editora Zahar., 1979.

PIGNOT, V. S. Prática de furtos na adolescência : estudo da evolução de dois casos. Jornal Brasileiro de Psiquiatria. p. 193-6 42 (4), 1993

RAPAPORT, D. A Estrutura da Teoria Psicanalítica: Uma tentativa de sistematização. 146p, São Paulo: Perspectiva, 1982.

ROMANO, Roberto. Violência brasileira: entre o privado e o público. In LEVISKY, LÉO. Adolescência e violência: ações comunitárias na prevenção. São Paulo: Casa do Psicólogo, 2001.

SÁ, A.A. Reincidência criminal: sob o enfoque da psicologia clínica preventiva. 121p. São Paulo: EPU, 1987.

Delinquência Juvenil Como Uma das Formas de Solução da Privação Emocional. In Rev. Psicologia : Teoria e Prática, Vol. 3 (jan/jun), 13-21pp, 2001.

SAFRA, G. Momentos Mutativos em Psicanálise: Uma Visão Winnicottiana.213p, São Paulo: Casa do Psicólogo, 1995.

A face Estética do Self: Teoria e Clínica. 168p, São Paulo, Ed. Unimarco, 1999. 
SANTOS , M. C. C. L. Raízes da violência na criança e danos psíquicos. In Violência e Criança. p. 189-204 . São Paulo: Edusp, 2002.

SILVA, Maria Emílio Lino (coord) Investigação e Psicanálise. Campinas: 2a ed. 171p,Ed. Papirus, 1993.

SIMON, R. Introdução à Psicanálise: Melanie Klein. 135p, São Paulo: EPU, 1986.

SHINE, S. K. Psicopatia: clinica psicanalítica . 149p, São Paulo,: Casa do Psicólogo, 2001.

SPITZCOVISKY, J. Os adolescentes, vitimas e personagens de guerras no séc. 21. In LEVISKY, LÉO. Adolescência e violência: ações comunitárias na prevenção. São Paulo: Casa do Psicólogo, 2001.

SOARES. E. S. $O$ ato infracional à luz do estatuto da criança e do adolescente e o poder judiciário- lei n 8.069/90. In LEVISKY, LÉO. Adolescência e violência: ações comunitárias na prevenção. São Paulo: Casa do Psicólogo, 2001.

SOUZA, A. A. G. S. O Judiciário Protege A Crianca E O Adolescente? In LEVISKY, LÉO. Adolescência e violência: ações comunitárias na prevenção. São Paulo: Casa do Psicólogo, 2001.

TARDIVO, L.S.P.C. Normas para Avaliação do D-E numa amostra de crianças paulistanas de 5 a 8 anos de idade. 1985. 294p. Dissertação (Mestrado em Psicologia) - Instituto de Psicologia, Universidade de São Paulo, São Paulo, 1985.

TARDIVO, L.S.P.C. (1997). “Análise e Interpretação”- In: Trinca, W. (org) Formas de Investigação Clínica em Psicologia: O D-E e o Procedimento de Famílias com estórias. São Paulo: Vetor, 1997. 
TRINCA, W. Diagnóstico Psicológico: A Prática Clínica. 106p, Editora São Paulo: EPU, 1984.

O Procedimento de desenhos de família com estórias na investigação da personalidade de crianças e adolescentes. Boletim de Psicologia, 39 (90/91): p.4554, 1989.

TRINCA, W. (org.) Formas de Investigação Clínica em Psicologia. $3^{\mathrm{a}}$ ed, 292p, São Paulo: Vetor, 1997.

TRIVIÑOS, A.N.S. Introdução a Pesquisa em Ciências Sociais. 2ª ed., 175p, São Paulo: Ed. Atlas, 1995.

UCHÔA, D.M. Psicanálise: Teoria e Prática. 126p, São Paulo: Livraria Atheneu, 1984.

VIOLANTE, M.L.V. A perversidade da exclusão social In LEVISKY, LÉO Adolescência e violência: conseqüências da realidade (org.) brasileira. São Paulo: Casa do Psicólogo, 2000.

O Dilema do Decente Malandro: a questão da identidade do Menor FEBEM. 4a ed., 230p, São Paulo: Editora Cortez, 1985.

VOLPI, M. (org.) O Adolescente e o ato infracional. 87p, São Paulo: Editora Cortez,1997.

WINNICOTT, D. W. Da Pediatria à Psicanálise: Obras escolhidas. 340p, Rio de Janeiro: Editora Imago, 2000.

Natureza Humana. 222p, Rio de Janeiro: Editora Imago, 1990. 
O Brincar e a realidade. 203p, Rio de Janeiro: Editora Imago,1975.

Tudo Começa em Casa. 211p, São Paulo: Editora Martins Fontes, 1989.

A Criança e Seu Mundo. 6a ed, 220p, Rio de Janeiro: Editora Zahar, 1975.

Privação e Delinqüência. 290p, São Paulo: Martins Fontes, 1999.

ZIMERMAN, D. E. Fundamentos Psicanalíticos: Teoria, Técnica e Clínica. 320p, Porto Alegre: Editora Artmed, 1999. 

